\title{
Hemodynamic effects of antihypertensive drugs in conscious spontaneously hypertensive rats
}

Citation for published version (APA):

Nievelstein, H. N. M. W. (1987). Hemodynamic effects of antihypertensive drugs in conscious spontaneously hypertensive rats. [Doctoral Thesis, Maastricht University]. Rijksuniversiteit Limburg. https://doi.org/10.26481/dis.19870626hn

Document status and date:

Published: 01/01/1987

DOI:

10.26481/dis.19870626hn

Document Version:

Publisher's PDF, also known as Version of record

\section{Please check the document version of this publication:}

- A submitted manuscript is the version of the article upon submission and before peer-review. There can be important differences between the submitted version and the official published version of record. People interested in the research are advised to contact the author for the final version of the publication, or visit the DOI to the publisher's website.

- The final author version and the galley proof are versions of the publication after peer review.

- The final published version features the final layout of the paper including the volume, issue and page numbers.

Link to publication

\footnotetext{
General rights rights.

- You may freely distribute the URL identifying the publication in the public portal. please follow below link for the End User Agreement:

www.umlib.nl/taverne-license

Take down policy

If you believe that this document breaches copyright please contact us at:

repository@maastrichtuniversity.nl

providing details and we will investigate your claim.
}

Copyright and moral rights for the publications made accessible in the public portal are retained by the authors and/or other copyright owners and it is a condition of accessing publications that users recognise and abide by the legal requirements associated with these

- Users may download and print one copy of any publication from the public portal for the purpose of private study or research.

- You may not further distribute the material or use it for any profit-making activity or commercial gain

If the publication is distributed under the terms of Article $25 \mathrm{fa}$ of the Dutch Copyright Act, indicated by the "Taverne" license above, 
Hemodynamic effects of antihypertensive drugs in conscious spontaneously hypertensive rats 



\section{Hemodynamic effects of antihypertensive drugs in conscious spontaneously hypertensive rats}

Proefschrift

ter verkrijging van de graad van doctor in de Geneeskunde aan de Rijksuniversiteit Limburg te Maastricht, op gezag van de Rector Magnificus, Prof. Dr. F.I.M. Bonke, volgens het besluit van het College van Dekanen, in het openbaar te verdedigen op vrijdag 26 juni 1987 des namiddags om vier uur

door

Hubert Nicolas Maria Willem Nievelstein geboren te Kerkrade

16-7-1954 
Promotor: Prof. dr. H.A.J. Struyker Boudier

Co-promotor: Dr. J.F.M. Smits

Referent: Prof. dr. K.H. Rahn

Referent: Prof. dr. P.A. van Zwieten

This thesis was prepared as part of a ZWO/MEDIGON funded project in the department of Pharmacology (head: prof. dr. H.A.J. Struyker Boudier), section Animal Experimental Pharmacology (section head: dr. J.F.M. Smits), University of Limburg, Maastricht, The Netherlands.

Experimental assistance: C. Tyssen, M. Schaefer, J. Debets, H. van Essen and R. Hornsveld.

The manuscript was typed by E. Geurts and M. Hogenboom.

Graphic advises: M. Uitendaal.

Druk: Groenevelt bv, Landgraaf

Financial support for publication of this thesis by Servier b.v. the Netherlands and Sandoz b.v. the Netherlands.

I express my gratitude to all who have contributed in any way to the realization of this thesis. 
Ornnes enim causae effectuum naturalium dantur per lineas, angulos et figuras. Aliter enim impossibile est scire propter quid in illis.

Uit: Il Nome della Rosa, Umberto Eco

Ter nagedachtenis aan:

Christian Joharnn Doppler (1803-1853) 

TABLE OF CONTENTS

Abbreviations

Chapter 1: General Introduction 11

1.1 Introduction 11

1.2 The role of the kidney in the development of hypertension

1.3 Renal perfuston and sodiun excretion 15

1.4 Vasodilators versus renal vasodilation 17

1.5 Reglonal hemodynamics of antihypertensive drugs with a special emphasis on renal effects 20

1.6 Aim of the present investigations 27

Chapter 2: Materlals and Methods 29

2.1 Animals 29

$\begin{array}{ll}2.2 \text { Catheters and surgery } & 29\end{array}$

2.3 Measurements of central hemodynamics 32

2.4 Measurements of regional blood flows 33

2.5 Baroreceptor denervation $\quad 35$

2.6 Baroreceptor unloading 37

2.7 Plasma renin concentration measurements 37

2.8 Renal hemodynamic measurements 39

2.9 Renal excretory function measurements 40

2.10 Substances used in this thesis 40

2.11 Statistics $\quad 42$

Chapter 3: Effect of baroreflex desactivation on reglonal hemodynamics in consclous normotensive rats 45

3.1 Introduction 45

3.2 Experimental protocols 46

$\begin{array}{lll}3.3 & \text { Results } & 47\end{array}$

3.4 Discussion $\quad 49$

Chapter 4: Hemodynamic effects of hydralazlne and some hydralazlne-like arteriolar vasodilators in the consclous spontaneously hypertensive rat 53 4.1 Introduction 53 
4.2 Experimental protacol 54

4.3 Results 58

4.4 Discussion 63

Chapter 5: Henodynamic effects of calcium entry blockers in consclous spontaneously hypertensive rats 69

5.1 Introduction 69

5.2 Materials and methods 71

5.3 Results $\quad 74$

5.4 Discussion $\quad 83$

Chapter 6: Hemodymamfic effects of the beta-adrenoceptor

blockers propranolol and tertatolol in consclous spontaneously hypertensive rats. 91

6.1 Introduction 91

6.2 Experimental protacol 93

6.3 Results 95

$\begin{array}{ll}6.4 \text { Discussion } & 107\end{array}$

Chapter 7: Hemodynamic effects of the renal vasodilator prodrug CGP 22. 979A and its parent compound CGP 18 137A

in consclous spontaneously hypertensive rats 113

7.1 Introduction 113

7.2 Experimental protacol 114

$\begin{array}{lll}7.3 & \text { Results } & 117\end{array}$

$\begin{array}{ll}7.4 \text { Discussion } & 128\end{array}$

$\begin{array}{ll}\text { Chapter 8: Concluding remarks } & 137\end{array}$

$\begin{array}{ll}\text { Summary } & 143\end{array}$

$\begin{array}{ll}\text { Samenvating } & 147\end{array}$

References 153

$\begin{array}{ll}\text { Currtculum witae } & 163\end{array}$

List of publlcations $\quad 165$ 


\section{ABBREVIATIONS}

Apart from the comonly known, the following abbrevlations are used in this thesis:

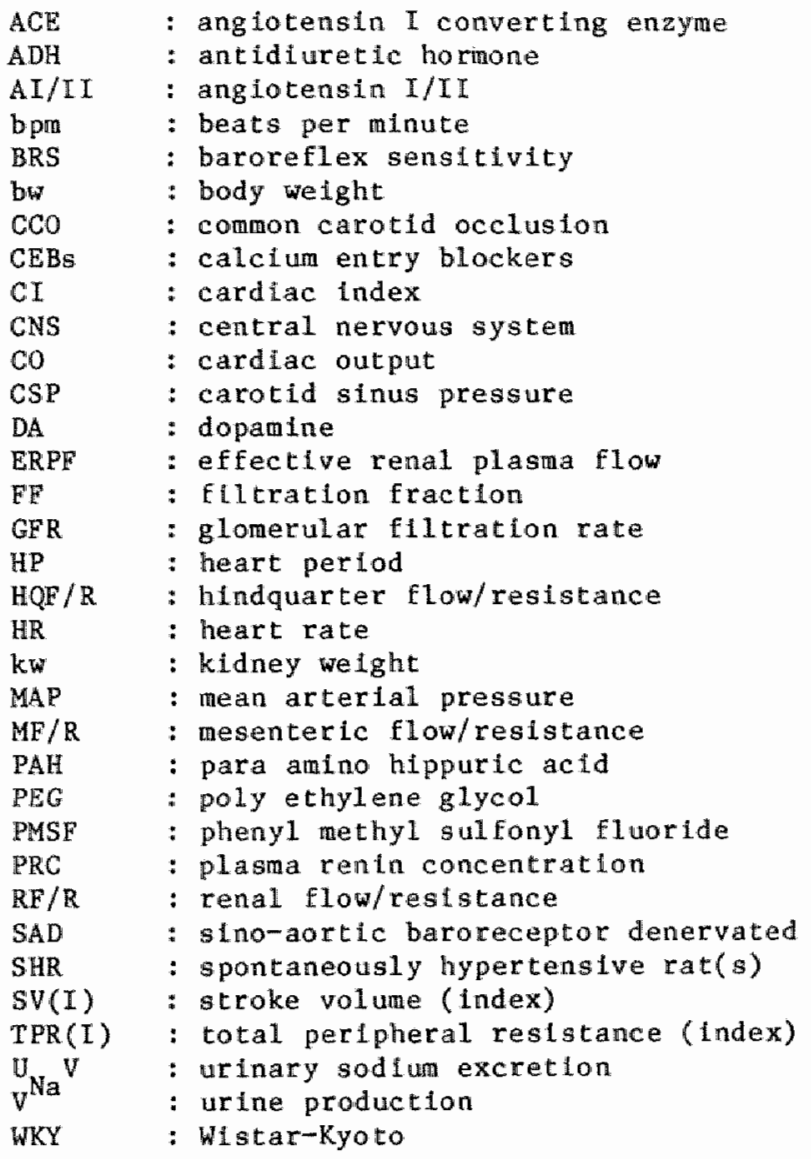





\section{CHAPTER 1}

GENERAL INTRODUCTION

\subsection{Introduction}

Hypertension affects 15-20\% of all adults in western clvilisation. It is an Important risk factor for cardiovascular complications. The major long-term hemodynamic change in essentlal hypertenston is an increase in total peripheral resistance. In the circulation, total peripheral resistance is determined by the resistances of parallel vascular beds:

$$
R=\left(\frac{1}{R_{1}}+\frac{1}{R_{2}}+\frac{1}{R_{3}}\right)^{-1}
$$

in which $R_{1}$, $R_{2}$, etc. each are resistances of individual vascular beds. At the level of a single blood vessel, the resistance can be approximated by Polseulle's law for flow fn a straight tube:

$$
R=\frac{8 \rho L}{\pi r^{4}}
$$

in which $r$ is the radius and $L$ the length of the tube; $\rho$ is the viscoslty of the blood, and $\pi$ is a proportionality constant. For the resistance of a whole vascular bed, the total number of blood vessels is an additional factor of Importance.

It has been suggested that a decrease of the number of perfused blood vessels is a rechanism by which total peripheral resistance can increase in hypercension (Hutchins et al, 1974; Henrich et a1, 1978; revlew Bohlen, 1985b). However, from Polseullie"s law the most 1mportant factor which determines the resistance seems to be the radius of 
the wessel. Most hypotheses on the pathogenesis of hypertension, therefore, focus on a possibly decreased lumen of resistance vessels.

These hypotheses can be distinguished on the basts of factors leading to a decreased lumen. In a first hypothesis, the decrease of the lunen is considered as a prinary mechanism causing hypertension. Several authors have proposed that in this case the decreased lumen of arterloles is the consequence of increased sensitivity of blood vessels to pressor transmitters or hormones (Case et al, 1977; Phillipp et al, 1978; Weber et al, 1981; Johnston et al, 1981; Abboud, 1982) or a deflelency of endogenous vasodilator substances (Lazarus et a1, 1974; McGiff et al, 1981; Furchgott and Zawadzkl, 1980). Other hypotheses explain the decreased lumen as secondary to the hypertension. Folkow (1978) suggested a generallzed wall hypertrophy. A third hypothes ls is the so-called autoregulation concept, originally developed by Borst and Borst-De Geus (1963) and Guyton et al (1972). In that hypothesis, the rise in peripheral resistance is the ultimate consequence of a chain of events - explained in more detall in paragraph 1.2 - that is triggered by a change in the renal excretion of fluid. These different approaches to the mechanism of increased resistance in hypertension have not only important pathogenetic, but also therapeutic implications. The mechanisms whereby an optimal reduction of peripheral resistance 1 s achieved may differ depending upon proposed mechanism. This thesis is an attempt to analyze the regional hemodynamic effects of antihypertensives from this polnt of view. A spectal emphaste wil be given to the third of the above mentioned mechantsms: the long-term elevation of blood pressure and peripheral resistance is the consequence of a renal deficlency in sodium and water excretion. In the rest of this introductory chapter, the role of the kidney in the development of hypertension shall be brlefly discussed flrst. Then, the role of renal perfusion in sodium and water excretion is revlewed. This physiological part will then be followed by an introduction into the regional hemodynamics of antihypertensive drugs with a spectal emphasis on their renal effects. 


\subsection{The role of the kidney in the development of hypertension}

Several investigators have focussed on an important role of the kidney in the intiation of the increase $\mathbb{i n}$ wascular resistance as observed in essential hypertension. Traube (1871) was one of the first investigators who suggested that hypertension might be a consequence of impaired renal excretory function. However, the quantitative importance of renal excretory function in regulating blood pressure remained rather vague until the 1960 s when Borst and Borst-De Geus (1963) began to develop the concept that long-term blood pressure is dictated primarily by renal excretory function. This concept was elaborated by Guyton (1974) who stressed the importance of the relationship beween blood pressure and urine excretion, the so-called renal function curve. Under normal circumstances, a small increase or decrease in blood pressure leads to a large increase or decrease in urine excretion. If for any reason, urine excretion is decreased, blood pressure w111 go up and the increased blood pressure restores urine output at the expense of hypertension. Such a sinift of the renal function curve to a higher blood pressure has indeed been observed in experimental hypertension (Norman et al, 1978; Roman and Cowley, 1985).

Experimental evidence for the involvement of the kldney in the development of hypertension was obtained by several investigators. Bianch1 et al (1973, 1977) and Dah1 and Herne (1973) showed that if kidneys from Milanese and Dahl-hypertensive rats respectlvelly were transplanted into normotensive rats, these latter anfmals developed hypertension even when the transplanted kidneys were from animals of which the blood pressure had not yet increased. Simllar results were observed by Kawabe et al (1978) in spontaneously hypertensive rats.

Several authors have suggested an involvement of the sympathet $1 \mathrm{c}$ nervous system in the change in renal function. Not only do the renal sympathetic nerves control renal vasoconstriction and release of the pressor hormone renin, but also tubular sodtum reabsorption depends upon renal sympathetic nerve activity. Application of noradrenaltne to the perfusate of isolated rat kidneys increases sodium reabsorption when perfusion pressure was held constant (Besarab et $\mathrm{a} 1,1977$ ). 
Furthermore, In isolated proximal tubules of the rat, noradrenaline was able to thulate fluid reabsorption when applied from the peritubulat but not from the luminal side (Bello-Reus, 1980; Chan, 1980). Electrlcal stimulation of renal nerves in anesthetized rats, at an Intensity that does not affect renal blood flow or glomerular filtrathon rate, decreases urinary flow and sodium excretion through an increase in reabsorption at the proximal tubular level (DiBona and Sawin, 1982).

These studtes suggest that renal nerves may be involved in a mechanlsm by which the renal function curve can shift to a higher blood pressure level. In fact, it has been shown that elimination af the sympathetlc innervation of the kidney by surglcal denervation at least retards the development of genetic hypertension (Liard, 1977; Kline et al, 1978; Diz et al, 1982) and DoCA-salt hypertension (Katholi, 1980). Renal denervation also reduces the arterial pressure levels in Goldblatt-hypertensive rats and in dogs (Katholi et al, 1981, 1982). Katholl et al (1981, 1982) suggested from studies in several hypertensive animal models that afferent renal nerves may play an important role in the malntenance of hypertension via a direct feedback mechanlsm influencing efferent sympathetic tone. This effect on efferent sympathetic tone leads then to an increase in vascular resistance, sodium and water retention and renin release.

Borst and Borst-de Geus (1963) and Guyton (1974) suggested that Impairment of renal function is accompanled by sodium and water retention leading to expansion of intravascular volume. This increases cardiac output and causes overperfusion of several tissues. This overperfusion ts then opposed by $10 c a l$ autoregulatory mechanlams which prevent the tissues from further overperfusion by increasing their vascular reststance, and thus increase systemic blood pressure.

Al1 the evidence discussed thus far implies a renal retention of sodium and flutd as a prerequistte for the development of hypertenson. Investigators, however, acknowledge that expansion of fluid volume has not been found in all hypertensive animal models (Haddy et al, 1979).

A more racent hypothests proposes a primary role for a natriuretic hormone which is hypothalamic in origin and is a potent Inhibi- 
tor of the onabain-sensitive $\mathrm{Na}^{+} / \mathrm{K}^{+}$ATPase (De wardener et al, 1981 ; Pamnanil et al, 1981; Huot et all, 1983; liaddy et a1, 1985). Inhibition of the $\mathrm{Na}^{+}$pump leads to an increased intracellular $\mathrm{Na}^{+}$and $\mathrm{Ca}^{2+}$ uptake and thereby increases wascular contractility and reactivity (Blaustein, 1974; De Wardener et al, 1981; Haddy et al, 1985) and hence vascular resistance.

De Wardener et al (1983) and Gruber et al (1980) reported that expansion of fluid volume in dogs Indeed releases a natriuretic hormone. However, Jandhyala and Ansarf (1986) and Beasly and Malvin (1985) have shown that not volume expansion but elevation of cerebrospinal fluid $\mathrm{Na}^{+}$levels triggers the release of a matriuretic hormone, perhaps by activation of $\mathrm{Na}^{+}$sensitive and/or osmosensitive sites. The same stimulus in the CNS releases antidiuretic hormone (ADH). So, a combined renal action of $A D H$ and natriuretic hormone may prevent volume expansion. This suggests that the primary stlmulus for the development of hypertension may be the cerebrospinal flutd $\mathrm{Na}^{+}$levels and not necessarily fluid expansion. Thus far, this natriuretic factor has not been isolated, so its existence is still uncertaln.

In sumary, the above mentioned hypotheses suggest that the primary mechanism which causes hypertenston 1 s a decrease in sodium excretion as a consequence of a renal defect. A causal approach for the treatment of hypertension would, therefore, be an enhancement of the renal capacity to excrete sodlum. Such an approach is avallable since many years in the form of diuretics. These drugs reduce tubular sodium reabsorption and reduce blood pressure. These drugs increase, however, the renin release without tachyphylaxis. This leads to counterregulation of the blood pressure reduction and 1 infts their ant hypertensive ability (Vaughan et al, 1978).

In section 1.3, another posstble way by which an increase in sodtum excretion could be induced, viz. via a change in renal perfusion, is presented.

\subsection{Renal perfusion and sodium excretion}

Total renal sodium excretion is the difference between the 
quantities filtered in the glomeruli and reabsorbed in the tubuli. The glomerular filtration rate is determined by the glomerular and tubular hydrostatlc and the counteracting oncotic pressure, and the capillary flltration coefficient of the glomerulus. In rats the glomerular flow has strong influence on the gloneruliar filtration rate (Marchand and Mohrman, 1980) which is in contrast to the situation in dogs where the effective glomerular flltration pressure strongly influences glomerular filtration rate. This was concluded from micropuncture studies, in which measurements in varlous parts of the nephron showed that there 1s a filtration equllibrlum in the rat (BIantz, 1977; Marchand and Mohrman, 1980) but not in the dog (0tt and Marchand, 1976; Marchand and Mohrman, 1980), 1.e. In the rat the glomerular hydrostatic pressure and oncotic pressure cancel each other somewhere at the glomerular membrane whereas in the $d o g$ oncotic pressure is always lower. From other spectes (tncluding man), these data are not available and it is not known whether there is a filtration equilibrium.

Glomerular blood flow is determined by the blood pressure in the whole arterial circulation and afferent and efferent renal vascular resistance.

Renal vasodilators may dilate afferent and/or efferent arterioles. It depends on where the particular renal vasodilator has its most pronounced effect to what degree GFR may be influenced. However, most substances used so far to cause renal vasodilation (acetylcholine, bradykinin and prostaglandins) increase renal blood flow and sodium excretion without affecting glomerular filtration rate (Marchand et a1, 1977; Hartupee et a1, 1982; Haas et a1,1984; Mertz et al, 1984). These studies indicate that, apart from an increase in GFR, a reducthon In tubular reabsorption of sodlum can be the cause of natriurests after renal vasodilation.

Early and Friedler (1965) and later Fadem et al (1980) postulated that the natriuresis is a consequence of a washout of the solute gradient of the medullary interstitum induced by increased renal plasma flow. However, Hartupee et al (1982) showed that a medullary gradient washout was not accompanied by a natriuresis when renal interstitial hydrostatic pressure was controlled. These results suggest that an increase In renal interstitial hydrostatic pressure is an 
essential component of the natriuresis assoclated with renal vasodilation. Marchand et a1 (1977), Hartupee et al (1982), Has et al (1984), and Mertz et al (1984) also measured peritubular capillary hydrostatic pressure. They observed an increase in peritubular capillary pressure upon renal vasadilation. Marchand et al (1977) compared the effects of the renal vasodilators secretin and acetylcholine on renal interstitial hydrostatic pressure and sodlum excretion in dogs. Whereas both vasodilators increased renal bllood flow and perltubular capillary hydrostatic pressure similarly, only acetylcholine Increased interstitial hydrostatic pressure and sodium excretion. Haas et al (1984) compared the effects of intrarenal infusion of prostaglandins on sodtum excretion. They showed that when renal interstitial hydrostatic pressure was allowed to increase during infusion of prostaglandin $E_{2}$ there was a marked increase in fractional excretion of sodium. However, when the rise in renal interstitial hydrostatic pressure was prevented by prior renal decapsulation and a silght reduction in renal perfusion pressure via aortlc constriction the natriuresis was markedly attenuated despite simflar increases in renal blood flow. Similar results were observed by Hartupee et al (1982). Taken together these studies suggest that renal interstittal hydrostatic pressure is the cruclal factor linking renal hemodynamics to sodium excretion.

In conclusion, the above mentioned observations suggest that selective renal vasodilation could be a way to increase sodium excretion by reducing tubular sodium reabsorption without inhlbiting the $\mathrm{Na}^{+} / \mathrm{K}^{+}$pump. The mechantsm by whtch the renal vasodilators Induce natriuresis is not clear. However, an increase in interstitlal hydrostatic pressure seems to be essential.

\subsection{Vasodilators versus renal vasodilation}

The primary pharmacological effect of arteriolar vasodilators is a relaxation of vascular smooth muscle. This leads to a fall in peripheral resistance and blood pressure. This causes an increase of venous return, and a baroreflex-mediated increase in heart rate and 
cardac output. A second relatively rapild response to vasodilator therapy is an increage in renin release. This rise in renin release is caused by the increased ayapathetlc discharge to the kidney and reduced renal perfusion pressure. A third physlological response to vasodilator therapy is the retention of sodiun and water due to the decreased renal perfuston pressure and increased renin activity. This retention of sodfum and water causes an expansion of extracellular and blood volume.

In pharmacotherapy, most directly acting vasodilators are usual1y glven as a third step after beta-adrenoceptor blocking drugs and/or diuretics which is related to the above mentioned less favorable actlons, durlng single use of these drugs. (Koch-Weser, 1974 ; Gross, 1977 ).

Computer stmulation of an arterlolar vasodilation, using the mathematical model of the cardlovascular system prevlously published by Guyton et al (1972) predicts short-term changes quite slmilar to those observed experimentally (Struyker Boud1er, 1980), e.g* a rapid fall in total peripheral resistance, arterial pressure and urinary excretion rate, an early increase in sympathetic nerve activity, cardiac output and extracellular flufd volume. Moreover, the simulation predicts that long-term effects include a continuous reduction of blood pressure and total peripheral resistance and normalization of sympathetic nerve activity and urinary excretion rate, whereas cardiac output and extracellular fluid volume remain elevated.

Simllar computer slmulation studies (Struyker Doudier, 1980) predlct that a drug with preferentlal renal vasodilating properties could be a candidate for an optimal treatment of hypertension. Fig. 1.1 shows a simulation of the effects of a drug dilating the afferent (preglomerular) artertoles of the kidney starting at the point indicated by the arrow. The results of the simulation Indicate an lmmediate rapid diurests leading to a sight reduction of extracellular and blood volume as well as a slight decrease in cardiac output. In the course of several days, blood pressure drops gradually below predrug level. This reduction in blood pressure is parallelled by a gradual drop in total peripheral resistance, a restoration of cardiac output, excretion of water and salt and blood volume to values close 
to their predrug levels. Extracellular fluid volume remains slightly diminished. Sympathetic nerve activity is elevated to slight degree during the first few days of renal vasodilator therapy but returas to nortwal values shortly thereafter. Moreover, the activity of the reninangiotensin-aldosteron system is not influenced signiflcantly durfing the chronic phase of renal vasodilation therapy.

These simulated effects of a preferential renal vasodilation can be explained by reversing the hypothes 1 s of Borst and Borst-De Geus

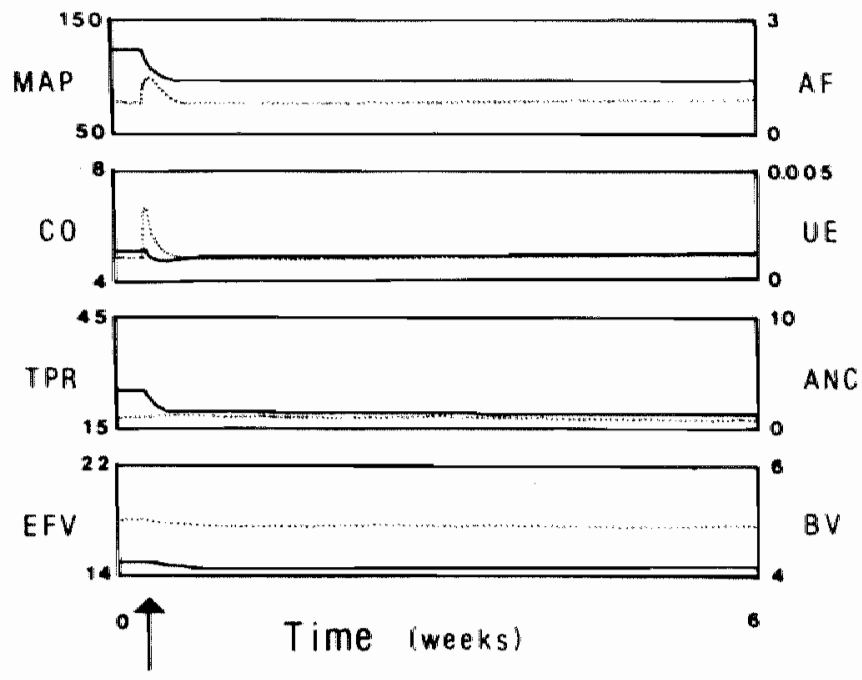

Fig. 1.1: Computer simulation of the effects of a selective renal vasodilator in a hypertensive patient. At the point indicated by the arrow, the resistance of the afferent (preglonemularl artemioles of the kidney was reduced. The bolid lines correspond to parcometere on the left aide of each panal; the dotted lines to parameters on the right. The total duration of the simulation periad was tix weeks. MAP: mean artemial blood preseure (mm $\mathrm{Hg})$; $\mathrm{CO}$ : candiac output (l/min); TPR: totä periphemal reaistance (mm $H g / l / m i n) ;$ EEV: extracelluzar flutd volume (l); $A E$ : autonomia factor, i.e. overall activity of the autonomic nervous aystem r ratio to a normal value of 1: an inoreace from 1 represents an increabe in sympathetio activity or a deameare in parasmpathetic activity); UE: urine excretion (1/min); ANC: melative angiotensin concentration in plabma (ratio to nomal value of 1); BV: blood volime (i). 
(1963) and Guyton (1974) for the development of hypertension. The renal rasodilation 19 accompanied by sodium and water excretion leading to a reduction of intravascular blood volume and extracellular fluld volume. This decreases cardlac output and perfusion of several thssues. This reduced perfusion is then opposed by local autoregulatory mechanlsms which prevent the tissue from further underperfusiom by decreasing thelr vascular reslstance and thus blood pressure. This reduction in wascular reslstance leads then to an increase in venous return which consequently increases cardiac output close to normal. The decreased blood pressure restores urine output at a lower blood pressure. So, the result would be a shifting of the kidney function curve to a lower blood pressure.

The results of the computer sinulation suggest that the reduction of blood pressure is achleved with a minimum of disturbances of other hemodynamics and endocrine parameters, except for total peripheral reststance which drops in parallel to the fall in blood pressure suggesting that renal vasodilation is an optimal therapy for the treatment of hypertension.

The above presented hypothesis has so far not been investigated expertmentally. Thus the question is raised whether there are substances with a preferential renal vasodilation and whether they $1 n-$ crease sodium and water excretion. In the next part of this chapter the effects of several anthypertensives on renal vascular resistance and sodlum and water excretion shall be revlewed.

\subsection{Reglonal hemodynanics of antlhypertensive drugs with a spectal emphas is on renal effects}

In this section, the reglonal hemodynanics of several antihypertensive agents shall be reviewed with a special emphasis on the effects on renal vascular reslstance and sodlum and water excretion.

\subsubsection{Directly acting vasodilators}

The effects of different directly acting vasodilators on renal blood flow and vascular resistance have been assessed in clinical research usting clearance techniques. Hydralazine causes increased 
renal blood flow unilke minoxidil or diazoxide (Reubi, 1950; Johnson, 1971; Zins, 1974; Lefter et a1, 1981). Also in consclous dogs Chelly et al (1986) observed a preferential renal wasodilation after hydralazine. However, Bolt and Saxena (1984) found a more general vasodilation in hypertensive rabbits after hydralazine. They observed not only a reduction in vascular resistance in the kidney but also ln other vascular beds, e.g. heart, brain, and large intestine, after a single dose of hydralazine.

When comparing the above described regional hemodynamic effects with those in the studies of Gottlieb et al (1972) and Hanamer et al (1971) it seems unlikely that directly acting vasodilators preferentlally dilate the renal vascular bed since they cause a retention of sodium and water and an increase in rentn release from the kidney (Gross, 1977). The general vasodilation strongly reduces systemlc blood pressure and consequently renal perfusion pressure. This decrease in renal perfusion pressure may then be responsible for the observed sodium and water retention and the increase in renia release.

\subsubsection{Calcium entry blackers}

of the avallable studies, only a few show renal vasodilating properties of calcium entry blockers (CEBs). Drextler et al (1985) and Kanda and Flaim (1984) found a reduction in renal reslstance in conscious normotensive rats after a single dose of different CEBs. However, this was not a preferential renal vasodilation. These investigators observed also a reduction in vascular resistance in other vascular beds. Drextler et al (1985) found that nisoldiplne also reduces coronary and skeletal muscle vascular resistance. Kanda and Elain (1984) reported a reduction of resistance ta coronary, skeletal muscle and mesenteric vascular beds after nifedipine.

In other regional hemodynamic studies, no renal vasodilation was Found following CEBs in several spectes. Flatm and Zel1s (1982) showed that diltiazen reduces resistance in muscular, coronary, gastrolntestinal and cerebral vascular beds in normotensive consclous rats. Skin and kidney did not dilate. Reed and Tuma (1986) observed for nlfedipine in anesthetized normotensive rats a general vasodilation with a most pronounced effect in skeletal muscle. Sesoko et al (1984) repor- 
ted that nitrendplue as potent as a vasodilator in most organs except skln and skeletal wasle in normotensive conscious rats. In anesthet zed cats, most $C E B s$ reduce vascular resistance in the muscular bed (Hof et a1, 1982). Howewer, this effect was more pronounced after the dihydropyridine derivatives nifediplne, nicardiplne and $\mathrm{PY}$ 108-068 than after verapamil or d11tizem. Hof and co-workers (1983) also observed a conslstent reduction in cerebral and coronary resistance whereas skin and renal resistances remained unchanged in normotensive anesthetized rats. The effects on the gastro-intestinall bed were more varlable showing a vasodilation after nicardipine and diltlazem and little effect following verapanil and PY 108-068 (Hof, 1.983).

In most of the above mentioned reglomal hemodynamic studies flow changes were measured in normotenslve animals using the microsphere technique. However, the directlonal pulsed Doppler system was used by Barron et al (1983) and knight et al (1984) to measure regional hemodynamic effects of CEBs in normotensive consclous rats. Barron et al (1983) found that skeletal muscle and, to a lesser degree, mesenterlc reslstances decreased following nitrendiplne, nisoldiplne and verapam11. No effect on renal reststance was observed. Knight et al (1984) found a pronounced reduction in vascular resistance in the muscular and mesenterlc vascular bed but only a slight reduction in renal resistance.

Taken together, these regional hemodynamic studies suggest that the muscular vascular bed is the preferential site of action for CEBs followed by the coronary and cerebral vascular bed. In other beds, the vascular effects of CBBs are more divergent.

On the basis of the more general vasodilating action of CEBs one would expect a sodium and water retention as a consequence of the rediced renal perfusion pressure. Leonett at al (1982) reported that ntfediplne induced a marked increase in urine volume and sodium excretion in hypertensive patlents with a much smaller change in normotensives. Verapamil did not influence water and sodium excretion in elther direction. Yokoyama et al (1983) found increases in urinary volume and sodfun excretion after nifedipine treatment in patients with essential hypertension. Nordlander et al (1985) observed in 
hypertensive rats an increase in sodium and water excretion after nifediplne and felodipine. Also, nicardipine (Chaignon et al , 1986) and nitrendipine (personal commulcation, Van zwieten) cause natriuresis in man. In view of the lack of a renal vasodilator effect of CEBs the most likely explanation for this diuretic and natriuretic action is a tubular mechanism either directly or indirectly through an effect on aldosteron (Loutzenhiser et $\mathbf{a} 1,1985$ ).

\subsubsection{Beta-blockers}

The acute hemodynamic effects of nost beta-blockers in hypertensive patients or animals consist of a fall in cardiac output whereas a rise in total peripheral resistance prevents an early fall in blood pressure (Ulrych et al, 1968; Tarazi and Dustan, 1972; Sutts et al, 1982; Van Baak et a1, 1982; Cofler et al, 1984). Little is known about the regional vascular beds involved in this total peripheral resistance increase.

Hatzintkolaou et al (1983) found an increase in resistance in most vascular beds after propranolol in normotensive wistar rats using the microsphere method. However, in brain and muscle, wascular resistance was not significantly affected. Van Boom and Saxena (1983) observed an increase in heart, brain, stomach, mesenteric, pancreas, spleen, and skin vascular reststance after propranolol infusion in normotensive rabbits. In renal hypertensive rabbits these investigators found an Increase in vascular reststance only in heart and pancreas after propranolol. On the other hand, N1es et a1 (1973) found a generalized increase in reststance in all vascular beds studled using a propranolol infusion in consclous normotensive monkeys.

These reglonal hemodynamlc studles showed a very divergent pattern during acute beta-blockade wh respect to the renal effects. However, in renal hemodynamic studies in dogs (Nies et al, 1971; Nomura et al, 1978), SHR (Smits et a1, 1982) and hypertenslve man (Weber and Drayer, 1980; Wilkinson, 1982; Epstein and Oster, 1982; Bernstein and O"Connor, 1984) all classes of beta-blockers cause a reduction in renal plasma flow with the exception of nadolol (Duchin et al, 1978; Hollenberg, 1979; Epstein and Oster, 1982) and tertatolol (Laubie et a1, 1986; Palllard et al, 1986). 
In contrast to the renal flow reduction seen in most studies after beta-blockade, several studies showed an lamediate short lasting diurests and natriuresis for different spectes following propranolol (Epsteln and Oster, 1982; Carrara and Balnes, 1976; Shibouta et al, 1979; Smits et $\mathbb{A l}_{1}$, 1982). Metoprolol also causes this effect which makes it likely that the phenomenon is related to beta 1 -receptor blockade (Wikstrand, 1983). Smits et al (1982) have suggested that beta-blocker-medlated diuretic and natriuretic effects in the SHR are caused by a tubular action of beta-blockers.

The most direct way in which beta-blockers may interact with renal tubular processes is through interference with sympathetic innervation of these structures. Radioligand binding studies $\mathbb{i n}$ the rat (Gavendo et a1, 1980; Perrot et al, 1984; Struyker Boudier et al, 1986) have shown the existence of beta ${ }_{1}$-adrenoceptors in tubular fractions of kidney homogenates. Functional evidence for the involvement of tubular beta-receptors in the regulation of sodium excretion cones from studies in which lsolated kidneys (Besarab et a1, 1977) or tubules (Bello Reus, 1980) were perfused. In these studles, noradrenaline caused a reduction of sodium fluxes, whereas this effect could be inhibited by propranolol. These experlments suggest that betablockers may directly interact with tubular function. This causes an effect which cancels the expected water and sodium retention as a consequence of the reduced renal perfusion.

\subsubsection{Anglotensin I converting enzyme Inhtbitors}

A possible preferential renal vasiodilator activity of anglotensin I converting enzyme (ACG) inhibitors has been described in hypertenslve patients (Wong et al, 1981), normotensive and renal hypertenslve dogs (Zlmmerman et al, 1980; Oliver et al, 1983) and spontaneous1y hypertens 1we rats (R1cher et al, 1983; Smits and Struyker Boudier, 1984). It 1s not clear whether the reduction of formation of anglotensin II is solely responsible for the decrease in resistance because the ACE inthibitor captopril also has an antihypertensive effect in patients with low plastha renin levels (Schalekamp, 1984; Man in 't veld et al, 1980). There is evidence that prostaglandins may be involved in captopril's antihypertensive effect because increased levels of 
plasma and urinary metabolites of prostacyclin have been detected and furthermore no antihypertensive effect of captopril was observed after prostacyclin synthesis inhlbition (Mimran et al, 1980; Fouad et al, 1980; Swartz et al, 1980; Goldstone et al, 1981; Hornyeh et a 1, 1982). Another possibility could be an involvement of bradykinin. ACE is identical to kininase II which is responstble for the degradation of bradykinin, a potent vasodllator. So inhibtion of this enzyme may increase plasma bradykinin and induce vasodilation.

It is not yet clear why ACE inhibition is associated with a preferential renal vasodilator effect. Possibly there are differences In the degree of local $\mathrm{ACE}$ inhibition in different tissues (Cohen et a1, 1982, 1983) or these drugs are bound to renal tissue more than elsewhere in the body (Drummer et al, 1983).

Several studies have shown that captopril and enalapril 1 ncrease or have no effect on sodlum and water excretion, whereas a blood pressure reduction is observed (Zimmerman et al, 1980; Wong et a1, 1981; DeBruyn et a1, 1981; Hollenberg, 1982; 01iver et a1, 1983; Smits and Struyker Boudier, 1984). Some of these investigators suggested that the reduction in anglotensin II and aldosteron formation causes these renal excretory effects and not the marked renal vasodilator effect of captopril and enalapril.

\subsubsection{Prostaglandins}

Several naturally occurring prostaglandins, e.g. $P G E_{2}$ and $P G I_{2}$ (prostacyclin) are well known for their renal vasodllator effect upon renal administration (Strandhoy et all, 1974; Hockel and Cowley, 1979; Bear and McGiff, 1979; Imanlshi et al, 1980). Blatne et all (1982) described the synthesis of an orally active prostaglandin analogue $4-(3-(3-(2-(1-$ hyd roxycyclohexy 1$)$ ethy 1$)-4$-oxo-2-thlazol id lny 1$)$ propy 1$)$ benzolc actd. They showed that in consclous dogs with chronically implanted electromagnetic flow probes, oral administration of this agent causes a dose-dependent increase in renal but not in lower aortic blood flow. No natriuresis was obserwed in this study.

Several studies showed that prostaglandins influence renal excretory function. When intrarenal infusion of prostaglandin $\mathrm{E}_{2}$ was performed in anesthetized dogs, Johnston et al (1967) noted that urine 
volume, urlne sodlum excretion, free water clearance and renal plasma flow increased. In this study, glomerular filtration rate and mean arterlal pressure remalned unchanged. Simllar changes following $\mathrm{PGE}_{2}$ infusion have been observed by Martinez-Maldonado et al (1972), Gross et al (1973), Strandhoy et al (1974) and Arendshorst et al (1974). Haas et al (1982) observed an increase in sodiun excretion after $P_{2}$ In rats. Hockel and Cowley (1979) observed in dogs during long-term intra-renal $\mathrm{PGE}_{2}$ infusion a chronic diuresis whereas sodium excretion was only increased during the first hours. They also obserwed a $10-$ fold elevation in plasma renin activity. Studies performed by Yun et a1 (1977) and Gerber et al (1978) Indlcated that Increases in plasma renin activity may be induced by a direct prostaglandin effect on the juxtaglonerular cells.

\subsubsection{Dopamine}

Another group of potential renoselective vasodilators are the dopanine analogs. Studies by Goldberg et al (1978) lindicate the presence of dopamine receptors in the renal vasculature, stimulation of whlch causes renal vasodilation. On the basis of this observation a number of dopamine analogs have been tested for their renal vasodilator potential (Pendleton et al, 1978; Hahn et al, 1982; Ackerman et a1, 1983).

Goldberg and Kohli (1979, 1983) have proposed a classification of dopamine receptors into $\mathrm{DA}_{1}$ and $\mathrm{DA}_{2}$ receptors. The $\mathrm{DA}_{1}$ receptor is mogtly located on vascular smooth muscles in the kidney, whereas $\mathrm{DA}_{2}$ receptor are located on sympathetic nerve terminals and autonomic ganglia (Struyker Boudier, 1986).

Antihypertenstve properties of the dopamine $\mathrm{DA}_{1}$ receptor agonist fenoldopam have been described in both experimental animals (Ackerman et a1, 1982; Berkowltz and Ohlstein, 1984) and humans (Ventura et al, 1984; Redman et a1, 1985; Cregeen et a1, 1985). It was clalmed In1tially that fenoldopam due to its predorinant $D A_{1}$ activity would be a rasodllator with selectivity for the kidney (Ackerman et al, 1982). Later studies have indicated that 1 is is a more general vasodilator (Ackerman et al, 1983; Lappe et al, 1984; Redman et a1, 1985).

Dopamine causes dituresis and natrluresis in different mamalian 
specles independent of 1 ts renal hemodynamic effects. A tubular site of action seems responsible for this dopamine effect (Goto et al, 1979; Wassermann et al, 1980). Ackerman et al (1983) found also for fenoldopam a natriuretic activity in different species.

\subsubsection{Alternative approaches}

The above mentioned preferential renal vasodilation results from pharmacodynamic selectivity of the substances. Another posstble design of drugs with preferential real vasodilator activity based on a selective kinetic action could be the development of renal prodrugs. A prodrug is an agent that is biologically inactive in 1 tself, but contains an active drug that is formed only after metabollc conversion. By using enzymatic routes, spectfic for a certaln organ, one can achieve site-selectlve formation of the active drug ( Smits and Thijssen, 1986). This princtple has already been used successfully in the design of selective dopamine formation from gamaglutamyl-L-dopa in the treatment of acute renal fallure In rats (Casson et a1, 1983). Hofbauer et al (1985) reported the pharmacology of the renal prodrug CGP $22979 \mathrm{~A}$ and its active compound CGP $18137 \mathrm{~A}$ which is to be re-

garded as a hydralazine-like vasodilator. Sequential hydrolysts by acylase and glutamyltranspeptidase is needed in order to generate the active substance. These reactions occur in the kidney at a higher rate than in other tissues (Orlawskl et al, 1980). Renal vasodilator prodrugs may offer an alternative approach to the question of selective renal vasodilatation as a mechanfsm of treating hypertension. In the later chapters of this thesis, this approach will be discussed in more detail.

\subsection{Aim of the present investigations}

In a previous part of this chapter the posstble advantage of preferential renal vasodilation over other antihypertensives in the treatment of hypertension was discussed. Most antihypertenstve drugs induce intrinsic side-effects, which limits the antihypertensive potential of these drugs and forces the use of comblnation therapy. Sio 
far, the above presented hypothesis for anthypertensiwe action of selective renal vasodilators has not been investigated experimentally. Therefore, the studies described in this thesis were designed to lnwestigate the regional hemodynamic effects of anthypertensive drugs with a spectal emphasis on their renal effects. The ultimate goal of thl thes was to investigate whether selective renal wasodilation could cause long-term anthypertenslve effects. This hypothesis was Lnvestigated with a renal vasodilator prodrug. The effects of this compound were compared with the central and regional hemodynamic effects of other antihypertenstves, i.e. directly acting vasodilators, calcium entry blockers and beta-adrenoceptor blockers. A first requirement for this analysis is the use of a conscious hypertensive animal model. The spontaneously hypertenstve rat was chosen for this purpose. Chapter 2 describes the experimental techniques used for hemodynamic and renal function studes in consclous rats.

In order to fully understand the mechantsms of action of any anthypertensive drug a second requirement is a careful analysis of Lts Interaction with the mechanisms involved in blood pressure regulation. The most important blood pressure regulating mechanism in the acute stcuation is the sino-aortic baroreceptor reflex. The role of the baroreceptor reflex was determined in extended studies by comparing central and reglonal hemodynamles of several antihypertensives In intact and baroreceptor denervated animals.

For a better explanation of these effects the Influence of a non-pharmacologlcal baroreceptor reflex activation (unllateral common carotid occlusion) on reglonal hemodynamics was determined and described in chapter 3 .

Subsequently, chapters 4,5 and 6 describe the results of a number of studies on the acute as well as long-term hemodynamic effects of classical vasodilators, calcium entry blockers and beta-adrenoceptor blockers. Furthermore, the influence of the baroreflex on these effects was assessed in each case. In a number of studies additional measurements of renal function and plastna renin concentration were made. Flnally, in chapter 7 a series of studies ls presented on the acute and long-term hemodynamlc and renal effects of a new renal vasodilator prodrug * 


\section{CHAPTER 2}

MATERIALS AND METHODS

\section{$2.1 \quad$ Antmals}

Male normotensive Wistar-Kyoto (WKY) and male spontaneously hypertensive rats (SHR), aged 10-16 weeks and weighing between 250-350 $\mathrm{g}$, were used in the studies described in this thesis*

The WKY rats were obtained from the original WKY straln and the SHR from the original SHR straln bred at the Central Animal Faclitiles of the University of Limburg, Mastricht, The Netherlands.

Before the experiments, anlmals had free access to standard lab food (Hope Farms, type RMH-TM, Woerden, The Netherlands) and tap water. After surgery, the rats were housed separately. The conditions during the experiments are described in the experimental protocols.

\subsection{Catheters and surgery}

In the experiments described in the following chapters four types of catheters were implanted for different purposes.

\subsubsection{Abdominal aorta catheter}

This type of catheter was developed for direct measurements of blood pressure in conscious rats. In the renal hemodynantc studies, this catheter was used for blood sampling*

The catheter was constructed from a 9-cn plece of $\mathbb{P E}-10$ tubing, heat-sealed to a $1.2-\mathrm{cm}$ piece of $P E-50$ tubling. Two small rims were made at the connection to facilitate securing the catheter. On the other 
end of the PE-50 tubing, a l-cm plece of PE-100 tubing was heatsealed. Thereafter, a 3-cm plece of vinyl tubing (Serva TT63) was slid over the $1 \mathrm{~cm}$ PE-100 tubing. Finally, the PE-10 tubing was bent in a Jshape by dipping it into near-bolling water.

The abdominal aorta was cannulated by an approach through the right femoral artery. Under light ether anesthesia, a smail incision was made in the rlght groin and the femoral artery was freed from connective tissue. After clanping it, a small hole was cut in the vessel and the $\mathrm{PE}-10$ catheter was $1 \mathrm{nserted}$. It was advanced for $3-4 \mathrm{~cm}$ into the abdominal aorta. The catheter was secured to the artery and to the leg muscle with silk and gulded subcutaneously to the neck where it was exterforlzed. The catheter was fllled with heparinized saline (50 IU/ml in $0.9 \% \mathrm{NaCl}$ ) and closed with a metal plug. The catheter was implanted at least one day before the experiments.

\subsubsection{Vena cava catheter}

This type of catheter was used for administration of bolus inJections and infusions in the acute studies in consclous, freely moving rats. The venous catheter was constructed of a 9 -cm piece of $\mathrm{PE}-10$ tubing, sealed to a $15-\mathrm{cm}$ plece of $\mathrm{PE}-50$ tubing. Two sma11 rims were made at the connection and $12 \mathrm{~cm}$ further for suturing the catheter to the leg respectively neck muscle.

Under light ether anesthesla, a small inclsion was made in the right groln and the femoral vein was dissected from the surrounding thssue and clamped with two silk sutures. A small hole was cut in the vessel and the venous catheter was advanced for $4 \mathrm{~cm}$ tato the vena cava. After fllling the catheter wh heparinized saline (50 IU/ml in $0.9 \% \mathrm{NaCl}$ ), It was closed with a metal plug. The cannulation was performed at least one day before the start of the experiment.

\subsubsection{Jugular veln catheter}

This type of catheter was used for long-term infusions $\mathbb{i n}$ combination with the Alzet ${ }^{\text {TM }}$ osmotic minlpump (Smits, 1980). The catheter was constructed of a $10-\mathrm{cm}$ piece of silastic TM medical grade tubing (Dow-Cornting 602-155). The proximal end was closed with Silastic TM medical adheslve slilicon type A (Dow-Corning 891) and the same mate- 
rial was used to make two small rims in the middle of the tublug. After a drylng period of $24 \mathrm{hr}$, the catheter was punctured with 0.6 mm needle $8 \mathrm{~mm}$ from the silicon-closed proximal end.

surgery was performed under light ether anesthesia. Through a 2-crl ventral wid-1 ine incision in the neck the right jugular vein was localized and freed from surrounding tissue. A small hole was cut in 14 and the plugged end of the catheter was advanced into the vessel for $3 \mathrm{~cm}$. The catheter was fixed to the vessel and the neck muscle. The distal end was passed through the muscles of the back of the neck and exteriorized there. It was fllled with heparinized salline and closed with a ligature and stored subcutaneously untll the osmotic minipump was connected. The catheter was implanted at least one day before the start of the experiment.

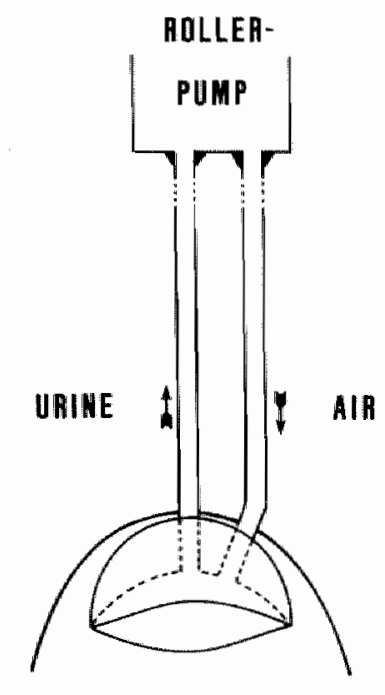

\section{BLADDER}

Pig. 2.1: Schematic dmawing of the bladder catheter.

\section{2 .4 Bladder catheter}

This type of catheter (see $\mathrm{ftg} 2.1$ ) was used for continuous urlne sampling in consclous rats (Daemen et a1, 1987). The Implant- 
ation of the bladder catheter performed 3-4 days before the experiment. In a small ethylene vinyl acetate co-polymer (EVA) cup (diameter $5.5 \mathrm{~mm}$; removable flow moderator cup from Alzet 2001 osmotic minlpup; Alza corporation, Palo Alto, $\mathrm{Ca}$, USA), two holles were made with a hot $0.8 \mathrm{~mm}$ needle. PE-50 tubing $(25 \mathrm{~cm})$ was inserted into each hole. The tubing fitted snugly in the holes and did not need further fixation to the EVA cup. The catheter system was then sterilized with ethylene oxide. For implantation, a small supraputic incision was made. The bladder was exterlorized and flxed by clamping it with a small hemostat, the ends of which were covered with silicon tubing. A 6-mm incision was made in the apex of the bladder, taking care not to cut blood vessels. The vinyl cup was lnserted chrough the Incistion after which the bladder wall was repalred wth 6-0 sllk sutures and an atraumatic needle. This procedure was carried out under strict aseptic conditions. The $\mathrm{PE}-50$ tubing was then tunneled subcutaneously to the neck. where both catheters were extertorized. The bladder catheter system was carefully flushed with sterile $0.9 \% \mathrm{NaCl}$ solution, using one of the tubes as an inlet and the other one as an outlet. The catheters were then closed with metal plugs.

\subsection{Measurements of central hemodynamics}

At least 4 days before the start of central henodynamic experiments, rats were anesthetized whth pentobarbttal (60 mg/ $\mathrm{kg} 1 . \mathrm{p} \cdot)$. The skln was opened over the right thitd intercostal space and the underlylng muscle layers (m. pectoralis profundus and m. rectus abdominus) were cut. After this, the trachea was lntubated and artficlally ventllated wh 60 breaths/min (tidal volume $1.5-3 \mathrm{~m} 1$ ), using a Harvard resplration pump (model 680, Harvard Milles, Mass, USA). Then, the thorax was opened by making a small hole in the intercostal muscle and pleurae using forceps. Thereafter, the intercostal muscle and pleurae were carefully cut over a distance of approxlmately 15 wh whout damagling the lungs. The ribs were spread with a miniature retractor and the aorta was prepared free. An electromagnetic flowprobe with a dfameter of $2.4 \mathrm{~mm}$ (Skalar, Delft, The Netherlands) was placed around 
the ascending aorta at a distance of 3-4 min from the heart. The probe cable was guided subcutaneously to the neck where the connector was secured to the skin. Detalls of the procedure have been described elsewhere (Smith and Hutchins, 1979; Solts et al, 1982). At least one day before the start of the experiments, venous and intra-atterial catheters were implanted under light ether anesthesla. A PE-10 catheter for intravenous injections was implanted into the vena cava through the right femoral veln. Arterial blood pressure was measured via PE-10 catheter in the abdominal aorta, through the right femoral artery. Both catheters were guided to the neck where they were exterlorized. After the catheters had been filled with heparinized salline (50 IU/ml) they were closed with metal plugs.

On the morning of the experimental day, the implanted measuring devices were connected to the respective equfpment. Arterial blood pressure was measured from the intra-aortic catheter, using a miniature strain-gauge transducer (model CP-01; Century Technology Company, Inglewood, Ca, USA). Blood flow through the ascending aorta was measured with a slne-wave electromagnetlc flowmeter (Skalar, model 601, Delft, The Netherlands). Late diastalic flow was taken to be zero and mean blood flow was used as a measure of cardfac output. Heart rate was obtained from elther the pressure or the flow slgnal which were used to trigger a tachograph. Mean signals were obtalned by Low-pass flltering of the signals.

Cardiac output was normalized for body welght (cardlac index, CI) and expressed as $\mathrm{ml} / \mathrm{min} .100 \mathrm{~g}$ body weight. The total peripheral resistance index (TPRI) was calculated from $C I$ and mean arterlal. pressure (MAP) according to: TPRI = MAP/CI and expressed as ma Hg.min. $100 \mathrm{~g}$ body weight $/ \mathrm{ml}$. Stroke volume Index (SVI) was calculated according to: SVI $=\mathrm{CI} / \mathrm{HR}$ (HR=heart rate) and expressed as $u 1 / 100 \mathrm{~g}$ body weight.

\subsection{Measurement of reglonal blood flows}

Reglonal blood flows were measured in separate series of SHR or WKY usfing a 20-MHz directional pulsed Doppler system with mintaturized 
Doppler probes (Haywood et al 1981; Simts and Struyker Boudier, 1984). The abdonen was opened under pentobarbital $(60 \mathrm{mg} / \mathrm{kg} .1 . \mathrm{p} \cdot)$ anesthesia. Doppler probes were placed around the left renal artery (0.8-0.9 min), the superior mesenterlc artery $(0.9 \mathrm{~mm})$ and the abdominal aorta $(1.2$ min) distal to the 11 iolumbar arterles (see fig 2.2). The latter flow conelsts mainly of blood flow through the skeletal muscle of the hindquarters and 11 be referred to as hindquarter flow. The abdomen was closed and the probe cables were guided to the neck where they were soldered to a mintature connector which was mounted on the animal's skull with jewellet's screws and dental cement. After this surgery, the animals were allowed 2-4 days for recovery before implantation of arterlal and venous catheters according to the procedures described above.

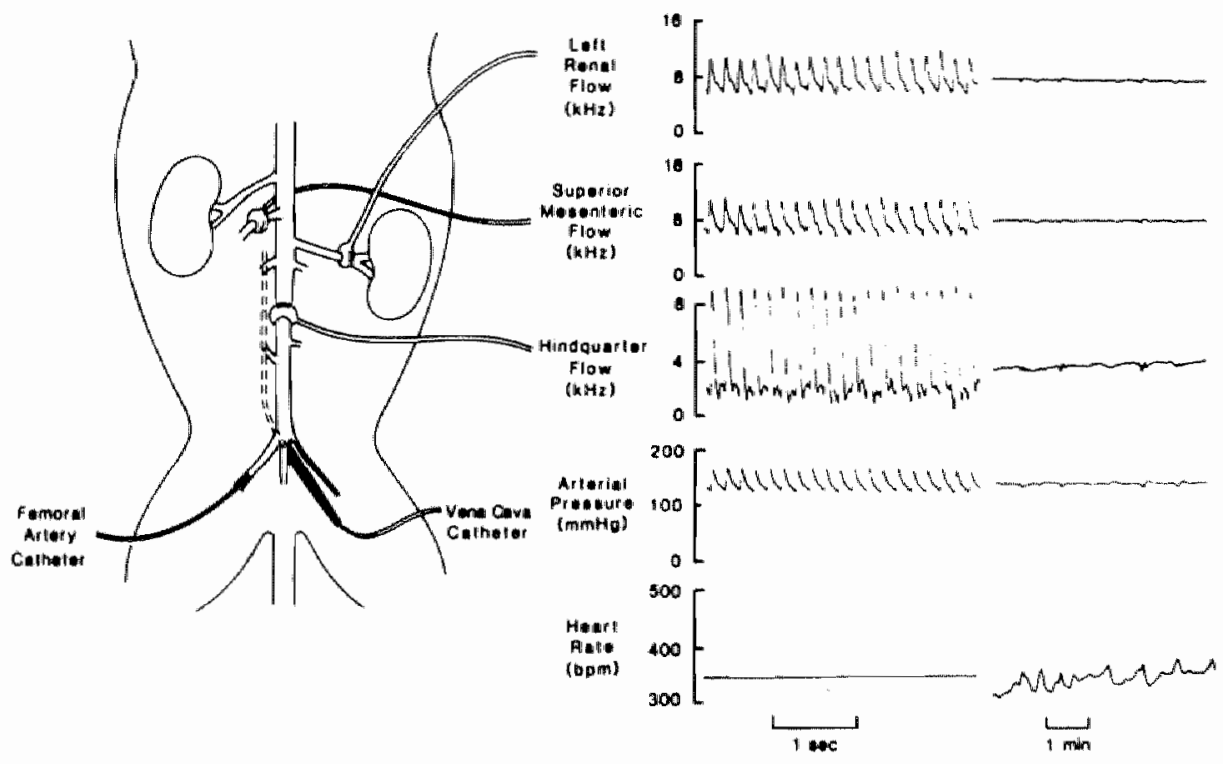

Fig. 2.2: The lay-out of the antmat preparations and pulsatile flow tracings of the renat, abdominat, and mesenteric blood flow measured as frequency shifts using a $20-M H z$ dimectional putsed Doppler flowneter. A catheter in the femoral artery permits simultaneaus monitoming of anterial pressure (Haywood et at, 1981). 
At least one day after catheter implantation, the animals were connected to the measuring equiprent. Reglonall blood flows were measured as $\mathrm{kHz}$ Doppler shift, using in 4-channel $20 \mathrm{MHz}$ drectional pulsed Doppler system (Bioenglneering Department, University of Iowa City, Ia, USA). It has been documented elsewhere that the Doppler shift is directly and linearly proportional to volume flow (Haywood et a1, 1981). Zero blood flow was determined electronically. Mean flows were obtained by low-pass filtering. MAP and HR were measured continuously according to procedures described above. Regional reslstance changes (renal resistance: RR; mesenterlc resistance: MR; hindquarter resistance: HQR) were calculated from the Elow and MAP changes as:

$$
\Delta R=\left[\frac{\Delta M A P+100}{\Delta \text { Flow }+100}-1\right] \times 100
$$

where all changes are expressed as percentages.

\subsection{Baroreceptor denervation}

The role of the baroreceptor reflex in the hemodynanic effects of vasodilators was assessed by baroreceptor denervation according to a method previously described (Krieger, 1964; Struyker Boudier et al, 1979). The location of the barareceptors on the blood vessels together wh the main neck nerves are presented in $\mathrm{fig} 2.3$. After exposure of the sheaths enclosing the common carotid arterles, vagl and sympathetic trunks, both vagi and the carotid arterles were freed from the sympathetic trunks. Aortic afferents were interrupted by resecting a 1-cm strip of the sheath and sympathetic trunk. Afferents from the aorta travelling with the recurrent laryngeal nerves were interrupted by resection of the superior laryngeal nerves. The carotid sinus baroreceptors were denervated by stripplng the carotid bifurcation and its branches and painting the vessels with $10 \%$ phenol in ethanol. This surgery was performed before the implantation of the artic catheter, leaving at least 2 days for recovery.

The effectiveness of baroreceptor denervation was tested accor- 
ding to struyker Boudier et al (1979) by giving the rats an intra-arterlal bolus injection of $5 \mu \mathrm{g} / \mathrm{kg}$ phenylephrine, dissolwed in $0.1 \mathrm{ml}$ $0.9 \% \mathrm{NaCl}$. Thlo increases mean arterial blood pressure by $35-50 \mathrm{~mm} \mathrm{Hg}$. This Increase in pressure normally causes a baroreceptor-mediated decrease in heart rate of 40-100 bpm (Struyker Boudier et al, 1979, 1982). Our criterion for effective surgical denervation was that an increase in MAP of $30 \mathrm{~mm} H \mathrm{Hg}$ or more should not cause a fall in heart rate of more than $20 \mathrm{bpm}$.

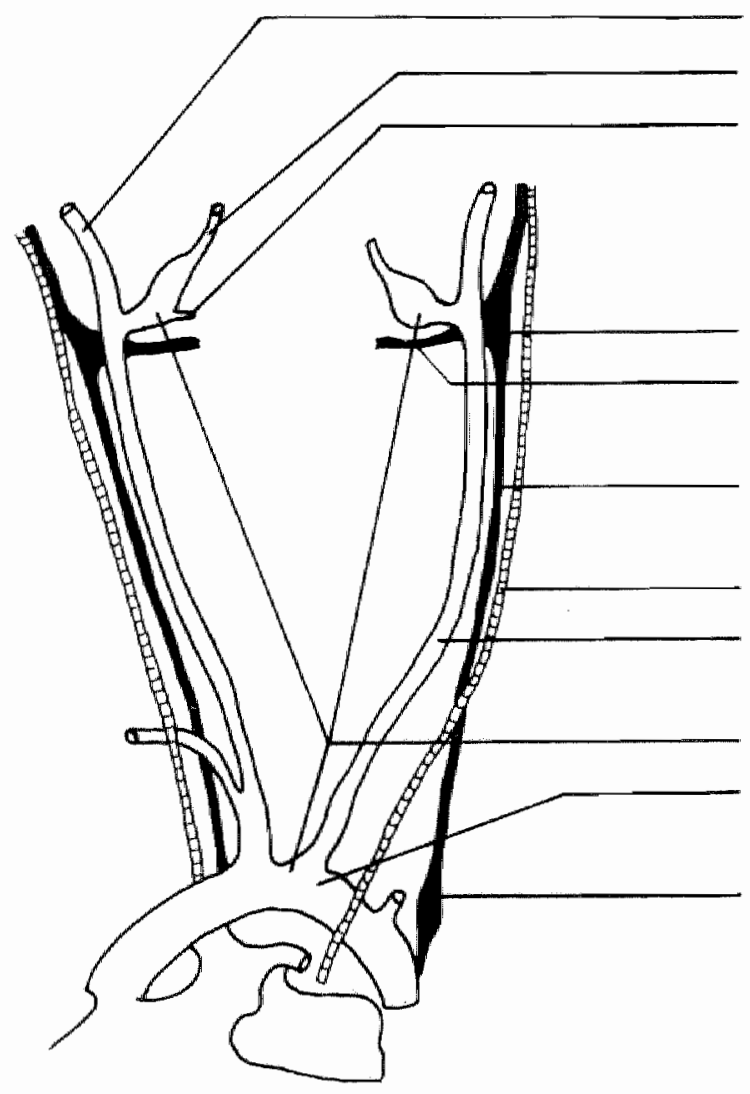

external carowid artery internal carotic arexy superior thycoid artery superior cervical ganglion superior laryngeal nerve superior cervical nerve vagal nexve common carotid artery location of baroreceptors artic arch inferior cerwical ganglion

Frig. 2.3: Gemeral nerve and blood veseel organiadion in the sino aortic area. 
The antmals were anesthetized th $10 \%$ ketamine $10.2 \mathrm{mi} 1 . \mathrm{m}$.: Aescoket ${ }^{R}$ Aesculaap) and $2 \%$ xylazlne (0.1 ml s.c., Rompun, Bayer), (Krieger, 1964; Struyker Boudier et a1, 1979).

A ventral midine incision was made in the neck. The sheaths enclosing the common carotid arteries were exposed and the baroreceptors on the aortic arch and other bifurcation were denervated as described in section 2.5 , to avold a counterregulation by these receptors. Thereafter an occluder and Doppler flowprobe were placed around the right innervated common carotid artery. The occluder was made from a Beckman Dynagraph Inkwel1 tube (Inner diameter 0.85 mm outer dLameter $1.2 \mathrm{~mm})$, at the end of which an inflatable cuff of about $1.5 \mathrm{~cm}$. This cuff was formed by heating $1.5 \mathrm{~cm}$ of the end of the tube at $135^{\circ} \mathrm{C}$ using paraphine ofl and expandling it by air inflation using $1 \mathrm{ml}$ syringe. This cuff was placed around the common carotid artery and fixed on the sternomastoldeus muscle. The rest of the tube was guided subcutaneously to the neck of the rat. Common carotid occlusion (CCO) was established by inflating the cuff and verified from the Doppler flow signal. Baroreceptor unloading was induced by CCO in consclous rats.

\subsection{Plasma renin concentration measurements}

The assay was performed at the department of Intermal Medicine, Dijkzigt Hospltal, Erasmus University, Rotterdam, The Netherlands, in cooperation with the group of F.H.M. Derks and M.A.D.H. Schalekamp.

Plasma renin concentration (PRC) was quantifled by measuring the rate of angiotensin I (AI) formation by renin. Therefore under optimal conditions the unknown renin contalning plasma was uncubated for one hour with endogeneous plasma substrate to generate AI. However, plasma anglotensinases and converting enzyme must also be inhibited in order to protect the newly formed AI from destruction or formation to AII. The AI formed was then quantitated by radiofmmunoassay.

Vila a catheter in the abdominal aorta blood samples (approximately $0.5 \mathrm{~m} 1$ ) were collected into lce-chllled tubes contalning $5 \mu$ 
Na $_{2}$ EDTA ( $100 \mathrm{mg} / \mathrm{ml}$ ) and 0 -phenantralin (1.1 mg/mi). Plasma and cells were separated by centrifugation at $+4^{\circ} \mathrm{C}, 2000$ rpm and plasma was stored at $-80^{\circ} \mathrm{C}$ unt 11 assayed.

Fifty $\mu 1$ of plasina and $150 \mu 1$ renin substrate were mixed with $100 \mu 1$ phosphate buffer ( $\mathrm{pH} 6.6$ ) and $13.5 \mu \mathrm{L}$ anglotensine and converting enzyme inhibltor solution. The renin substrate (plasma with a minimum of plasma renta activity) was prepared from rat plasma which was taken at least $24 \mathrm{hr}$ after bllateral nephrectomy.

Fifty-jul portions of this muture were incubated in triplicate at $37^{\circ} \mathrm{C}$ for I hour. One $50 \mu 1$ blanc sample, wich allowed correction for the endogenoug AI was taken at $t=0$ of the incubation time and immeditely ice-cooled to stop the reaction. The phosphate buffer contalned $12.2 \mathrm{mM} \mathrm{Nall}{ }_{2} \mathrm{PO}_{4}, 86.7 \mathrm{mM} \mathrm{Na}_{2} \mathrm{HPO}_{4}, 75.9 \mathrm{mM} \mathrm{NaCl}$ and $1.0 \mathrm{mM}$ $\mathrm{Na}_{2}$ EDTA. The inhlbition solution was a mixture of a $5 \%(w / v)$ phenylmethyl sulfonyl fluoride (PMSF) solution, a $10^{9}$ IU/ml trasylol, a 100 mol/1 $\mathrm{Na}_{2}$ EDTA solution, and a $10 \%$ (w/v) neomycin sulphate solution In a $1: 2: 2: 2(v: v: v: v)$ ratio. After the incubation $50 \mu 1$ portions were used for the radioimmunassay to determine the formed AI. These 50 ul samples were mixed with 250 jil tris/ acetate buffer, pH 7.5, $50 \mu 1$ antiserum and $50 \mu 11^{125} \mathbb{I}-\mathrm{AI}$ solution $(+7000 \mathrm{cpm})$ and incubated overnight by $0^{\circ} \mathrm{C}$.

The ${ }^{125}$ I-labeled $I 1 e^{5}-A I$ and anti-I1 $e^{5}$ AI rabbit antiserum were prepared as described previously (Derks et al, 1978). The Tris acetate buffer contalned $0.1 \mathrm{M} T \mathrm{Tr}$, $0.35 \%(\mathrm{w} / \mathrm{v}$ ) bovine serum albumin, $0.1 \%$ $(w / v)$ lysozyme, and $0.2 \%(w / v)$ neonycinsulphate. The $\mathrm{pH}$ was adjusted with glactal acetle actd.

The next morning $0.5 \mathrm{ml}$ of a charcoal suspension was added to the lncubate to separate the antibody bound AI. The charcoal suspenston was prepared by mixing $2.5 \mathrm{~g}$ of Dextran $\mathrm{T} 70$ (pharmacla) and $25 \mathrm{~g}$ of charcoal (Sigma Chemicals Mo 63178) with 11 barbital buffer ( 131 mM NaCl, 7.1 mM sodfum barbital and $7.1 \mathrm{mM}$ sodium acetate, pH 7.5). The cubes with this mixture were shaken carefully and then centrifugated (2000 rpm, $10 \mathrm{~min}$ ) at room temperature. The charcoal precipitate and the supernate were counted separately in a gama counter (LKB). Calculations of plasma renin activity were described previousiy (Fybrquist et al, 1976) and PRG is expressed as ng AI generated per m1 
plasma per hour.

2.8

Renal hemodynamic measurements

In this thesis, two dffferent methods were used to determine glomerular filtration rate (GFR) and effective renal plasia flow (ERPF), measured as plasma clearances of ${ }^{51} \mathrm{Cr}$-EDTA and ${ }^{125}$ I-PAH. Both methods have been described prevlously by Smits et al (1983; method $\mathbb{A}$ ) and Daemen et al (1987; method B). The later developed method $B$ has the advantage above method $A$ that it allows a continuous urine sampling during the experiment. During surgery rats were under ether anesthesia.

\subsubsection{Method A}

One day before the experiment andmals were equipped with venous polyethylene (PE-10) catheters in the right femoral veln for bolus injections and an arterial catheter in the right femoral artery for blood sampling. Repeated blood sampling during 90 min after bolus injections of $10 \mu \mathrm{CL}$ of ${ }^{51} \mathrm{Cr}-\mathrm{EDTA}$ (CJ 13p Radiochemical Center, Amersham, England) and $10 \mu \mathrm{Cl}$ of ${ }^{125} \mathrm{I}-\mathrm{PAH}$ (IM $315 \mathrm{P}$ Radiochemical Center) and subsequent fltting of obtalned plasma curves to a two-compartment open mode1 allowed simultaneous calculation of GFR and ERPF. GFR and ERPF are expressed as milliliters per minute per gram of kidney weight. Filtration fraction (FF) was calculated as GFR/ERPF.

\subsubsection{Method B}

Three-5 days before the experiments a spectal ethylene-vynd1 acetate copolymer dome was implanted lato the bladder (the construction is described in section 2.2) allowing continuous urine sampling in consclous animals. One day before the experiment two venous catheters were implanted into the right femoral veln and one arterlal catheter into the right femoral artery. Via one of the venous catheters a bolus injection of $0.5 \mu \mathrm{Cl}{ }^{51} \mathrm{Cr}$-EDTA and $1 \mu \mathrm{Cl}{ }^{125} \mathrm{I}$-h1ppurate (CJ, L3P respectively IM, 315P, Radlo Chemical Center Amersham) was given followed by an infusion of a mixture of both tracer substances 
to dellwer ${ }^{51}$ Cr-EDTA and ${ }^{125}$ I-PAH at rates of $0.6 \mu \mathrm{Cl} / \mathrm{hr}$ and 1.8 uCl/hr respectively. After reaching a steady state for the tracers in plasina and urine, the blood (vla the arterial catheter) and urine (via the bladder catheter) sampling was started. Urine samples were collected continuously in two 15-min periods before the bolus injection and in 30-min perlods during the following $3 \mathrm{hr}$. Mid-times, blood samples were taken, assuming that ${ }^{51} \mathrm{Cr}$ EDTA and ${ }^{125}$ PAH concentrations in these amples are representative for one whole period. GRR and ERPF were calculated from urine and plasma concentrations of both radioactive substances according to standard methods. FF was calculated as GFR/ ERPF.

\subsection{Renal excretory function measurements}

Urine and sodium excretion were quantitated in consclous SHR that were in carefully controlled balance as described in detall prevlously (Smits et al, 1982). Animals were implanted wth catheters In the vena cava and abdominal aorta. After 2 to 3 days of recovery, durfing which antmals had free accesis to standard lab food and water, they were placed in metabolic cages (Techniplast; Bugugglate Varese, Italy). Normal food was replaced by sodium-depleted food (Hope-Farms, Woerden, the Netherlands) and sodium and water 1ntake were controlled by a continuous 1.a. Infusion of a Ringer's solution $(9.0 \mathrm{~g} \mathrm{NaCl,} 0.20$ $\mathrm{g} \mathrm{KCl}$ and $0.20 \mathrm{~g} \mathrm{CaCl}_{2}$ per 1iter, adjusted to ph 7.40 with a phosphate buffer) at a rate of $0.92 \mathrm{ml} / \mathrm{mln}$. The outlet of the metabolic cages was connected to an LKB model 700 fraction collector which was set to change (preweighed) tubes every $120 \mathrm{~min}$ * $V$ was determined every $2 \mathrm{hr}$ by welghing the tubes. $\mathrm{Na}^{+}$-concentrations were measured using a flame photometer.

\subsection{Substances used in this thesis}

The chemical structure of the antihypertenstve drugs used in the studies described $1 \mathrm{n}$ this thesis are presented in $\mathrm{f} 1 \mathrm{~g} \cdot 2.4$. In chapter 

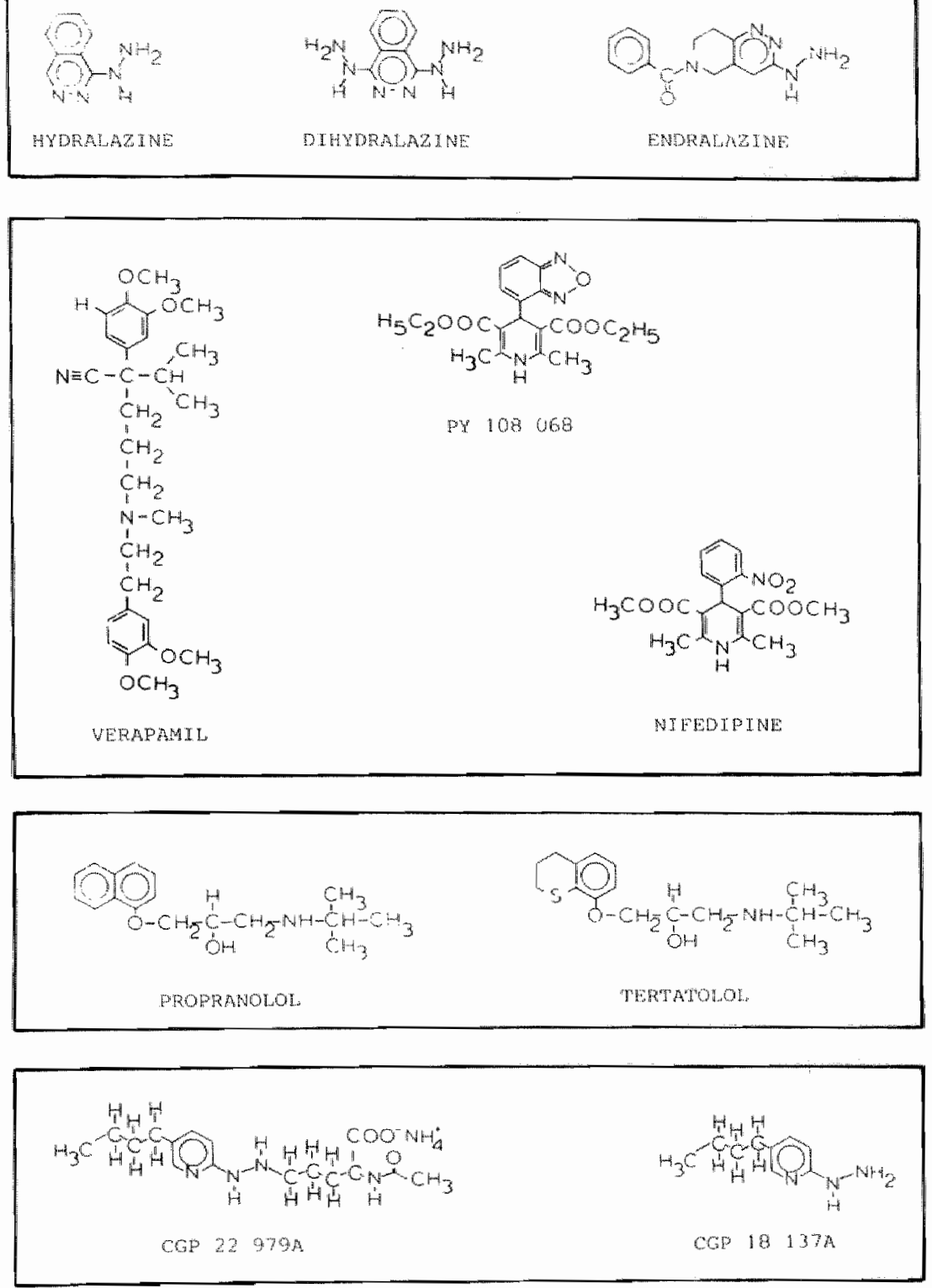

Pig. 2.4: Chemical structure of the diffement substances btudied in chapter $4-7$ of this thesis. 
4, hydralazlne hydrochlorlde (Ciba Geigy) and hydralazine-like substances as dihydralazlne hydrogen sulphate (Clba-Gelgy) and endralazlne (Sandoz) were investlgated. All these drugs were dissolved in $0.9 \%$ MaCl (saline).

In chapter 5, the phenylalkylamine calcium entry blocker verapamil hydrochlorlde (Knol1) and two dihydropyridine derivates aifediplne (Bayer) and PY 108-068 (Sandoz) were used. Verapamil was disso1ved in $0.9 \%$ MaCl and the two dihydropyridines in a mixture of polyethylene glycol, ethanol and $0.9 \% \mathrm{NaCl}(\mathrm{v} / \mathrm{v} / \mathrm{v}, 1 / 1 / 2)$.

In chapter 6 , the non-selective beta-adrenoceptor blocking drugs propranolol (Sigma Chemfcals) and tertatolol (Servier) racemates, both wh no latrinsic symathomimetic activity, were used in the described studies. These substances were dissolved $\mathbb{1 n} 0.9 \% \mathrm{NaCl}$.

In chapter 7, two experimental substances were investigated, the prodrug CGP 22 979A and its parent compound CGP 18 137A (Ciba-Geigy), both dissolved in $0.9 \% \mathrm{NaCl}$. CGP 22 979A has no vasodilator activity of 1 ts own but a hydrolysis by acylase and glutanyl transpeptidase is needed to generate the active hydralazine-like vasodilator CGP 18 $137 \mathrm{~A}$.

\section{11 Statistics}

In the following chapters, three different statistical methods were used to compare hemodynamic values in several experimental groups:

1. Student" s-test for unpalred observations. This method was used to compare maximally two groups of unpalred values in one study*

2. One-way amilysis of watlance and a modifled t-test for mutple comparison, following the Bonferronl method (Wallensteln, 1980). This method was used to compare more than two groups of unpalred values in one study with a one-way analysis of varlance followed by a unpalred comparison wh the modifled t-test.

3. Analysis of varlance for repeated measurenents (Zerbe, 1979). This method was used to compare the values of two groups with repeated measurements. 
A differentiation of these methods over the several types of experiments are presented below.

\section{11.1 Baseline values}

Absolute values measured before a bolus injection or start of infusion were compared wh method 1 . Only if more than two groups were used in one study, baseline values were compared using method 2 .

\subsubsection{Central hemodynamic studies}

In these experiments, a comparison was made between the effects in the control group and one group recelving a particular dose of a drug. The values were measured when maximal effects were reached or at one time period. Also differences between central hemodymamics at one dose in intact and sino-aortic baroreceptor denervated animals were compared with method 1 .

\subsubsection{Acute reglonal hemodynamic studies}

Similarly as in the central hemodynamic studies, the values of the control group were compared with the values in the drug treated group at one particular dose using method 1.

The regional hemodynamic dose response curves in intact and sino-aortic baroreceptor denervated animals were compared with method 3 because more than one dose was used in one group to deternine these effects.

\subsubsection{Renal hemodyanle and excretory functlon studes}

In these studes, method 2 was wat to compare the effect in

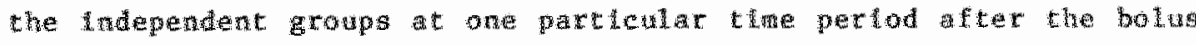
injecton. The andmals recelved per group only one dose of one arug.

\subsubsection{Long-tera reglonal hewodyantc atudes}

In these studies reglonal hemodynamic effect were measured every day over a perlod of several way. Wethod 3 for rewedu neasurements was to compre these long-term effects between two differenty treated groups. The anmals recelved one lifuslow per group . 
2. 11.6 plabma renin concentration studies

In these studfes, plaswa renin concentration was deterwined just before and after a 4-day infuston period of several substances. The measured absolute values were statistlcally compared with the control values at particular times (day 0 or day 4). When two independent groups were used In the study method 1 was used, but in the case of more than two groups, method 2 was used for comparison. 
CHAPTER 3

EFFECT OF BAROREFLEX ACTIVATION ON REGIONAL HENODWNAMICS

IN CONSCIOUS NORMOTENS IVE RATS

\subsection{Introduction}

As described in chapter 1, the baroreflex is an important mechanism in the short-term control of the cardiovascular system. In the following chapters, the hemodynamic effects of some classes of anthypertensive drugs are described. "These substances reduce blood pressure and consequently, activate sino-aortic barorecepor reflex mechanism. This leads to further changes in vascular flow and resilstance counterregulating the fall in blood pressure. In those studles, the role of the baroreceptor reflex in the acute regional heinodynamic effects of the drugs were investigated in lntact and sino-aortic baroceceptor denervated animals. Those studles do not answer the question whether the reglonal specificity in the intact animals is the result of an additive direct effect of the drug and the reflex on the vascular beds or an interference of the drug with the sino-aortic baroreflex pathway. This question may be answered if the reglonal hemodynamic effects of baroreceptor reflex activation are known. Therefore, the study described in this chapter was designed to determine regional hemodynamic effects, induced by a non-pharmacologlcal baroreflex activation.

Sone investlgators hawe used non-pharmacologlcal methods to activate the baroreflex mechanism to investlgate reglonal hemodynamics. Bond and Green (1969) induced a carotid sinus pressure reduction by bilateral carotid accluston in anesthetized dogs and observed a baroreflex-mediated increase $\mathbb{t n}$ vascular resistance th the viscera, kidney and skeletal muscle. Cox and Bagshaw (1980) activated the baroreflex by controlled external saline perfusion of the carotid sinus area and found a similar inverse relationship between carotid 
silnus pressure and resistance in mesenteric, renal and femoral vascular beds. In these experiments, it cannot be excluded that the anesthes (Cox and Bagshaw, 1979) or the strongly reduced cerebral blood flow Lnfluences the baroreflex-induced hemodynamic effects. Therefore, in this study we have activated the baroreflex in consclous wKY rats by unllateral common carotid occlusion (CCO) and lnvestigated its effect on regional vascular resistance. The baroreceptors on the aortlc arch and other bifurcation were denervated to avold a counterregulation by these baroreceptors. In separate studies we determined the relationshlp between carotid sinus pressure and systemic MAP during CCO in anesthetized rats and the direct effect of CCO on MAP and HR in consclous totally denervated rats. In addition, we have checked the influence of such partial denervation on baroreflex senBitivity.

\subsection{Experimental protocols}

\section{$3.2,1$ Antioalls}

Male normotensive Histar-Kyoto (WKY) rats of age ranging from 3-4 months were used in all. the studies described in this chapter (for more detalls, see paragraph 2.1).

\subsubsection{Protacol for denervation and baroreflex sensitivity measurements}

4 Days before the experiments 5 groups or wkr rats were sub Jected to elther total, unflateral or sham denervation. The baroreceptor denervation 1 s described in section 2.5. In the untlaterally denervated group the Innervation of the baroreceptors on the right carotid slnus was left intact. Three days later, under ether anesthesla, a catheter was placed into the abdominal aorta for MAP and heart pertod (HP=60.000/HR) measurements. Bolus injectlons of phenylephrine were adminlstered via a catheter in the vena cava. On the expertmental day, baroreflex sensttivity (BRS) was determined in the 3 different groups by linear regression analysis of HP and MAP induced by different doses of phenylephrine. The slope was used as an index for BRS, if $p<0.05$. 
3.2.3 Protocol for determining the relationshlp between carotid sinus pressure (CSP) and systemic MAP

Surgery and measurements were performed in pentobarbltal anesthetized animals. On the experimental day an occluder was placed around the left common carotid artery and the superior thyrold artery was cannulated in a retrograde fashion with the tip in the carotid sinus. The femoral artery was cannulated for MAP measurements and the femoral vein for infusions. MAP was varied by infusions of anglotenstin II and nitroprusside sodium. At several levels of MAP, a cco was performed. The relationship between MAP and CSP was determined by inear regression analysis.

3.2.4 Protocol for carotid occlusion and measurement of regional hemodynamies

Reglonal blood flows were measured uslug a $20 \mathrm{MHz}$ dtrectional pulsed Doppler system with miniaturlzed Doppler flow probes according to Haywood et al (1981).

Six days before the experiments the rats were unilaterally denervated as described in chapter 2. In addition, an occluder and Doppler flow probe were placed around the right (tanervated) common carotid artery. Three days later, Doppler flow probes were Implanted around the renal, superior mesenterlc artery and abdominal aorta. After 2 days of recovery the abdominal aorta was cannulated for MAP and HR measurements. On the experimental day the animals were connected to the registration equipment. They were allowed to habltuate to the experimental conditlons for at least 1 hr. Thereafter, the changes in MAP, $H R$, renal (RF), mesenteric (MF) and hindquarter (HQF) flow to steady-state levels, induced by a $20-8$ unflateral CCo perfod were determined and resistance changes were calculated. In a separate group of totally denervated animals, the effect of CCO On MAP and HR was measured.

\section{3 Results}

\subsubsection{Effect of denervation on BRS}

Pre-injection values of MAP and HR in the sham-operated, in the 
Pable 3.1: Pre-injegtion value of MAP(mm Hg) and HR(bpm) in the hom-operated wantatemalzy denemated and totally dener vated group (mean + SEM). Significant difference are gitien in compariaon to shan denemation: *0<0.001.

MAP

HR

\begin{tabular}{llll} 
Sham & 8 & $128+3$ & $341 \pm 7$ \\
Untlaterally & 8 & $141 \pm 6$ & $387 \pm 10 *$ \\
Totally & 7 & $136 \pm 6$ & $393 \pm 11 *$ \\
\hline
\end{tabular}

unilaterally denervated, and In the totally denervated group, are summarized in table 3.1. In unilaterally and totally denervated animals, HR pre-injection values were signiflcantly higher $(p<0.001)$ than in sham-operated rats.

Flg. 3.1 shows typlcal regression lines for HP vs. MAP following intravenous phenylephrine in sham, unilaterally and totally denervated rats. The slope was used as an index for baroreflex sensitivity. BRS was $1.5+0.8 \mathrm{~ms} / \mathrm{mm} \mathrm{Hg}(\mathrm{n}=8)$ in lntact animals. After unilateral denervation, BRS was signlficantly 1 wer $10.6+0.3 \mathrm{~ms} / \mathrm{mm} \mathrm{Hg}$; $\mathbf{n}=8 ; \mathrm{p}<0.01)$. Total baroreceptor denervation virtually abolished BRS $(0.14+0.9 \mathrm{~ms} /$ mon $\mathrm{Hg} ; \mathrm{n}=7 ; \mathrm{p}<0.02)$.

\subsubsection{Relat lonship between systemic MAP and CSP during CCO}

Before occluston, CSP equalled MAP. The relationship between MAP and CSP during CCO may be described as CSP $=0.61 \times \mathrm{MAP}+3.1 \mathrm{~km} \mathrm{Hg}$ wh a coeffictent of correlation of 0.93 ( $\mathrm{f} 1 \mathrm{~g} \cdot 3.2$ ).

\subsubsection{Effect of unilateral CCO on regtonal hemodynamics}

Pre-occlusion walues of MAP and $\mathrm{HR}$ were $134+17 \mathrm{~mm} \mathrm{Hg}$ and $406 \pm 18$ bpm in the totally denervated, and $109+7 \mathrm{~mm}$ Hg and $357+14 \mathrm{bpm}$ in the unilsterally denervated group.

The hemodynamtc changes laduced by unilateral cco are sumarized in firg. 3.3 . 
In totally denervated rats, cco did hardly affect MAP $(2+1)$ and $(2 \pm 1 \%)$. In unilaterally denervated animals, MAP increased $(28+4 \%)$. This was associated with vasoconstriction in all 3 vascular beds (RR: $33+8 \%$; HQR: $27+7 \%$, and MR: $24+5 \%$ ), but not by flow changes (RF: $-3+1 \%$; $\mathrm{HQF}:-0.6+3 \%$, and MF: 4\#3\%). This vasoconstriction was more pronounced in the kidney than in hindquarters and mesentery.

\subsection{Discussion}

In this study, we have investigated a non-phamacological baroreflex activation by unllateral cco in consclous rats. The results

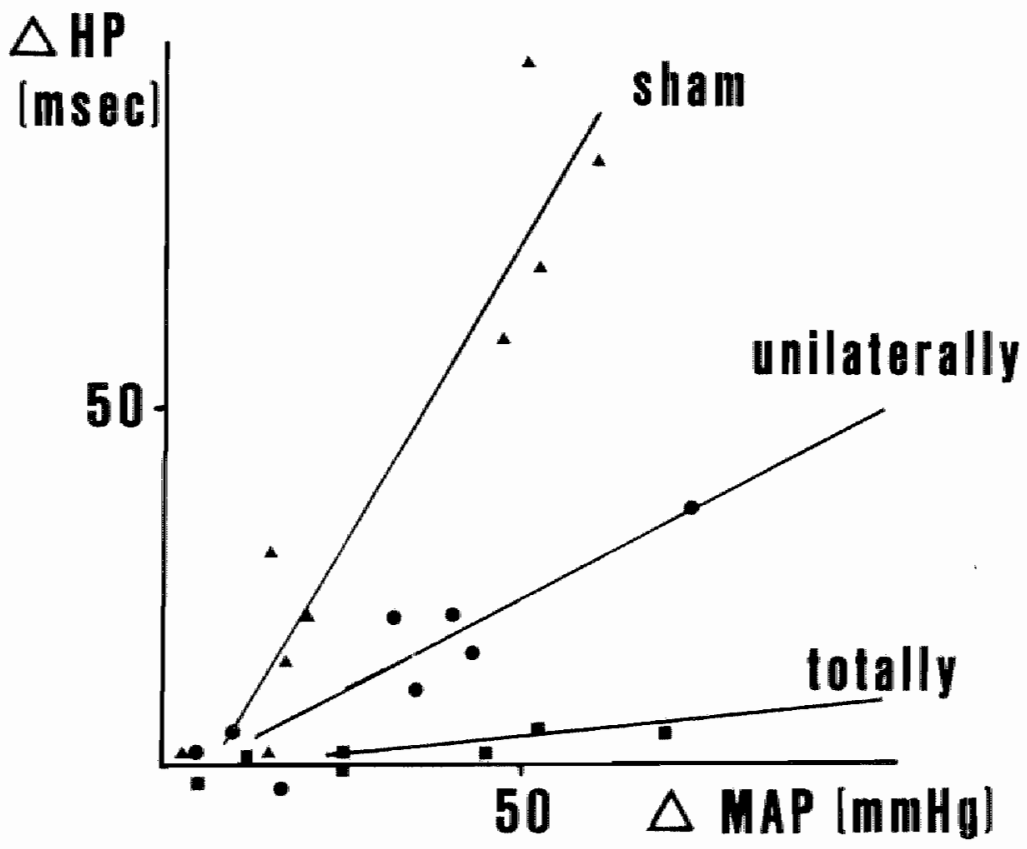

Fig. 3.I: Typical regreagion lines for mean arterial preseure (MAP) v6. heart period (HP) following intravenous phenylephmine in sham, unilaterally and totaliy denemated rats $(y=1.6 x-13$; $r=0.89 ; \quad y=0.5 x-3.2 ; \quad r=0.91 ; \quad y=0.1 x-1.4 ; \quad r=0.89$ respective ly). 


\section{Carotid Sinus MAP ( $\mathrm{mmHg}$ )}

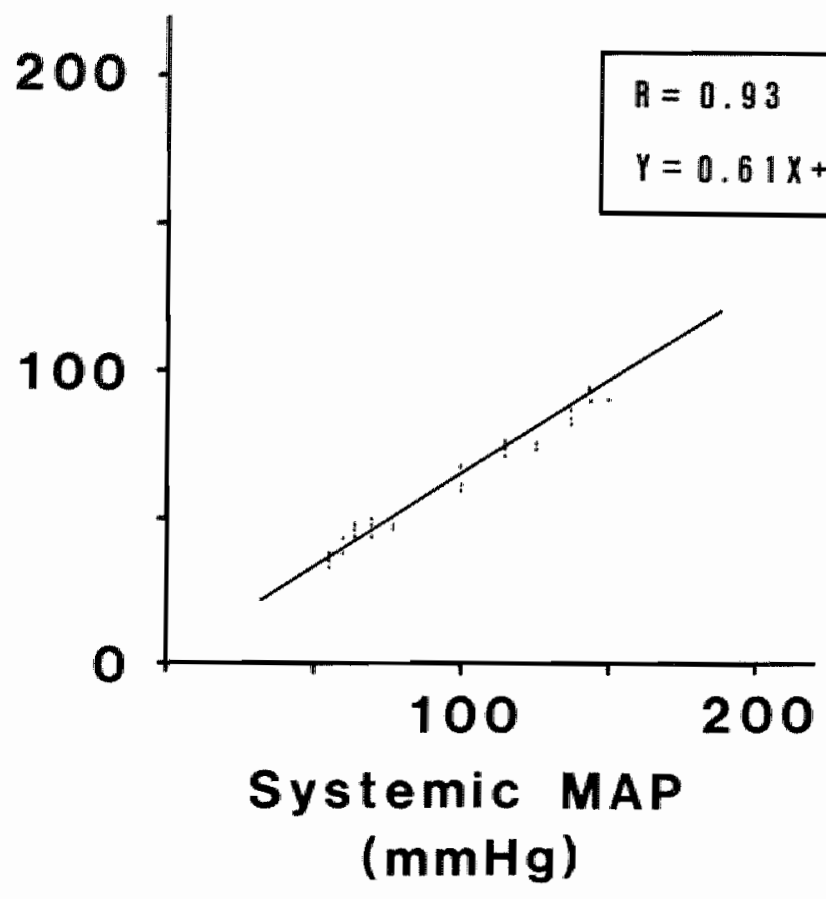

Fig. 3.2: Corretation between the carotid sinue presoure and systemic MAP during carotid occlusion.

show that unllateral cCo reduces CSP by approximately $40 \%$ (fig. 3.2 ). Vla the baroreceptors located in this carotid sinus area the pressure reduction actlvates the baroreflex mechanlsin, inducling hemodynamic changes. The baroreceptors on the artic arch and other bifurcation were denervated to avold counter-regulation by these baroceceptors. It was therefore necessary to test first in a separate study how unilateral baroceptor denervation affects the baroreflex. The results indicate that unllateral denervation reduces $B R S$ but does not abolish the barareceptor reflex (fig. 3.1). Furthermore, unilateral cco did not affect systenlc MAP in totally denervated anlmals. We therefore conclude that $\mathrm{CcO}$ can be used as a non-pharmacologlcal method to 
DRENAL [III]HIND- NMESENTERIC

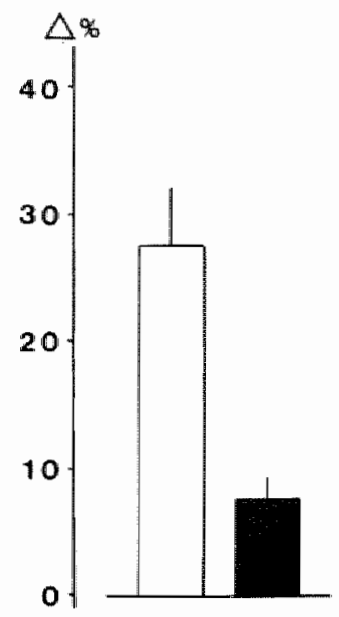

MAP HR

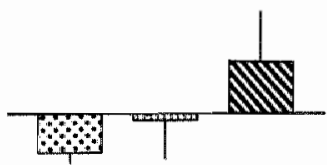

BLOODFLOW
QUARTER

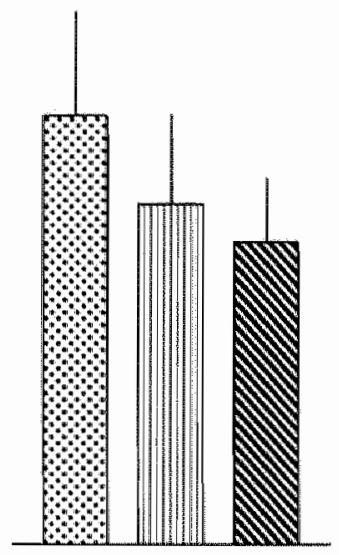

RESISTANCE

Fig. 3.3: Effects of baroreflex actuation induced by unitateral carotid occlusion on mean arterial preasure (MAP), heart. rate (HR) and flow and resistance in the renal, hindquater and mesenteric vascular bed.

activate baroreflex mechanism in conscious small antmals.

The second purpose of this study was to 1 nvestigate the regional vascular effects of baroreflex activation Induced by cco. The Implanted minlaturized Doppler flow probes allowed stmultaneous measurement of flow changes in different wascular beds (Haywood et al, 1981). The results indleate that the baroreflex mechanlsm activated by unllateral stnus pressure reduction, increases MAP by a vasoconatriction in the renal, hindquarter and mesenteric vascular bed, which is most pronounced in the kidney ( $f 1 g$. 3.3). Bond and Green (1969) have shown that activation of the baroreflex mechanlsm by bllateral carotid occlusion increases vascular resistance in kidney, skeletal musicle and viscera in anesthetized dogs to a simflar degree. Cox and Bagshaw (1980), usling a controlled external saline perfusion of the carotid sinus area to activate the baroreflex mechanism in anesthetized dogi, found general vasoconstriction which was most pronounced in the femo- 
ral and least pronounced in the mesentertic vascular bed. These results Indlcate that carotid slaus hypotension induces a baroteflex medlated general vasaconstriction wh some contrary reglonal spectfictity in the different studies. It is not clear whether these alferences derive from specles difference or alternatively from the lack of anesthetic use in the present study.

CCO dId hardly change HR and flow through the three vascular beds. A much smaller effect on cardiac output than on total peripheral resistance was also observed by Kifchhelm and Gross (1971) during bilateral CCO in consclous dogs. A posslble explanation for these observations could be that baroreceptors on the aortle arch are responstble for the baroreflex medlated effects on HR and cardlac output because baroreceptor unloading with depressor substances like nitroprusside sodium which also unloads baroreceptors on the aortic arch causes strong HR Increases (Harron et a1, 1984).

Green and Rapela (1965) suggested that autoregulation of the wascular beds increases vascular resistance during CCO. This hypothesls could explatn the lack in flow changes during CCO in the present study. This was supported for the kidney by Higgins et al (1973), Kurchheim (1969) and Kirchheim and Gross (1970) using alpha-adrenoceptorblocking agents to block the sympathetlc vascular responses. In similar studies, Bond and Green (1969) showed that the Increase in mesenteric resistance could at least in part be due to autoregulation. The resistance increase in skeletal muscle during cco was totally abollshed after alpha-blockade or after removal of the abdominal. sympathetlc chaln (Folkow and Ne11, 1971), suggesting an Increased sympathetic tone in the muscular vascular bed during cco.

In sumiary, the results show that baroreceptor activation leads to a veroconstriction in all vascular beds studied. Passibly, the Increase in vascular resistance is mediated by different mechanisms, e.g. autoregulation and increased sympathetic activity. This was not further investigated in the present study. 
CHAPTER 4

HEMODYNAMIC EFFECTS OF HYDRALAZTNE

AND SOME HYDRALATINE-LIKE ARTERTOLAR VASODILATORS

IN THE CONSCIOUS SPONTANEOUSLY HYPERTEMSIUE RAT

\subsection{Introduction}

Hydralazine and hydralazine-like vasodilators are given as a third step after beta-adrenoceptor blockers and/or diuretics in the treatment of hypertension. This is the result of several less favorable effects occurring during monotherapy with these drugs (KochWeser, 1974; Vidrio and Tena, 1980). The acute hemodynamic effects of arteriolar vasodilators have been descrlbed extensively. In hypertensive man, such studies are difficult to interpret because of the usually combined use of these vasodilators and beta-adrenoceptor blocking drugs (Zacest et al, 1972; Koch-Weser, 1974; Brunner et a1, 1978). In animal studies, an interference of beta-adrenoceptor antagonists with the hemodynamic effects of vasodilators is suggested by Gutkin et al (1977) and Bolt and Saxena (1984a). Therefore, the first study in this chapter was designed to determine the central hemodynamic effects of the vasodilators hydralazine, dihydralazine and endralazine in consclous SHR. We used a technique for measuring continuously cardiac output from an implanted electromagnet fc flow probe on the ascending aorta as described originally by Smith and Hutchins (1979) and developed further by Sints et al (1982).

The primary pharmacological effect of these agents ls a rellaxition of vascular smooth muscles which leads to a (rapid and relatively strong) fall in total pertpheral reslstance and bload pressure. Relatively little is known about which vascular beds are responsible for the strong fall in total peripheral resistance. The few avallable regional hemodynamic studies in man (Z1ns, 1974; Leler et al, 1981) and dogs (Chelly et al, 1986) indicate that hydralazine is a renal vasadflator. However, Bolt and Saxena (1984a) observed not only a 
renal vasodilation, but also a vasodilation in heart and brain and even an increase $1 n$ vascular resistance in skin and gastrointestinal tract after hydralazine.

In a aecond study we have investigated the regional hemodynamic effects of hydralaztme in consclous SHR, using a 20-MHz directional pulsed Doppler system according to Haywood et al (1981).

The strong blood pressure reduction after directly acting arterlolar vasodflators causes a reflex increase in sympathetic nerve activity to the heart and the blood vessels changing the direct hemodynamic effects of these drugs. In a final study, we assessed the role of the baroreceptor medlated reflex mechanisms in the hemodynamic effects of hydralazine. Therefore, acute central and reglonal hemodynanic effects of this drug were determined in sino-aortic baroreceptor denervated and non-denervated SHR.

\subsection{Experimental protocol}

Surgery, measurements and calculations concerning the central and regional hemodynamics were performed as described in section 2.2 and 2.4. of this thesis. The baroreceptor denervation is described in section 2.5. On the experimental day, the animals were placed in experimental cages between 9.00 and $10.00 \mathrm{a} . \mathrm{m}$. After the catheters and flowprobe cables had been connected to the registration equipment, the antmals were allowed to habltuate to the expertimental conditions for 1 hr. Control values ( $t=0$ in the results) were obtalned as the average of 4 readings at 5 -min intervals in the last 20 min before an injectton.

To determine the central hemodynamic effects, 5 different experimental groups recelved intravenously (i.v.) $0.1 \mathrm{~m} 0.9 \% \mathrm{NaC1}$ solution (sallne), $0.3 \mathrm{mg} / \mathrm{kg}$ hydralazlne hydrochlorlde (Ciba-Gelgy), 0.3 $\mathrm{mg} / \mathrm{kg}$ dihydralazlne hydrogen sulphate (Clba-Gellgy), and 0.1 and 0.3 $\mathrm{mg} / \mathrm{kg}$ endralazine mestlate (Sandoz), respectively. In another group of sino-aortic baroreceptor denervated SHR the central hemodynamic effects of $0.3 \mathrm{mg} / \mathrm{kg}$ hydralazlne were measured.

The regional hemodynanic effects of $0.1-1.0 \mathrm{mg} / \mathrm{kg}$ hydralazine 


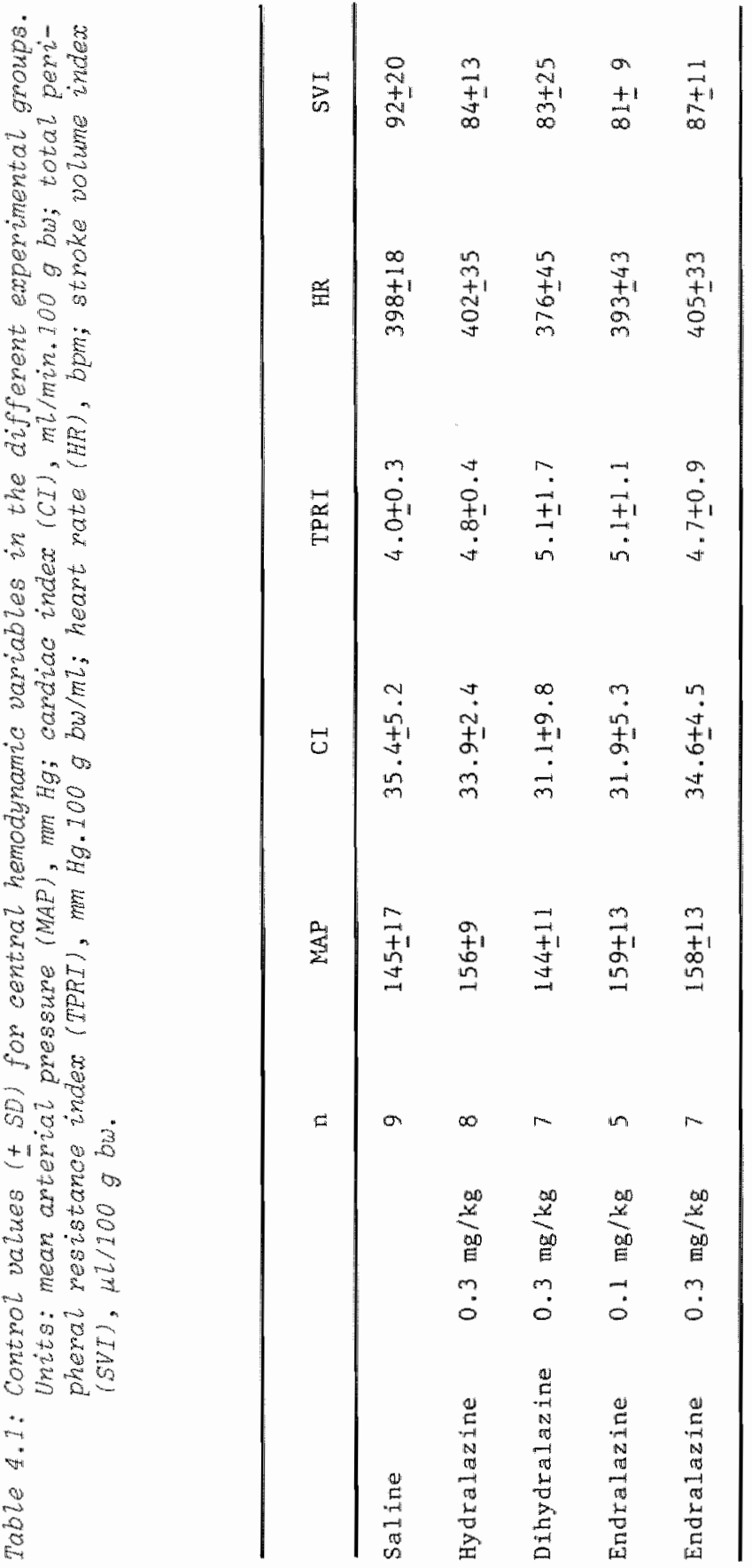




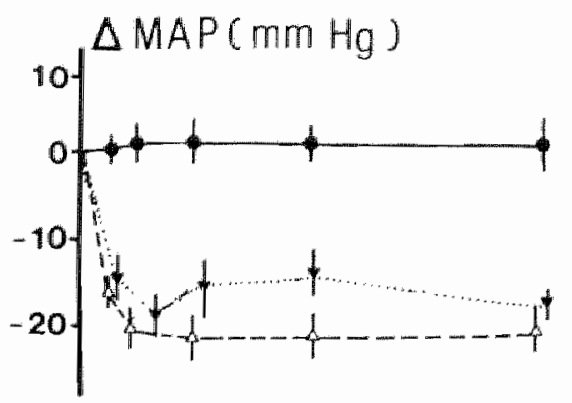

- Saline

$\therefore$ hydralazine

-....... dihydralazine
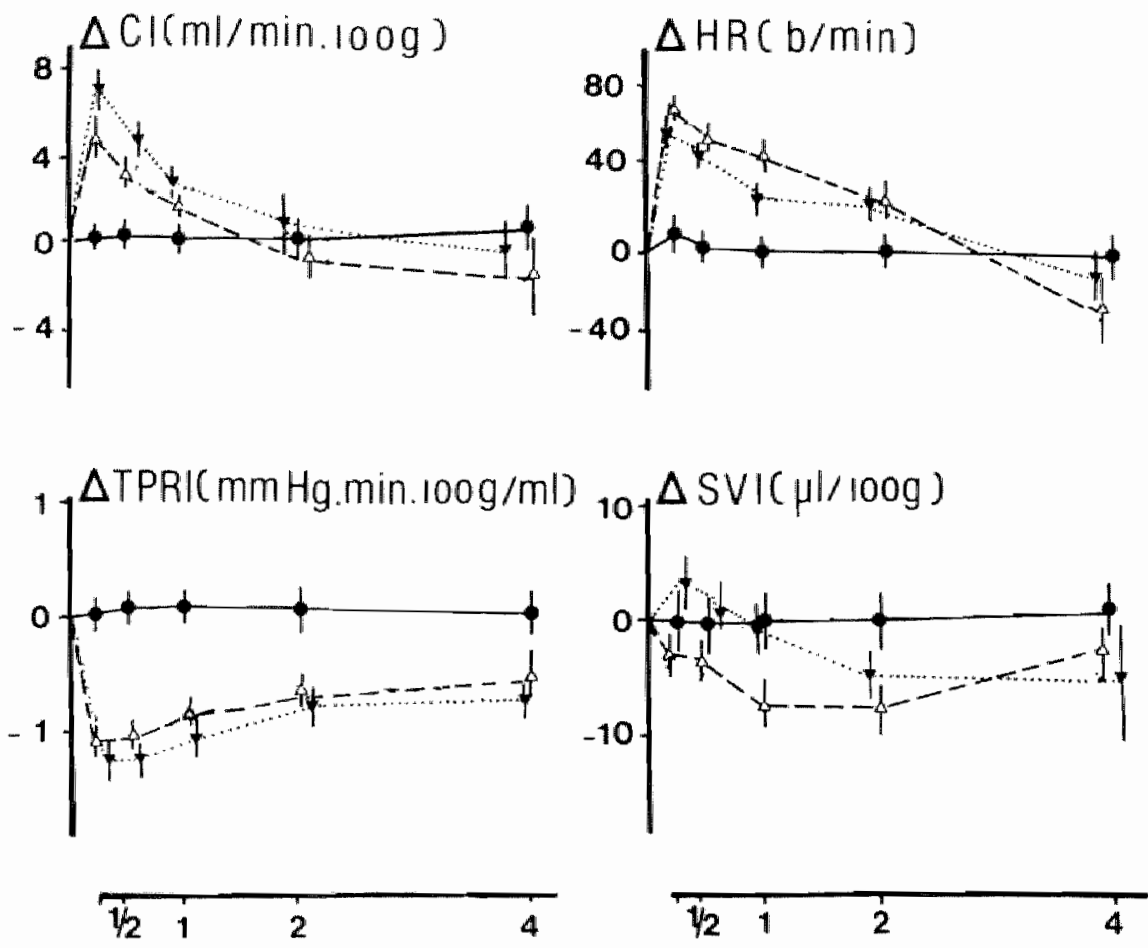

time (hours)

Fig. 4.1: Effecte of $0.1 \mathrm{mi}$ axline, $0.3 \mathrm{mg} / \mathrm{kg}$ hydralazine and 0.3 mg/kg dinydralazine on mean arterial presaure (MAP), caritac index (CI), total pemipheral mesistanoe index (TPRI), heart mate (GR), and stroke volume index (SVI) in conscious SHR. 



Fig. 4.2: Effects of $0.1 \mathrm{~mL}$ saline, $0.1 \mathrm{mg} / \mathrm{kg}$ endratarine and 0.3 $\mathrm{mg} / \mathrm{kg}$ endratazine on mean arteriat preabure (MAP), candiac index (CI), total peripheral mesistance index (TPRI), heart rate (HR), and stroke volume index (SVI) in conscious SHR. 
were determlned in baroreceptor-denervated and non-denervated SHR.

\subsection{Results}

\subsubsection{Central hemodynamic effects of hydralazine and dihydralazine}

Control values for the different groups of rats are summarized in table 4.1 . There were no statistically significant differences between the control values of the hemodynamic vartables for the different groups.

In pllot experiments with separate animals, doses of the 2 wasodilators were chosen that would cause a comparable fall in MAP. The hemodynamic studies were thus performed with $0.3 \mathrm{mg} / \mathrm{kg}$ hydralazine $(n=8)$ and $0.3 \mathrm{mg} / \mathrm{kg}$ dihydralazine $(n=7)$, whereas the control group $(n=9)$ recelved $0.1 \mathrm{ml} 0.9 \% \mathrm{NaCl}$. Both vasodilators caused a rapid fall in MAP (flg. 4.1). A maximum decrease was reached after 1 hr, amounting to $-21+3 \mathrm{~mm} \mathrm{Hg}(\mathrm{p}<0.001)$ for hydralazine and $-18+3 \mathrm{~mm} \mathrm{Hg}$ ( $\mathrm{p}$ $(0.001)$ for dihydralazine. MAP then slowly returned towards its control values. After $24 \mathrm{hr}$, MAP in the hydralazine group did not differ significantly from that in the saline treated rats. Dihydralazine at that time still caused a slgnificant $(p<0.001)$ fall of $-12 \pm 2 \mathrm{~mm}$ compared to $+2+4 \mathrm{~mm} \mathrm{Hg}$ in the saline group. The fall in MAP was parallelled by a decrease in TPRI (fig. 4.1). A maximal decrease of $-1.1+0.1$ ( $p<0.001)$ and $-1.3+0.3(\mathrm{p}<0.001) \mathrm{mm} \mathrm{Hg} \cdot \mathrm{min} .100 \mathrm{~g} \mathrm{bw} / \mathrm{ml}$ was observed for hydralazlne and dihydralazine respectively within 30 min after infection. In the hydralazine treated group, TPRI returned to control levelg at $24 \mathrm{hr}$ whereas a significant $(p<0.05)$ decrease of $-0.8+0.3$ (vs. $+0.1+0.3 \mathrm{ln}$ the sallne group) $\mathrm{mm} \mathrm{Hg} \cdot \mathrm{min} .100 \mathrm{~g} \mathrm{bw} / \mathrm{ml}$ was still observed for the dihydralazine group.

Both vasodilators caused a rapld increase in CI and HR ( $f 1 g$. 4.1). The maximum for this increase was abserved within $30 \mathrm{~min}$. For $\mathrm{CI}$, the rise amounted to $4.7 \pm 0.7 \quad(\mathrm{p}<0.001)$ and $6.5+1.3 \quad(\mathrm{p}<0.001)$ $\mathrm{ml} / \mathrm{min} .100 \mathrm{~g}$ body welght for hydralazine and dihydralazine, respectively. The maximal Increases in HR were $66+8$ bpm $(\mathrm{p}<0.001)$ and $60 \pm 9$ bpm $(p<0.001)$ for hydralazime and dihydralazine respectively. In contrast to the long-lasting decreases of MAP and TPRI, CI and HR re- 
turned to their control values within i-2 hr. After this perlod, no significant differences were observed between the experimental and control groups with respect to $C I$ and HR. No significant changes observed in SVI, although there was a tendency to a decrease after hydralazine.

\subsubsection{Central hemodynamic effects of endralazine}

The hemodynamic effects of a range of doses $(0.1-1 \mathrm{mg} / \mathrm{kg})$ of endralazine were studied. Fig. 4.2 summarizes the effects of $0.1 \mathrm{mg} / \mathrm{kg}$ $(\mathrm{n}=5)$ and $0.3 \mathrm{mg} / \mathrm{kg}(\mathrm{n}=7)$ endralazine. One $\mathrm{mg} / \mathrm{kg}(\mathrm{n}=4)$ caused such at profound fall in MAP $(-87+6 \mathrm{~mm}$ Hg at $t=30 \mathrm{~min})$ that further hemodynamic data are not included. The 2 lower doses cansed a rapid fall in MAP, amounting to $-11+4(p<0.05 ; 0.1 \mathrm{mg} / \mathrm{kg})$ and $-29 \pm 5 \mathrm{~mm} \mathrm{Hg}(p<0.001$; $0.3 \mathrm{mg} / \mathrm{kg}$ ) within $30 \mathrm{~min}$. Thereafter, MAP gradually increased again although it was still reduced by $22 \pm 3 \mathrm{~mm} H \mathrm{Hg}(p<0.001)$ at 24 hr after $0.3 \mathrm{mg} / \mathrm{kg}$. The fall in TPRI was parallel to the fall in MAP, with maximum decreases of $0.8+0.2(p<0.001 ; 0.1 \mathrm{mg} / \mathrm{kg})$ and $1.2+0.1$ ( $\mathrm{p}$ $\langle 0.001 ; 0.3 \mathrm{mg} / \mathrm{kg}\rangle \mathrm{mm} \mathrm{Hg} \cdot \mathrm{min} .100 \mathrm{~g} \mathrm{bw} / \mathrm{ml}$. After $24 \mathrm{hr}$, TPRI was still reduced by $1.3 \pm 0.4 \quad(p<0.01 ; 0.3 \mathrm{mg} / \mathrm{kg})$ vs. an increase of $0.1+0.3$ (saline) mm Hg.min. $100 \mathrm{~g} \mathrm{bw/} \mathrm{ml.}$

Endralazine caused an tmmediate increase in CI and HR (fIg. 4.2) with a maximum reached within $30 \mathrm{~min}$. The increase in ci amounced to $3.7+0.4(p<0.001 ; 0.1 \mathrm{mg} / \mathrm{kg})$ and $4.5 \pm 1.1(p<0.001 ; 0.3 \mathrm{mg} / \mathrm{kg}) \mathrm{ml} / 100 \mathrm{~g}$ bw. HR increased by $5.7 \pm 15(p<0.001 ; 0.1 \mathrm{mg} / \mathrm{kg})$ and $70+15(p<0.001 ; 0.3$ $\mathrm{mg} / \mathrm{kg}$ ) beats $/ \mathrm{min}$. CI returned to control levels within $\mathrm{l} \mathrm{hr}$, whereas HR was back after $2 \mathrm{hr}$. No stgntflcant changes were observed with respect to SWI.

\subsubsection{Influence of baroreflex denervation on the central hemodynamic effects of hydralazine \\ Table 4.2 summarizes the baseline values for hemodynamic va-} rlables in the non-denervated SHR $(n=8)$ and the baroreflex-denervated animals $(n=7)$. MAP was significantly $(p<0.05)$ higher in the denervated SHR, due to a large increase $(p<0.001)$ in TPRI. HR was not significantly different, but CI and SVI were both signtflcant1y ( $<<0.001)$ lower in the denervated SHR. The maximal effects of $0.3 \mathrm{mg} / \mathrm{kg} \mathrm{hydra-}$ lazine 15-30 min after injection are given in fig. 4.3. Because of the 
Table 4.2: Babeline values (t SEM) jor hemodgmamic variables in the non-denembated and barorefiex-denemated SHR. Units: see table 4.1. Significance of the difference between the nomdenervated and denemuted animals: "p<0.05; "p<0.001.

\begin{tabular}{lcc}
\hline & $\begin{array}{c}\text { Non-denervated } \\
(\mathrm{n}=8)\end{array}$ & $\begin{array}{c}\text { Denervated } \\
(\mathrm{n}=7)\end{array}$ \\
\hline MAP & $156 \pm 3$ & $174 \pm 7^{*}$ \\
CI & $33.9+0.8$ & $23.8 \pm 1.2^{* *}$ \\
TPRI & $4.8+0.2$ & $7.4 \pm 0.3^{* *}$ \\
HIR & $402 \pm 12$ & $428 \pm 1.5$ \\
SVI & $84 \pm 5$ & $56 \pm 3^{* *}$ \\
\hline
\end{tabular}

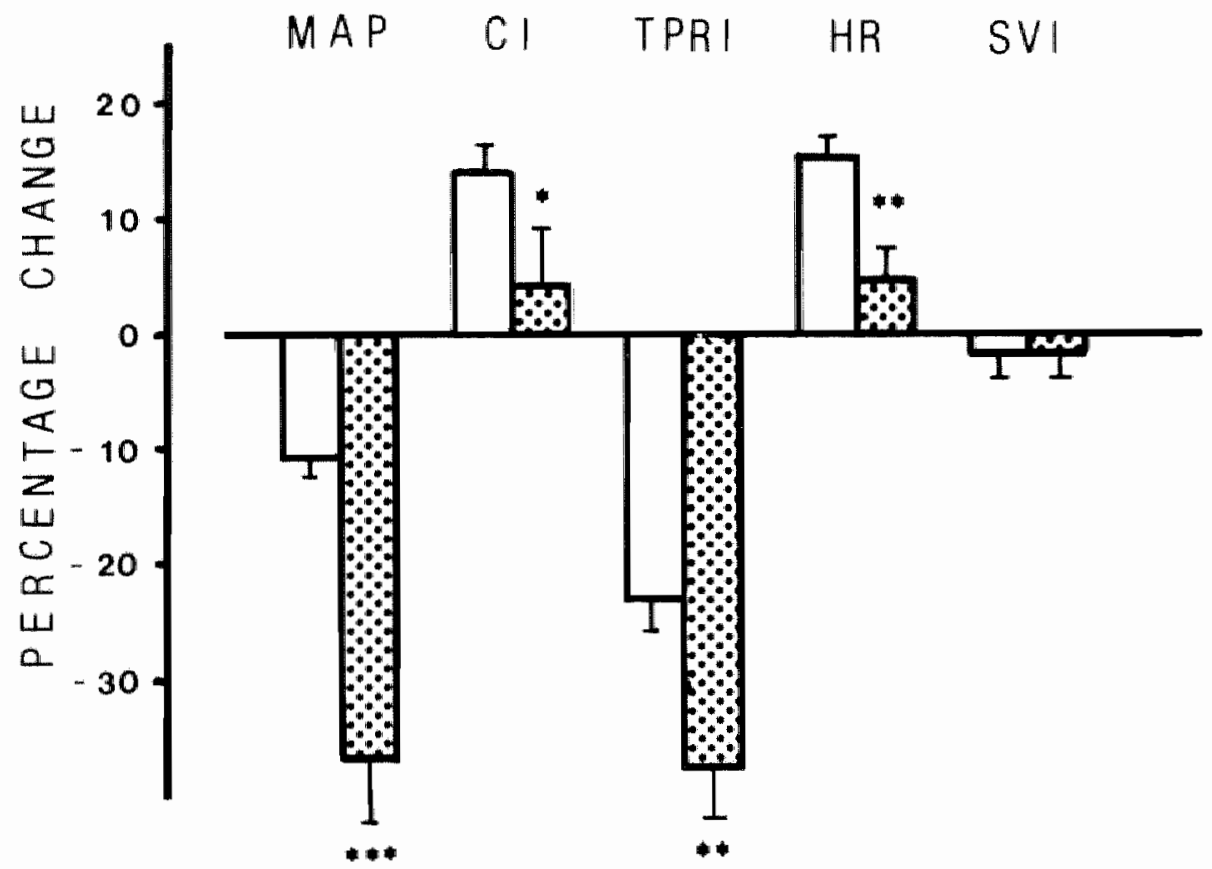

Fig. 4.3. Comparison of the masinat effeats of $0.3 \mathrm{mg} / \mathrm{kg}$ hydratarine in baroreceptor-denervated SBR (dotted bars) and in nondenervated SHR (open bars) on mean arterial pressure (MAP), ardiac index (CI), total peripheral restatance index $(T P R I)$, heart mate (HR), and stroke volume index (SVI). 
different baseline values, the effects are expressed as percentage changes. The fall in MAP was significantly ( $p<0.001$ ) larger than in non-denervated SHR $(-37+6$ vs. $-11+1 \%)$.

Similarly, the decrease in TPRI was larger fin the denervated animals $(-38+4$ vs. $-23+3 \% ;, 0<0.01)$. The early increase $1 \mathrm{n}$ CI was almost absent 1 in the denervated hydralazine injected animals ( $4+6$ vs. $14+2 \% ; \mathrm{p}<0.05)$. Tachycardia also was very slight in the denervated SHR $(5+3$ vs. $16+2 \%, p<0.01)$. There were no signiflcant changes in SVI In efther group.

4.3.4 Reglonal hemodynamic effects of hydralazine before and after baroreceptor denervation

Pre-injection values for MAP and HR in the different experimental groups used for the reglonal hemodynanles are sumarized in table 4.3 .

There were no statistically significant differences in control values of MAP and $k R$ between the saline and hydralazine-treated groups. In contrast to what observed in the central hemodynamic study, the baseline walue of MAP did not differ significantly in the two groups. In contrast, however, HR was significantly bigher in baroreceptor denervated animals than in intact anlmals.

The effects of hydralazine on reglonal hemodynamics in intact and denervated SHR are shown in fig. 4.4. Hydralazlne caused a dosedependent fall in MAP and an increase in HR with magnitudes and durations similar to those in the central hemodynamic expertments. Hind-

Table 4.3: Pme-injection values for MAP(m Hg) and HR(banl in the different experimentai groups. Significance of the differ ence between non-denemated and denemated animats: ${ }^{*} p \times 0.05$.

\begin{tabular}{|c|c|c|c|c|c|c|}
\hline & \multicolumn{3}{|c|}{ Non-denervated } & \multicolumn{3}{|c|}{ Denervated } \\
\hline & $\mathrm{n}$ & MAP & $\mathrm{HR}$ & n. & MAP & $\mathrm{MR}$ \\
\hline $0.9 \% \mathrm{NaCl}$ & 14 & $150+14$ & $327 \pm 26$ & 10 & $143+10$ & $354+12^{*}$ \\
\hline Bydralazlne & 11 & $145+14$ & $325+36$ & 10 & $155+24$ & $391 \pm 18^{*}$ \\
\hline
\end{tabular}


quarter and mesenterlc blood flow increased dose-dependently by respectively $48+17 \%$ and $22+14 \%$. Renal blood flow only s1lghtly increased after $0.3 \mathrm{mg} / \mathrm{kg}$ hydralazine $(+14+6 \%)$. The blood pressure reduction was parallelled by a decrease in renal, hindquarter and mesenteric resistance $(-24 \pm 8,-48 \pm 5$, and $-36 \pm 7 \%$ respectively after $1 \mathrm{mg} / \mathrm{kg}$ hydralazine). The reduction in HQR was signiflcantly greater than the fall in renal and mesentertc resistance after $1 \mathrm{mg} / \mathrm{kg}$ hydralazlne $(p<0.05)$. In denervated antmals the fall in MAP following hydralazine was significantly ( $p<0.001$ ) greater than in non-denervated SHR (maximally $51+4 \%$ 4s. $25+3 \%)$. The same was observed for the percentage reduction in renal $(p<0.05)$, hindquarter $(p<0.05)$ and mesenteric $(p<0.001)$ resistance. The tachycardia after hydralazine was not observed in the denervated SHR $(p<0.001)$.
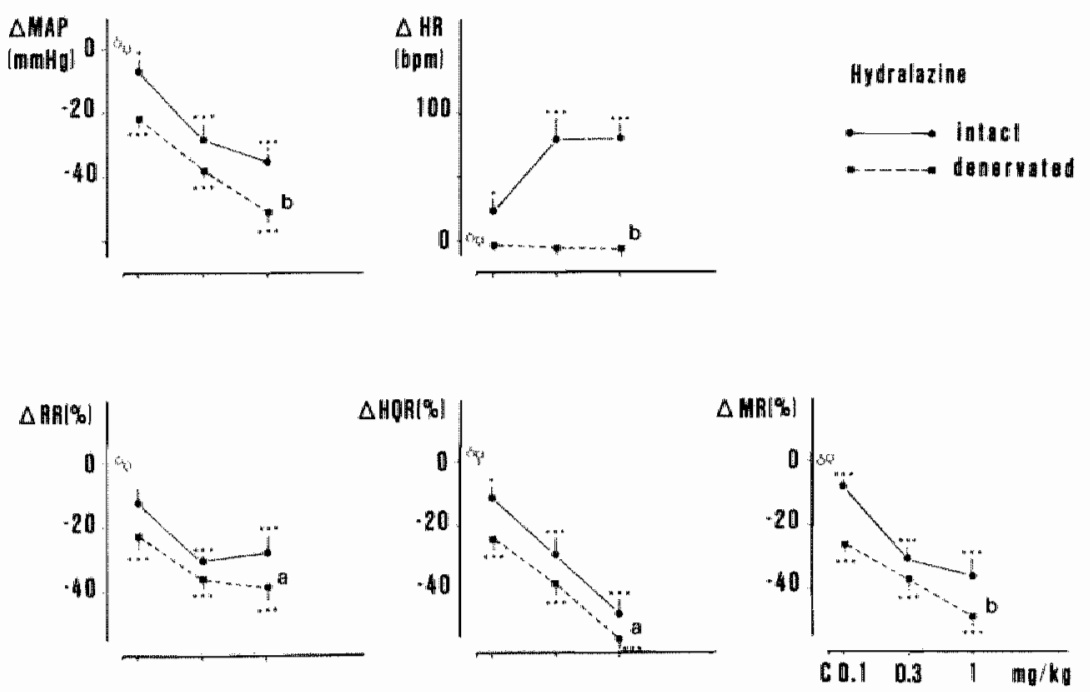

Fig. 4.4: Effect of various doees of hydralazine on mean arterial pressure (MAP), heart rate (HR), menal resistance (RR), hindquarter resistance (HQR) and mesenteric resistance (MR) in conscious intact and sinomartic denervated SHR. Significances are given in comparison with controt injections (** $* 0.001$ ), and in comparison with the vatues in the denemated anthals $(a=p<0.05 ; b=p<0.01)$. 


\subsection{Discussion}

The animal models used in thits study allow a continuous measurement of central and regional hemodymanic variables in unrestrained, consclous SHR. When studying hemodynamic effects induced by anthypertensive drugs, it is important to follow the changes with respect to time, preferably on a continuous basis. Moreover, in order to properly study the Influence of mervous reflex mechanlsms on drug-1nduced effects, the use of unanesthetized, undisturbed antmals is essential.

The present data confirm the long-standing conclusion on the primary hemodynamic effects of arteriolar vasodilators, like hydralaztne and dihydralazine (cf. Gross, 1977, for a detalled discussion). These agents cause an lmmediate fall in blood pressure with an underlying fall in total peripheral resistance. In this respect, these drugs behave differently Erom beta-adrenoceptor blockers or diuretics, the antihypertensive activity of which in the consclous SHR is associated with a fall in cardiac output, and even an increase in peripheral resistance (Smits et al, 1982; struyker Boudier et al, 1983b). In thls study we furthermore compared the hemodynamic effects of the new vasodilator endralazine to the activity of the arteriolar vasodllators hydralazine and dihydralazitne. Some early results on the experimental and clinical pharmacology of endralazine were published previously (Salzman et al, 1979; Kirch and Exthelm, 1982; E11tott et a1, 1982). On the basis of these studies, endralazine was characterized as an arteriolar vasodilator. Our studies confirm these results. Endrallatine 1s slightly more active than hydralazine. Its duration of action 1 s somewhat longer than that of hydralazine, an observation in agreenent with clinical data (E11tott et al, 1982).

The studies with Implanted Doppler flowprobes in consclous SHR Indlcate that the fall in total peripheral resistance after hydralazine is induced by a generalized reduction of resistance in the renal, hindquarter and mesenteric vascular bed wh a most pronounced effect in the skeletal muscle. The same regional hemodynantc pattern for hydralazine was observed by Maekawa et al (1984) 1n dogs using the microsphere technique. Recently, Chelly et al (1986) using Doppler flow probes in conscious dogs showed that hydralazine decreases coro- 
nary and renal reslstances. Furtherwore, Bolt and Saxena (1984a) observed a vasodilation in the heart, braln, kidneys and large intestwne but a vasoconstriction in skin, stomach and small intestine using the radloactive microsphere technique in hypertenstue rabblts. Only few systematic attempts have so far been made to distinguish between the senstivity of arterles of different vascular beds.

All vasodllators used in this study caused an increase in cardiac output and heart rate. We could not confirm an earlier conclusion (Salzman et a1 1979) that the reflex increase in cardiac output and heart rate for a glven fall in blood pressure is less after endralazine than after hydralazine. These effects have been related to a direct cardiac action of the vasodilators (Khatri et a1, 1977; Wend11ng et all, 1979) or to a reflex-mediated increase in sympathetic activity (W1drio and Tena, 1980, Perez et al, 1982). The present study clearly supports the concept of a baroreflex mediated increase in gympathetic nerve activity. Any given dose of hydralazine caused a signiflcantly larger fall in blood pressure and peripheral resistance In the SHR without baroreflex control than in the non-denervated animals. Sigaticantly larger falls in reglonal resistances after denervation were found in all 3 vascular beds studied. These results indicate that the general vasodilation seen in intact animals after hydralaztne is an additive effect of a strong direct vasodilation by hydralazine and a vasoconstriction induced by baroreceptor reflex desactivation (see chapter 3 ). The remaining small increase in cardiac output and heart rate in the central herwodynamlc groups might have been caused elther by a slight direct positive chronotroplc effect of hydralazine (Pérez et al, 1982).

In the central hemodynamic studies, surgical afferent denervation of the baroreceptor reflex led to a silght further increase in blood pressure in the SHR, in comblnation with an increase in total peripheral restatance. This observation agrees with earlier results in baromeceptor-denervated normotensive rats (Krieger, 1967), rabbits (Alexander and Dequattro, 1974), and foxhounds in which the baroreflex was deafferentated by lesions of the nucleus tractus solftar11 (NTS) In the brain stem (Carey et al, 1979). Cardlac output and stroke volume were even significantly reduced after baroreflex denervation. A 
similar observation was made by Carey et al (1979) in the MTS-1esioned foxhound. These reductions in cardiac output and stroke wolume are probably related to an increased afterload (Braunwald et al, 1967).

In the regional hemodynamic studies, the pre-injection values show that sino-aortic denervation does not lead to a further elevation in blood pressure in consclous SHR. Blood pressure was much more labile in these animals and heart rate was signiflcantly higher. This effect of denerwation was also observed in the other reglonal hemodynamlc studies described in this thests, indicating that the animal preparation might be involved. Possibly, the baroreceptors on the aortic arch are better denervated ta the central hemodymamic studies as a consequence of the electromagnetic flow probe fmplantation on the ascending aortic arch where baroreceptors are located.

The reflex increases in cardlac output and heart rate after the administration of the arteriolar vasodilators were of short duration in comparison to the prolonged decrease in blood pressure. Whereas the Eall In blood pressure lasted for up to $24 \mathrm{hr}$, reflex Increases in cardiac output and heart rate were observed only for 1 to 2 hr at most. These data point to a rapid disappearance of the baroceflexmedlated increased sympathetic tone. This rapld waning of baroreceptor Influences could be related to the adaptation of the baroreceptor reflex. The effects on $C I, H R$ and SVI measured $1 n$ sino-aortic baroreceptor denervated animals were almost comparabele with the effects measured 2 hr after hydralazine in intact animals. These results support the hypothesis of a rapid baroreflex adaptation. However, a signiflcant stronger reduction In TPRI was observed in denervated as compared to intact antmals. So we would expect that TPRI further decreased during the $2 \mathrm{hr}$ after the bolus injection of hydralaztne. This was not observed in our central hemodynamic studies. These results indicate a different baroreflex resetting time for the heart and the blood vessels induced by hydralazine. A rapld adaptation thas been reported to occur within several hours in the consclous rat (Salgado and Krieger, 1978). It has prevlously been shown that rapid baroreflex adaptation is also involved in the early hemodynamic changes after propranolol in the consclous SHR (Struyker Boudier et al, 1979; Smits et $\mathrm{a} 1,1980 \mathrm{~b}, 1982)$. If the baroreflex adapts to a vasodilator 1 nduced 
fall in blood pressure, this might have important clinical consequences for chrontc use of rasodilators. In hypertensive patients, it is also posstble that the early increases in cardiac output and heart rate might disappear eventually during the long-term use of such agents. Indrect evidence for such a phenomenon in hypertensive pathents was provided by Brunner et al (1978) who showed a reduced need For beta-adrenoceptor blockade in patients who were treated for several months th the arterlolar vasodilator moxidil. A major problem In the hemodynamic analysis of such long-term effects of vasodilators is that these drugs are always administered in combination with other antihypertensfyes. It could therefore be of relevance to repeat aur studieg under conditions of long-term administration of vasodilators In conscious SHR. Long-term regional hemodynamic effects of a hydralazine-11ke substance, CGP 18 137A, are described in chapter 6 of this thesis.

In addition to the baroreflex-mediated changes in autonomic nerve activity, a change in plasma renin concentration (PRC) may affect the hemodynamic responses to arterlolar vasodilators. Thus, arterlolar vasodllators increase PRC, elther through reflex activation of the sympathetic nervous system or through a dilrect renal effect of the reduced artertal pressure (Koch-Weser, 1974; Gross, 1977). It cannot be excluded that the larger fall in MAP and TPRI which we observed in baroreflex-denervated SHR as compared to the fall in Intact rats after hydralazine was partly related to a smaller degree of reflex activation of PRC.

It Is still not clear by what mechanism hydralazine and related substances reduce peripheral resistance and whether this mechanism $1 \mathrm{~s}$ similar in all vascular beds. Some investigators suggested a direct effect on arterlolar swooth muscle (Gross et al, 1950; Khayal et al, 1981). Indirect mechanlsms have also recelved some attention, e.g. interference with sympathetic linnervation of arteriolar smooth muscle (Worcel et a1, 1980) or enhanced release of endogenous vasodilator prostaglandins (Haeusler and Gerold, 1979). The data of Chelly et al (1986) who used a cyclo-oxygenase inhibitor in combination with flow measurements, Indicate that the renal vasodilation after hydralazine is dependent upon the prostaglandin system. Furthermore, they did not 
find a hydralazine-induced coronary vasodllation after blocking the baroreflex pathway, suggesting that the coronary vasodilation is related to an increase in myocardial oxygen demand. Meakawa et al (1984) observed that prostaglandins have their major effect on the splanchnic and renal circulation. Pre-treatment with a cyclo-oxygenase Inhibitor led to an increase in renal and mesenteric resistance after hydralazine. These data may indicate that the vascular effects of hydralaztne are partly mediated by effects on the prostaglandin synthesis. Meakawa et al (1984) suggested the involvement of alpha-adrenergic constriction and beta-adrenergic dllatation in the vascular effects of hydralazine. Possibly, several of these mechanisms are involved in the hemodynamic effects of hydralazlne. The present study was not designed to further elucidate the cellular or subcellular mode of action of the classical vasodilators. 

CHAPTER 5

HEMODYNAMIC EFFECTS OF CALCIUM ENTRY BLOCKERS IN CONSCIOUS SHR.

\section{$5.1 \quad$ Introduction}

In recent years, calclum entry blockers (CEBs) have gained recognition in the treatment of hypertensive disease. Calclum entry blockers, such as verapamil and nifedipine, effectively lower blood pressure in hypertensive patients (Guazzl et al, 1977; Kowskl et al, 1983) and in various hypertenstve antmal models, including the SHR (Ishif et al, 1980; Lederballe Pedersen et al, 1982; Takata and Hutchinson, 1983). It is generally supposed that the blockade of calclum entry into vascular smooth muscle cells leads to a decrease in calcium dependent sympathetic or hormonal induced vascular tone, reducing vascular resistance. Recent clinfcal studies have fndeed shown that the fall in blood pressure during therapy with nffedipine was assoclated with a fall in total vascular resistance (Mcleay et al, 1983; Kilawsi et al, 1983). Gross et al (1979) showed that nifedipine also reduced total vascular resistance in consclous normotensive dogs. A similar reduction in total peripheral resistance reductions was observed for several calcium entry blockers by Hof (1983) in anesthetlzed normotensive cats. Flaim and Zelis (1982) and Kanda et al (1984) observed a reduction of total peripheral resistance in consclous normotensive rats, following the calclum entry blockers diltiazem and nifediplne. Thus, mostly only normotenstve animal models have so far been used to study the hemodynamic effects of calctum entry blockers. Since several authors have reported much more pronounced anthypertensive responses to calcium entry blockers in consclous SHR than in normotensive rats (Ishii et al, 1980; Takata and Hutchinson, 1983) it 
seened of interest to study the hemodynamic effects of ealcium entry blackers in the hypertensive antal model.

In chapter 1, we sumarized the regional hemodynanic effects of calclum entry blockers "In these studies, reglonal flow changes were mathly measured in normotensive consclous and anesthetized antmals using the microsphere techolque. Most of these studies show that calcium entry blockers decrease coronary, cerebral and muscular vascular resistance. In the other vascular beds, the reglonal effects are much more divergent in response to calclum entry blockers (see chapter 3).

The second purpose of the present study was to determine reglonal hemodynamlc actlons of the calcium entry blockers verapaml, nifediplne and PY 108-068. We also studied the effects of nifedipine on reglonal hemodynamics in WKY rats to check possible selectivity of CEBs for SHR. For thils purpose, the rats were chronically instrumented with Doppler flowprobes to allow reglonal flow measurements.

We have previously shown that acute hemodynamic effects of antihypertensive agents as beta-blockers (Struyker Boudier et al, 1979) and classical vasodilators (see chapter 4 of this thesis) in consclous SHR are strongly influenced by sino-aortic baroreceptor reflexes. Barron et al (1983) reported that reglonal vasodilator responses to calcium entry blockers in normotensive rats were also strongly influenced by these reflexes. Therefore, as a thitd purpose of this study, we compared the regional hemodynamic effects of calcium entry blockers in intact and in sino-aortic baroreceptor denervated SHR to study fnteractions of the sino-aortic baroreflex with the effects of these drugs in SHR.

In the long-term, the influence of baroreceptor reflex mechanlsms may be less dominant because of adaptation of these mechanisms to the prevalling level of blood pressure (Smits et a1, 1982; Struyker Boudier, 1984). During long-term treatment, possibly the renin-anglotensia-aldosterone system could influence the reglonal hemodynamics of CEBs. Therefore, a last aspect of our study with CEBs was to investigate their effects upon chronlc application. In these studies, long-term effects of verapamil on plasma renin concentration and regional hemodynamics were determined. 


\subsection{Materials and methods}

\subsubsection{Antmals}

Male SHR and normotensive Wistar Kyoto (WKY) rats, welghing 260-320 g, were used. More detalls are described in section 2.1.

\subsubsection{Experimental protacol acute studies}

Systemic hemodynamic effects of CEBs were determined in intact SHR. Reglonal hemodynamics were measured in intact SHR and WKY rats and in baroreceptor denervated SHR. Surgery and measurements for the central and regional hemodynamic studies are described in paragraph 2.3 and 2.4 respectively. The baroreceptor denervation was performed as described in section 2.6 of this thesis.

On the day of the experiments, the animals were placed in experimental cages between 9:00 and 10:00 a.m. They were allowed to habituate to the experimental conditions for at least $1 \mathrm{hr}$. Pre-injection values were obtalned as the average of 4 readings at 5 min intervals 1 in the last $20 \mathrm{~min}$ before an injection. Drugs were injected i.v. In $0.1 \mathrm{ml} 0.9 \% \mathrm{NaCl}$ (saline) in the case of verapand1 or $0.1 \mathrm{ml}$ of a mixture of polyethylene glycol (PEG), ethanol and $0.9 \% \mathrm{NaCl}(\mathrm{v} / \mathrm{v} / \mathrm{v}$, $1 / 1 / 2)$ in the case of nifedipine and PY 108-068. Injections of solvent or different drug concentrations were given in random order. Hemodynamic variables were recorded continuously for at least 2 hr following injections. Effects were measured as differences from the pre-injection values.

\subsubsection{Experimental protocol long-term studies}

\subsubsection{Reglonal hemodynamic measurements}

In the long-term regional hemodynamic studies, surgery and measurements were perforned as in the acute studies. However, the drug was not administered as a bolus injection via the femoral veln catheter, but as a continuous infusion using Alzet ${ }^{\text {TM }}$ osmotic minlpumps via the jugular veln catheter. MAP, HR, RF, MF and HQF were measured every day (during $\pm 1.5 \mathrm{hr}$ ) from one day before unt 115 days after the start of the infusion. The lnfusion was started by connectling the drug containing minlpump under light ether anesthesla to the jugular vein 


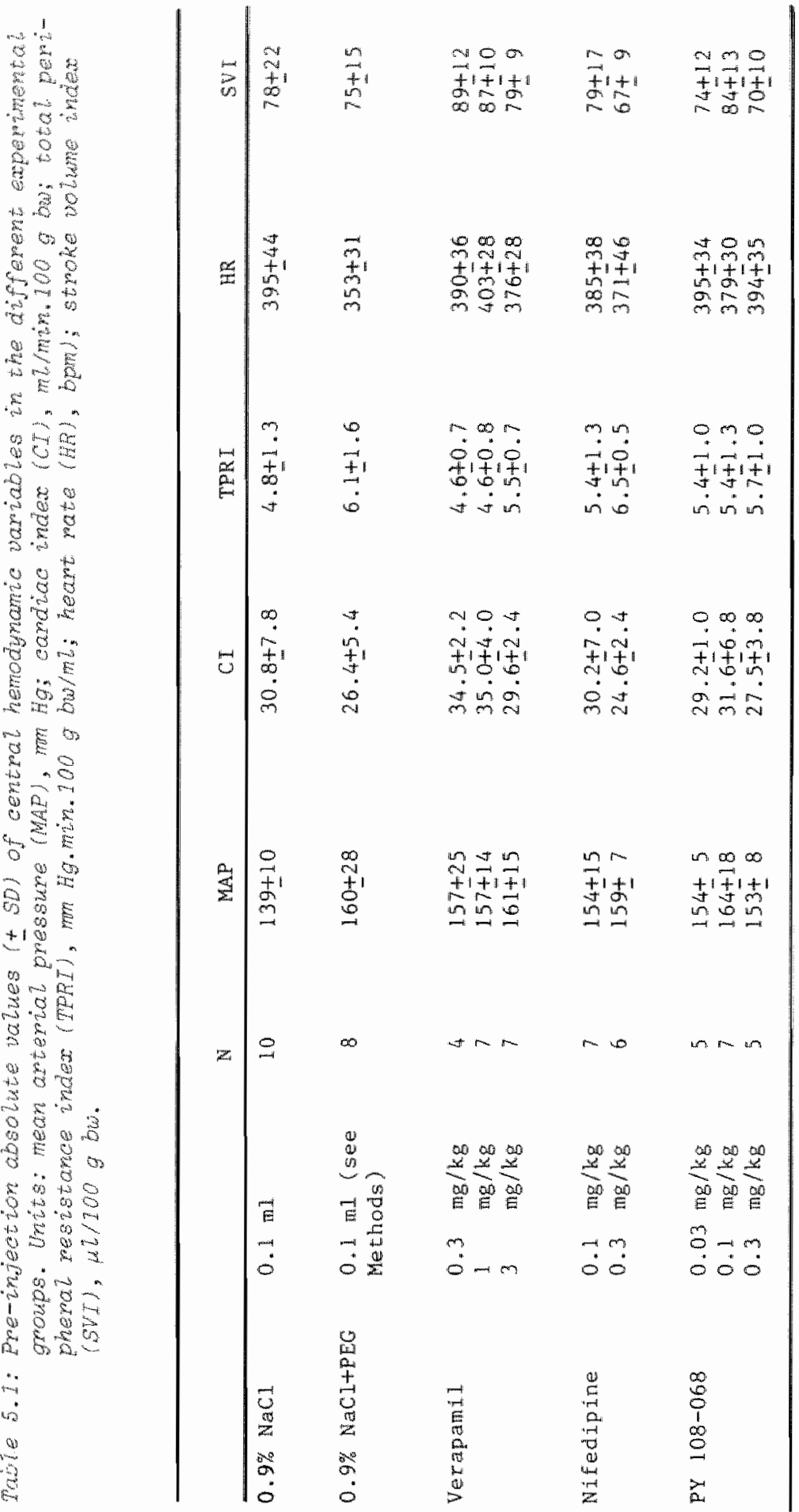


catheter and implanting it under the skin of the rat. The effects sre expressed as percentage change from pre-infusion values on day 0 .

\subsubsection{Plasma renin concentration measurements}

The SHR used in this study were implanted with an abdoninal aorta catheter and a jugular velin catheter one day before the start of the experinent. Via the catheter in the abdominal aorta, MAP and HR were measured and blood samples were collected fust before and afer a 4 days infusion period. Verapamil (10 mg/kg.d) was administered via a jugular vein catheter using an Alzet ${ }^{\mathrm{TM}}$ minipump. The plasma renin concentration in these blood samples was quantitated as described in section 2.7 .

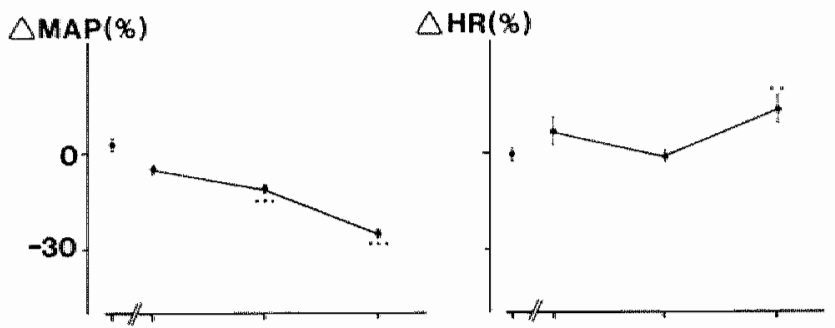

VERAPAMIIL

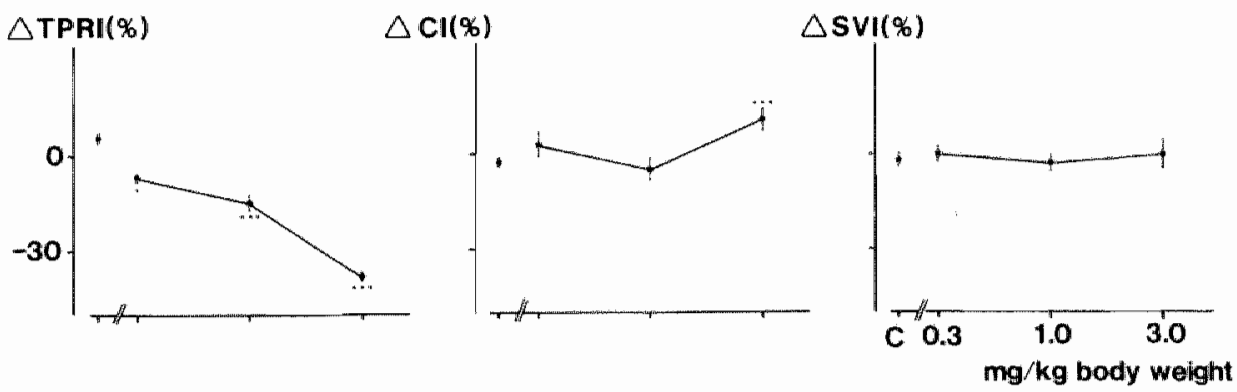

Fig. 5.1: Effecte of various doses of verapamiz on mean arterial pressure (MAP), heart rate (HR), total peripheral reaistance index (TPRI), cardiac index (CI), and stroke volune index (SVI) in concoious SHR. Significances are given in comparicon to control injections (C) $(* p<0.05 ; * p<0.01$; * * $p$ $0.001 ; n=4-7)$. 


\subsection{Regults}

\subsubsection{Acute atudies}

\subsubsection{Central hemodynamic studies}

Pre-infection values for the different hemodynamic variables are summarized in table 5.1. The maximal effects of the three calcium entry blockers are shown in flgs. 5.1-5.3. Saline and the solvent for nffediplne and PY 108-068 caused only minor hemodynanic changes.

All three agents caused a rapld fall in MAP and TPRI. These effects reached their maximum within 5-10 min after injection and the magnitude of the effects was dose-dependent. PY 108-068 was the most potent agent, causing a reduction 1 M MAP of $36+2 \%$ and TPRI of $52 \pm 1 \%$ at a dose of $0.3 \mathrm{mg} / \mathrm{kg}$. Nifediplne at a dose of $0.3 \mathrm{mg} / \mathrm{kg}$ caused a maxi-
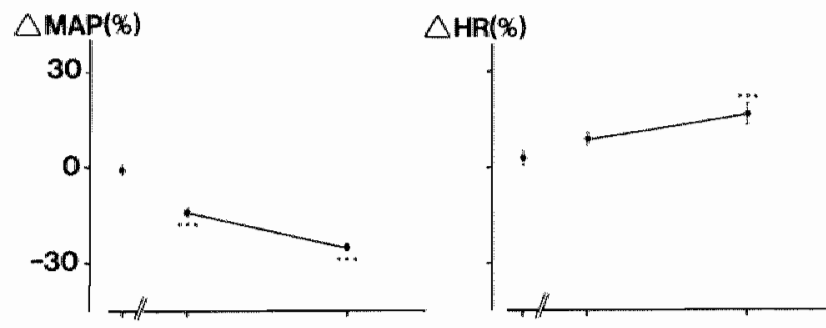

\section{NIFEDIPINE}
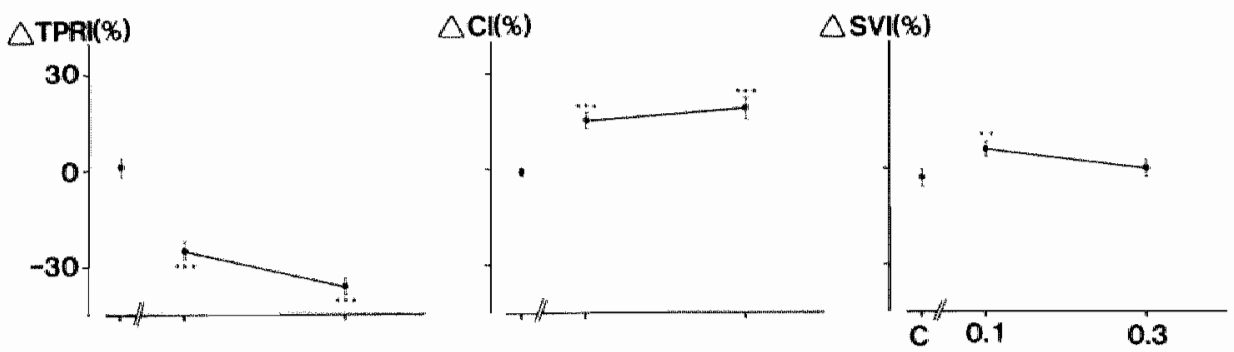

$\mathrm{mg} / \mathrm{kg}$ body weight

Fig. 5.2: Effects of various doses of nifedipine on mean arterial pressure (MAP), heart mate (HR), total peripheral resistance index (TPRI), cardiac index (CI), and stroke volume index (SVI) in conscious SHR. Significance are given in comparison to control injections $(C)\left(* * 0<0.01 ; * *{ }^{*} p<0.001 ; n=6-7\right)$. 
wal MAP decrease of $25+1 \%$ and of $36+3 \%$ for TPRE. Similar effects were obtained at a dose of $3.0 \mathrm{mg} / \mathrm{kg}$ verapamil (MAP: $-25+2 \%$; TPRI: $-38+1 \%$ ). Depending upon the dose, the fall $1 \mathrm{n}$ MAP and TPRI lasted 0.5-2 hr.

The effects on HR and CI differed for the three calctum entry blockers. In the case of verapamil, no significant changes were observed in these varfables after infection of 0.3 and $1.0 \mathrm{mg} / \mathrm{kg}$. Only at the highest dose of $3.0 \mathrm{mg} / \mathrm{kg}$ significant $(p<0.01)$ increases of $14+4 \%$ and $11+4 \%$ were observed for $H R$ and CI. Nifediptne and PY 108-068 Induced a rise in HR and CI at both doses $(0.1$ and $0.3 \mathrm{mg} / \mathrm{kg})$ that caused a significant fall in MAP (flgs. 5.2 and 5.3).

None of the three calctum entry blockers caused a significant change in SVI except for a small, but significant (p<0.01) increase $(6+1.8 \%)$ after the lower dose of nifedipine $(0.1 \mathrm{mg} / \mathrm{kg}$, fig. 5.2$)$.
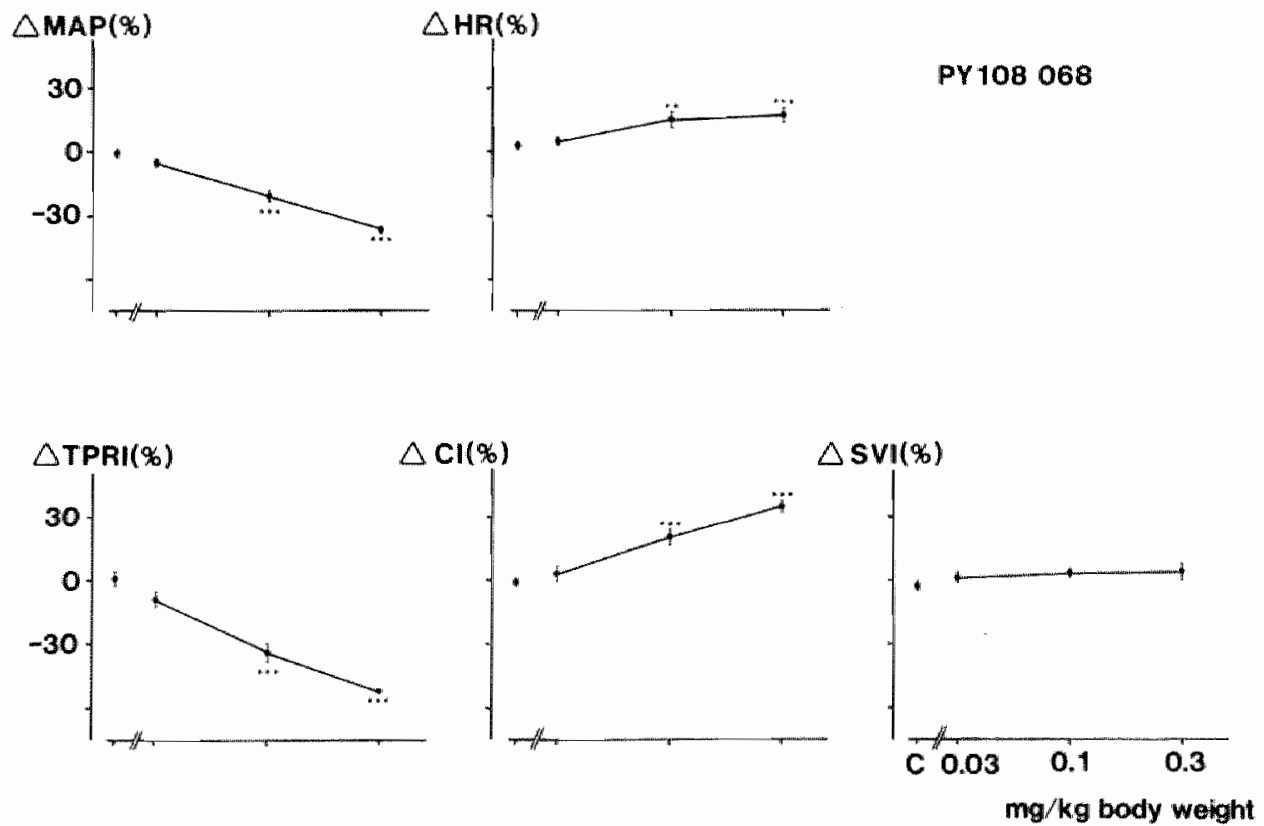

Pig. 5.3: Effecte of various doses of $P Y$ 108-068 on mean arterial pressure (MAP), heart rate (HR), total peripheral resistance index (PPRI), cardiac index (CI), and atroke votume index (SVI) in conscious SHR. Signifiadnces are given in comparicon to control injections (C) (**p<0.01; **p<0.001; $n=5-7)$. 
Table 5.2: Pre-injection aboolute values (t SD) of mean arterial preasure (MAP. ming and heart rate (HR, bpm) in the different experimental groupe used in the regional hemadynomic expemente.

\begin{tabular}{|c|c|c|c|c|c|}
\hline & & & $\mathrm{N}$ & MAP & HR \\
\hline $0.9 \% \mathrm{NaCl}$ & $0.1=$ & $\mathrm{ml}$ & 7 & $152 \pm 18$ & $350+25$ \\
\hline $0.9 \% \mathrm{NaCl}+\mathrm{PEG}$ & $\begin{array}{l}0.1 \\
\text { Metho }\end{array}$ & $\begin{array}{l}\text { m1 (see } \\
\text { ods) }\end{array}$ & 7 & $167+19$ & $311+33$ \\
\hline Verapamil & $\begin{array}{l}0.3 \\
1 \\
3 \\
10\end{array}$ & $\begin{array}{l}\mathrm{mg} / \mathrm{kg} \\
\mathrm{mg} / \mathrm{kg} \\
\mathrm{mg} / \mathrm{kg} \\
\mathrm{mg} / \mathrm{kg}\end{array}$ & $\begin{array}{l}12 \\
14 \\
12 \\
11\end{array}$ & $\begin{array}{l}137+19 \\
132+16 \\
132+15 \\
128+15\end{array}$ & $\begin{array}{l}342+44 \\
326 \mp 41 \\
325+38 \\
335+36\end{array}$ \\
\hline N1 fediplne & $\begin{array}{l}0.1 \\
0.3 \\
1\end{array}$ & $\begin{array}{l}\mathrm{mg} / \mathrm{kg} \\
\mathrm{mg} / \mathrm{kg} \\
\mathrm{mg} / \mathrm{kg}\end{array}$ & $\begin{array}{l}7 \\
7 \\
8\end{array}$ & $\begin{array}{l}140+9 \\
140+19 \\
130 \pm 8\end{array}$ & $\begin{array}{l}343+48 \\
355+31 \\
359+41\end{array}$ \\
\hline$P Y 108-068$ & $\begin{array}{l}0.01 \\
0.03 \\
0.1 \\
0.3 \\
1\end{array}$ & $\begin{array}{l}\mathrm{mg} / \mathrm{kg} \\
\mathrm{mg} / \mathrm{kg} \\
\mathrm{mg} / \mathrm{kg} \\
\mathrm{mg} / \mathrm{kg} \\
\mathrm{mg} / \mathrm{kg}\end{array}$ & $\begin{array}{l}4 \\
8 \\
8 \\
8 \\
7\end{array}$ & $\begin{array}{l}163+14 \\
153+21 \\
146+19 \\
139+16 \\
139+17\end{array}$ & $\begin{array}{l}328+40 \\
331+22 \\
330+32 \\
328+25 \\
336+34\end{array}$ \\
\hline
\end{tabular}

\subsubsection{Reglonal hemodynamle studies}

\section{Spontaneously hypertensive rats}

Pre-injection values for MAP and HR for the different experimental groups are sumarized In table 5.2 and the effects of the three calcium entry blockers on reglonal hemodynamics are shown in figs. 5.4-5.6. The three drugs caused a fall in MAP, of simflar magnitude and duration as those in the systemic hemodynamic experiments. Verapawill was without effect on HR in these experiments also, even at the higher doses. Nifedipine and PY 108-068 caused a dose-dependent rise in HR, of similar magnttude and duration as those in the central hemodynamic experiments.

In splte of the profound blood pressure reductions, none of the calcium entry blockers decreased hindquarter blood flow (HQF). PY 108-068 even slightly increased $H Q F$ (maxlmally $+9.6 \pm 4.1 \%$ after 0.3 
mg/kg). Thus, all three calcium entry blockers reduced HQR in parallel. to the fall in MAP. At the highest doses, the fall in HQR amounted to $20+5 \%$ for verapamil (10 mg/kg; p<0.001), $24+5 \%$ for nifedipine $(1.0$ $\mathrm{mg} / \mathrm{kg} ; \mathrm{p}<0.001)$ and $24+5 \%$ for $P Y 108-068(1.0 \mathrm{mg} / \mathrm{kg} ; \mathrm{p}<0.001)$. Vasodilation was maximal at 5-15 min after injection and lasted $0.5-2 \mathrm{hr}$, depending upon the dose injected. Mesenteric flow (MF) decreased in parallel to the fall in MAP. Thus, at the highest doses, the flow reductions in the mesenterlc bed were $32+7 \%$ (verapamil), $11+5 \%$ (nifedipIne), and $38+7 \%$ (PY 108-068). Calculation of MR showed that none of the drugs significantly altered this parameter. Nifedipine caused a consistent but non-significant reduction of $M R$ (fig. 5.5). At low doses, verapamil ( $\mathrm{fig}$. 5.4) and PY 108-068 (fig. 5.6) did not change MR, whereas at higher doses, both drugs increased MR. A more complex

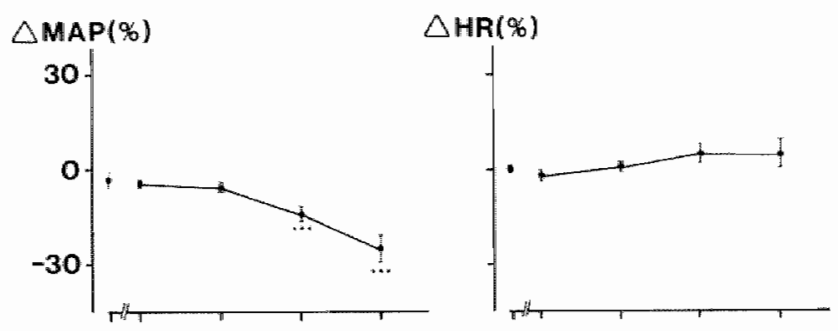

\section{VERAPAMIL}

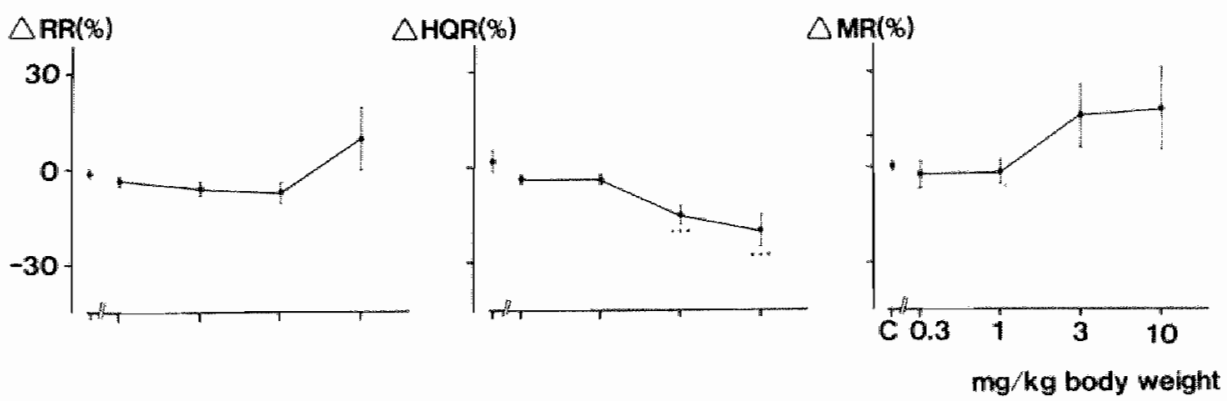

Pig. 5.4: Effect of various doses of verapamiz on mean arterial pressure (MAP), heart mate (HR), renal resistance (RR), hindquarter meistance (HQR), and mesenteric resistance (MR) in conscious SAR. Significances are given in compamioon to control injections (C) (***0<0.001; $n=6-14)$. 
plcture wabtalned for renal hemodynamics. Verapamil and nifedipine conglstently lowexed renal flow (R.F), resulting in unchanged RR. At low doses $(0.03$ and $0.1 \mathrm{mg} / \mathrm{kg})$, PY 108-068 did not 1nfluence RF, whereas these doses lowered MA.P. Thus, RR was decreased by $13+4 \%$ ( $p<0.01)$ and $12+1 \%(p<0.01)$ after 0.03 respectively $0.1 \mathrm{mg} / \mathrm{kg}$. This effect was no longer observed after the higher doses (fig. 5.6).

\section{Normotensive Histar Kyoto rats}

In order to check for possible selectivity of the reglonal hemodynamic effects of calclum entry blockers for SHR, we studied the effects of nifedipine $(0.1-\mathrm{l} \mathrm{mg} / \mathrm{kg})$ and its solvent in a group of 6 WKY rats. Pre-1njectlon MAP ranged from $105-120 \mathrm{~mm} \mathrm{Hg}$ and $\mathrm{HR}$ from
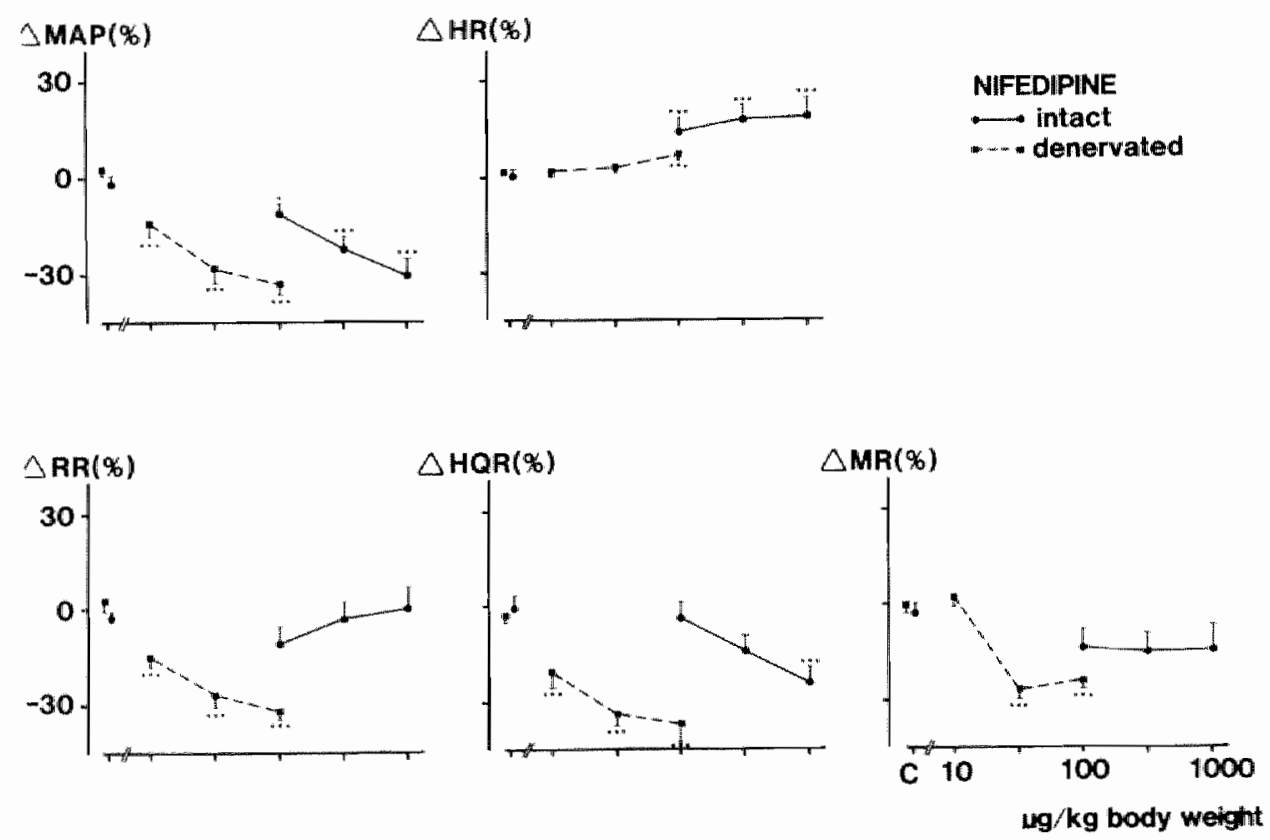

Fig. 5.5: Effects of various doses of nifedipine on mean amberial pressure (MAP), heart rate (HR), renat resistance (RR), hindquarter resistance (HQR), and mesenteric resistance (MR) in consoious intact and ino-aontic denervated SHR. Signifiances are given in comparison to control injections (C) $(* * * 00.001 ; \quad n=6-8)$. 
300-360 bpm/min in these animals. Nifedipine caused a doge-dependent fall in MAP with a maximum reduction of $22+2 \%$ ( $p<0.001$; vs. $-1 \pm 1 \%$ after solvent) and an Increase in $\mathrm{HR}$ of $28+3 \%(\mathrm{p}<0.001 ; \mathrm{vs} .+2+2 \%$ after solvent) at a dose of $1 \mathrm{mg} / \mathrm{kg}$ At this dose, $\mathbb{R F}$ and $M F$ decreased by $33+5 \%$ and $14+3 \%$. On the other hand, HQF increased by $29+13 \%$. Calculation of the resistance indicates a non-significant change in $R \cdot R$ $(+19+9 \%)$ and $M R(-9+5 \%)$. HQR, on the other hand, was reduced significantly by $-38+8 \%$ ( $p<0.001$ vs. $+2+3 \%$ after solvent).

\subsubsection{Influence of sino-aortic baroreceptor denervation on regional hemodynamics \\ Since the reglonal hemodynamic effects of verapamil and nife-}
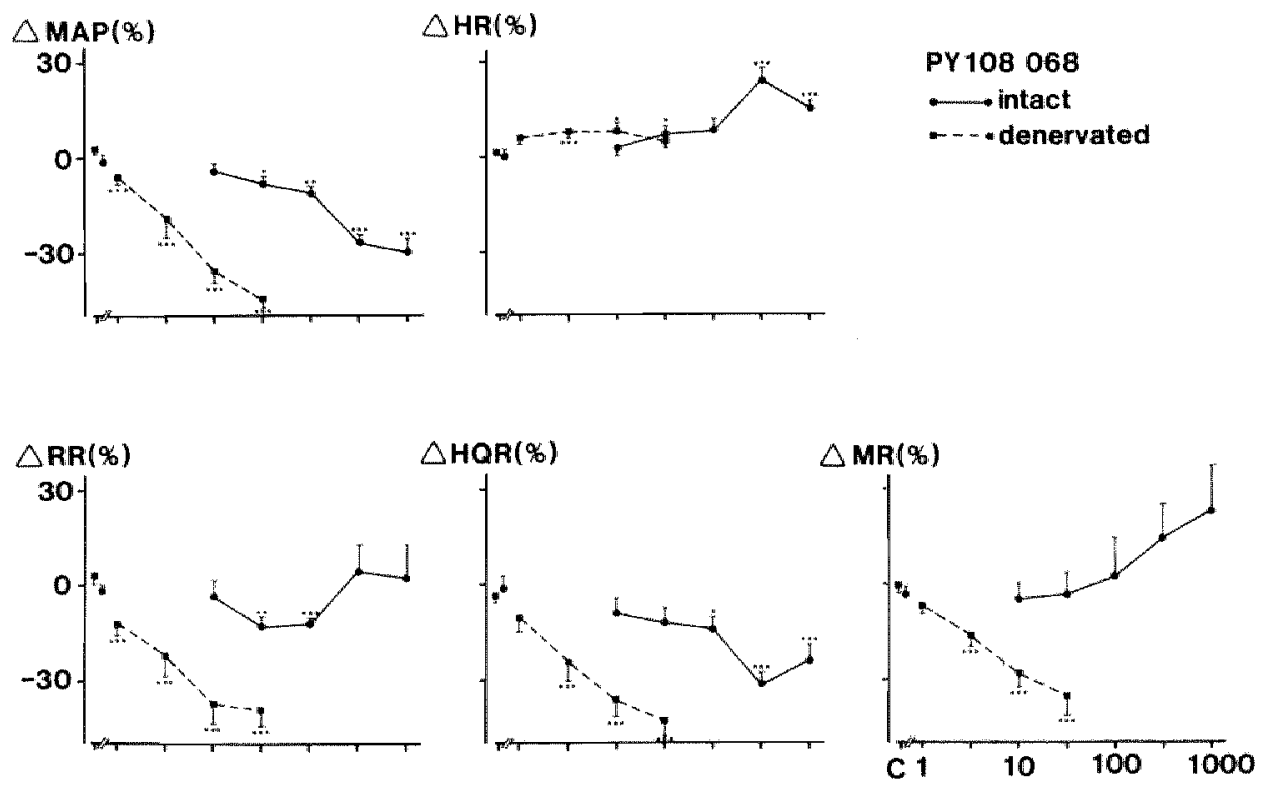

$\mu \mathrm{gg} / \mathrm{kg}$ body weight

Fig. 5.6: Effects of various doses of $P Y$ 108-068 on mean arterial presiure (MAP), heart rate (HR), renal resibtance (RR), hindquarter reaistance (HQR), and mesenteric resistance (MR) in consciows intact and sino-aortic denervated SHR. Significances are given in comparison to control injections (C) (*p<0.05;**p<0.01;***p<0.001; $n=4-8)$. 
dipine were very simlat, we studled the influence of baroreceptor denervation only for nifediplne and PY 108-068. The pre-injection values For MAP and HR in the difterent groups used in this experiment are given in table 5.3 .

Tabie 5.3: Pre-ingection absolute valueg (t SD) of mean amterial preseure (MAP, mim $H g$ l and heart rate (HR, bpm) in the different aino-aomic denervated SHR used in the regional herodyanto experiments.

\begin{tabular}{|c|c|c|c|c|c|}
\hline & & & $N$ & MAP & $\mathrm{HR}$ \\
\hline \multicolumn{3}{|c|}{$\begin{array}{l}0.9 \% \text { NaC1 + PEG } \\
\text { (see Methods) }\end{array}$} & 9 & $159+24$ & $371+44$ \\
\hline Nifediplne & $\begin{array}{l}10 \\
30 \\
100\end{array}$ & $\begin{array}{l}\mu \mathrm{g} / \mathrm{kg} \\
\mu \mathrm{g} / \mathrm{kg} \\
\mu \mathrm{g} / \mathrm{kg}\end{array}$ & $\begin{array}{l}7 \\
7 \\
7\end{array}$ & $\begin{array}{l}166+28 \\
162+20 \\
1.42+19\end{array}$ & $\begin{array}{l}392+56 \\
387 \pm 50 \\
393 \pm 31\end{array}$ \\
\hline PY 108-068 & $\begin{array}{l}1 \\
3 \\
10 \\
30\end{array}$ & $\begin{array}{l}\mu \mathrm{g} / \mathrm{kg} \\
\mu \mathrm{g} / \mathrm{kg} \\
\mu \mathrm{g} / \mathrm{kg} \\
\mu \mathrm{g} / \mathrm{kg}\end{array}$ & $\begin{array}{l}5 \\
6 \\
6 \\
6\end{array}$ & $\begin{array}{l}146+18 \\
156+32 \\
152+31 \\
148+33\end{array}$ & $\begin{array}{l}378+35 \\
354+15 \\
349+12 \\
344+10\end{array}$ \\
\hline
\end{tabular}

Pllot experiments indicated that sino-aortic denervated SHR were much more sensitive than non-denervated antmals to the blood pressure lowerting effect of calctum entry blackers. Therefore, the range of doses tmvest 1 gated was 10-fold lower than that in the prevlous experiment. Agaln, both nifedtpine (fIg. 5.5) and PY 108-068 (fig. 5.6) caused a dose-dependent fall in MAP. The maximal effects in these antalls accurred within 2 inta after injection. When compared with the respective non-denervated groups (figs. 5.5 and 5.6), the dose-response curves for the maximal effects were shifted to the left on the dose axis by a factor of 10 . The denervated animals showed only a sma11 degree of tachycardla. For a comparable fall in MAP, the increase in HR was much less in the denervated animals $(e . \mathrm{g} .1 \mathrm{mg} / \mathrm{kg}$ nifediptne in non-denervated SHR: MAP $-30+5 \% ; H R:+19+3 \% \mathrm{vs} .0 .1 \mathrm{mg} / \mathrm{kg}$ in denervated SHR: MAP $-32+3 \% ; H R:+7+1 \%)$. 
Regional hemodynamic measurements in baroreceptor denervated animals Indicate a generallzed vasodilation in parallel with the fall in MAP. The relative decrease in MAP corresponded closely to the fall In vascular resistance in the three vascular beds for all doses of nifediplne and PY 108-068.

\subsubsection{Long-term studies}

\subsubsection{Effect on reglonal hemodynamics}

Pre-infusion values of MAP (mm Hg) and $H R(b p m)$ for the saline $(0.9 \% \mathrm{NaCl})$ and the verapant $1(10 \mathrm{mg} / \mathrm{kg} \cdot \mathrm{d})$ treated groups, just before the start of the Infusion, on day 0 , are summariged in table 5.4 .

Table 5.4: Pre-infusion values of MAP (m Hg) and HR (bpm) for the different experimental groupe in the tong-tem regional hemodymamic study. Data are expressed as means $\pm S E M$.
n
MAP
HR

$\begin{array}{llll}0.9 \% \mathrm{NaCl} & 13 & 155 \pm 3 & 315 \pm 11 \\ \text { Verapamil } & 10 & 157 \pm 3 & 337 \pm 5\end{array}$

There were no statistlcally significant differences between the preInfuston values of MAP and HR in the two groups. Long-term hemodyrantc effects on MAP, HR, renal hindquarter and mesenterlc flow and the calculated resistances in the three wascular beds, expressed as percentage changes from the pre-Infusion values are presented in f $1 \mathrm{~g}$ * 5.7 .

A 5-day infusion period of verapanil (10 $\mathrm{mg} / \mathrm{kg} \cdot \mathrm{d})$ reduced MAP signiflcantly $(p<0.05)$ as compared to the control group. During the first infusion day, MAP was reduced by $12+1 \%$ and remalned reduced to a similar degree during the followlng 4 infusion days.

No Influence of verapanil was observed on HR during long-term infusion. Also, no differences in renal, hindquarter and mesenteric flow were observed between the control and verapantl treated groups. 
Renal and hindquarter resistances were reduced almost conknuously durlng the first 3 infusion days. Mesenterlc resistance was reduced during the first infuston day. The resistances in all three vascular beds remalned reduced to a similar degree during the following infusion days. Although in the long-term the Individual resistances were reduced by approxtmately $20 \%$ these effects did not reach a level that was statistically significantly different from the effects in the control group.

\subsubsection{Effect on plasma renin concentration}

The absolute values of MAP, HR and PRC measured on day 0 before the start and after a 4 days infusion period of saline and
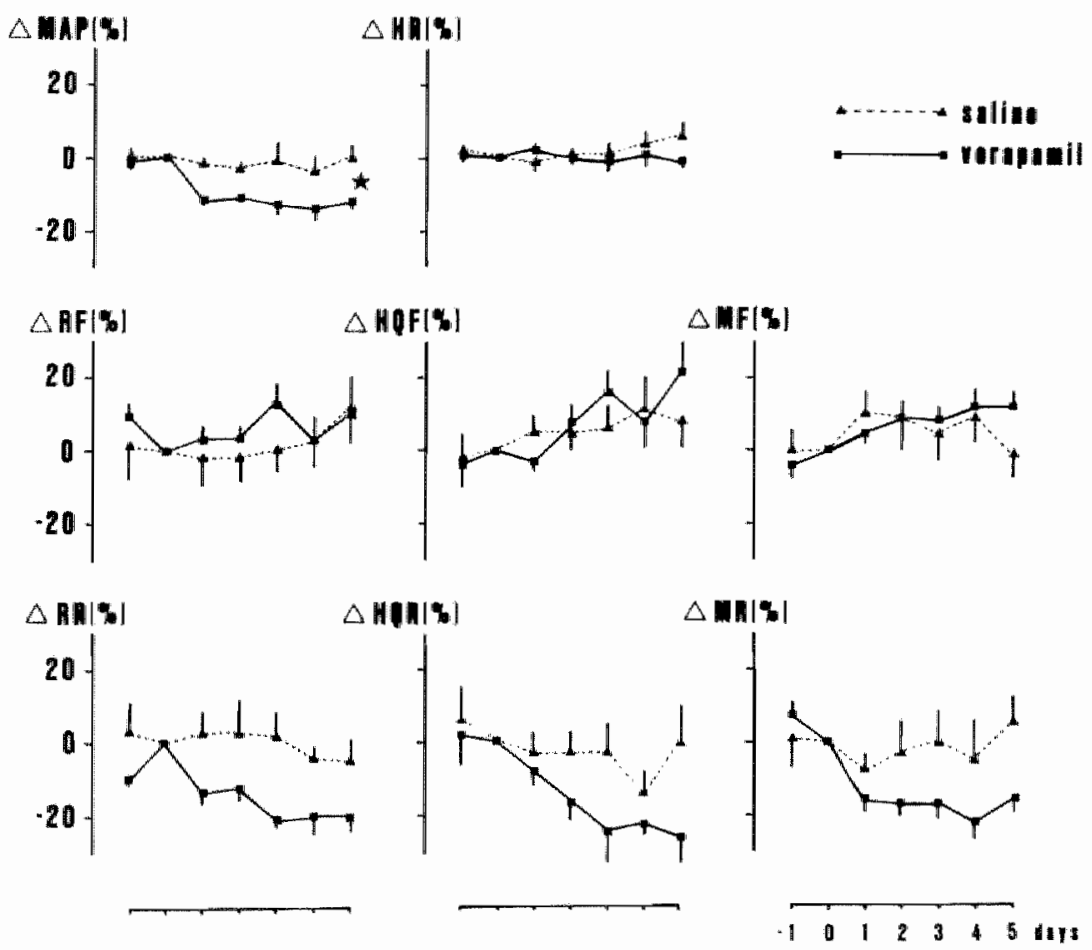

Pig. 5.7: Pencentage changes (mean \pm SEM) in mean arteriat pressume (MAP), heart rate (HR), renai ( $R F$, $R R)$, hindquarter (HQF, HQR and mesenteric IMP, MRl flow and resistance during a $5-d a y$ i.v. infusion of saline $(24 \mu \mathrm{l} / \mathrm{d})$, or $10 \mathrm{mg} / \mathrm{kg} \cdot \mathrm{d}$ verapamit in conscious SHR. OBmotic minipumps were implanted after the second measurement. 
verapanil (10 $\mathrm{mg} / \mathrm{kg} \cdot \mathrm{d})$ are presented in table 5.5 .

No significant differences were abserwed in the pre-infusion values of MAP, HR and PRC in the different experimental groups. Long-

Table 5.5: Blood presaure (MAP, mm Hg), heart rate (HR, bpm) and plasma rentin activity (PRC, ng AI/mh.hr) in the saitine and verapaniz (10 $\mathrm{mg} / \mathrm{kg} \cdot \mathrm{d}$ ) treated group just before (day o) and atter a 4-day infusion period. Data are expressed as mean - SEM. Significanoes are given in comparison to prom infusion values: * $p<0.01$.

\begin{tabular}{|c|c|c|c|c|c|}
\hline & $\mathrm{n}$ & day & MAP & $\mathrm{HR}$ & $\mathrm{PRC}$ \\
\hline $\begin{array}{l}0.9 \% \mathrm{NaCl} \\
(0.1 \mathrm{~m} 1)\end{array}$ & 6 & $\begin{array}{l}0 \\
4\end{array}$ & $\begin{array}{l}176+7 \\
168+7\end{array}$ & $\begin{array}{l}325+7 \\
338+9\end{array}$ & $\begin{array}{l}7.1+0.8 \\
7.5+1.1\end{array}$ \\
\hline $\begin{array}{l}\text { verapam } 11 \\
(10 \mathrm{mg} / \mathrm{kg} \cdot \mathrm{d})\end{array}$ & 11 & $\begin{array}{l}0 \\
4\end{array}$ & $\begin{array}{l}175+3 \\
152+3 * *\end{array}$ & $\begin{array}{l}330+6 \\
328+6\end{array}$ & $\begin{array}{l}7.3+1.1 \\
5.9+0.5\end{array}$ \\
\hline
\end{tabular}

term infuston of verapamil (10 $\mathrm{mg} / \mathrm{kg} \cdot \mathrm{d})$ signiflcantly reduced MAP by about $13 \%$ but did not influence HR. The MAP was significantly different from the control group. PRC was also reduced during long-term treatment although the difference was not signdficant.

\subsection{Discussion}

In this study, investigated the central and reglonal hemodynamle actions of three calctum entry blockers in the conscious, unrestralned SHR. For the central hemodynamic measurenents, rats were chronlcally fnstrumented wh electromagnetic flowprobes and for the reglonal hemodynamics, with mintaturized Doppler flowprobes. In previous chapters discussed in this thesis, we were able to show the usefulness of these models to study hemodynamic effects. The major advantage of these models is that they allow the continuous characterlzation of hemodynamic effects of anthypertenstve drugs in undis- 
turbed, unanesthetized hypertensive animals.

The three calcium entry blockers used in thls study caused a capld and profound fall in blood pressure, the magnitude of which depended upon the dose injected. Moreover, we showed that the fall in blood pressure was associated with a reduction of total peripheral reslatance. Previous studles indicated a simllar hemodynamic pattern for varlous calcium entry blockers in hypertensive patients (Kiowskl et a1, 1983; Lehmann et a1, 1983), normotensive dogs (Gross et a1, 1979), cats (Hof et al, 1982) and rats (Flaim and Zelis, 1982).

In thls study, we have pald special attention to the reglonal vascular effects underlying the fall in total peripheral resistance. Thus far, the fefects of calclum entry blockers on reglonal blood flow distribution were mostly studied in normotenslve rats and cats (see chapter 1) using the microsphere method. These studies show that different types of calclum entry blockers preferentially dilatate skeletal muscle, coronary and cerebral vascular beds. In other vascular beds (kidney, resentery and skin), the effects of calcium entry blockers were more divergent. In our reglonal hemodynamic study, we observed a reduction in hindquarter but no change in renal and mesenterlc reslstance after verapanil 1 and both dihydropyridines, PY 108-068 and nifedipline.

A reduction in muscular vascular resistance was obserwed by Reed and Tuma (1986) for nifediptne and Hof (1983) for PY 108-068 and nicardipine in anesthetized rats. Hof also observed a reduction in skelletal muscle vascular resistance for $P Y 108-068$ and nifedipine in anesthetzed cats. In another study, nisoldipine was found to have a vasodlator effect in skeletal muscle in consclous rats (Drexler et a1, 1985). Kanda and Flaim (1984) observed in consclous rats only small reductions in muscular resistance. Flatm and Zelis (1982) showed that diltiagem reduces reststance in the skeletal muscle vascular bed. Whth respect to the hindquarter vascular bed, all these observations are in accordance with the present regional hemodynanic effects (However, a decrease in nuscle vascular resistance together wh no effect on renal and mesenteric resistance within one study wot abserved in these previously published studies). Flalm and Zelis (1982) found no effect on renal but a reduction in mesenteric resistance. Kanda and 
Flaim (1984) observed a resistance reduction in both the kidney and the mesentery and Drexler et al (1985) a reduction in renal resistance and no effect on mesenteric resistance. Even Barron et al (1983) who used the same method that we used in the present study found next to the profound reduction in hindquarter resistance also a decrease in mesenteric resistance after nitrendipine, nisoldipine and veraparili in normotensive rats. Furthermore, Bolt and Saxena (1984 b) abserved an almost general vasodilation for the calclum entry blocker felodipline in hypertensive rabbits. In the present study in hypertensive rats we did, however, only observe dilatation in the skeletal muscle.

The question arises whether these observations tadicate that calcium entry blockers are vasodilators with selectlvity for certain vascular beds, more spectflcally for the muscular bed. Our results in the sino-aortic denervated SHR point to a different expldination. Calcium entry blockers loose their predominant muscular vasodilating effect after baroreflex denerwation. In fact, in the denervated SHR the degree of vasodilatation was comparable for all three vascular beds. The blood pressure lowering potency of the calclum entry blockers was increased 10-fold. In denervated consclous normatensive rats with verapamil, nitrendipine and nisoldiplne (Barron et a1, 1983) there was also a 10-fold increase in potency for these drugs. These results suggest that in intact animals the fall in blood pressure triggers a baroreceptor reflex medlated increase in symathetic nerve activity which counteracts the direct vasodilatation otherwise observed in the renal and mesenterlc vascular beds.

other studies support the possibility of an acute actutition of baroreflex mechanisms. Thus, several authors observed an early increase in plasma noradrenaline concentrations in hypertensive pat ents, following calclum entry blockers (Klowski et al, 1983; Murphy et a1, 1982).

In chapter 3 we have shown that a baroreflex actuation induced by an unilateral carotid occlusion in conscious SHR increases renal, hindquarter and mesentertc resistance. Also the Influence of the baroreflex on the effects of hydralazine (see chapter 4) on renal, hindquarter and mesenteric resistance was similar in all three vascular beds. Baroreceptor denervation did not affect the reglonal hemo- 
dynamlc response to this agent. These results indlcate that preferental musular wasodiatation of CEBs can not be explained on the basis of a different degree of sympathetic innervation of the vascular beds. This tralies a posibly selective interference with the syapathetic influence on skeletal muscle vascular beds by CEBs. In our hemodynamic studies, drugs were administered $\mathbb{1} . v .$, so the site of action of the calclum entry blockers can be anywhere in the baroreflex pathway.

Heesch et al (1983) observed direct effects of calcium entry blockers on baroreceptor discharge $1 \mathrm{n}$ dogs. They presented evidence that iffedipine increased whereas verapamil decreased baroreceptor diacharge. In that study, nifediplne and verapamil also had opposite effects on the renal sympathetic outflow. It is unlikely that such a direct effect of calclum entry blockers on baroreceptors explalns the blockade of the sympathetic influence on the skeletal muscle vascular bed because in the present study, no differences beween nifedipine and verapamil were observed with regard to reglonal vascular beds. Furthermore, Kunze et al (1986) did not find direct effects of calcium entry blockers on baroreceptors in the range in which effects are expected to be selective for calclum entry blockade. Only in the range of high concentrations in which non-selective effects are expected did they observe a simllarly depressed afferent reflex for nifedipine and verapamil.

A recent report from Higuchi et al (1985) suggests that $\mathbb{1}$ n rats, calcium lons play an important role in the integral function of neurons in the brain stem, particularly in the nucleus tractus solltarif. They showed that verapamil, dilthazem and nifedipine administered In the braln stem produce excltation of the nucleus tractus solltaril neurons resulting in a withdrawal of sympathetic outflow. This could be a possible explanation for the observed reglonal hemodynamic effects of calctum entry blockers in the present study. In this hypothesis calclum entry blockers may block the sympathetic influence on the skeletal muscle possibly by a direct effect on the nucleus tractus solitaril without Interfering the sympathetic outflow to the kidney and mesentery. In an unpublished study, we observed such a differentiated sympathetic outflow by electrical stimulation of the median raphe nucleus which is also involved in the baroreflex pathway. 
It has been proposed that vasoconstriction mediated by alpha adrenoceptors is dependent on the influx of extracellular calcium

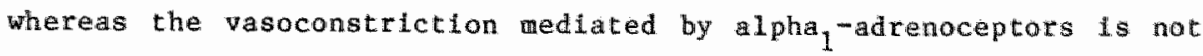
(Van Meel et al, 1983; Saeed et al, 1983; Van Zweten et al, 1983). The non-selective catecholamines stimulate both alpha ${ }_{1}$ and alpha ${ }_{2}$ adrenoceptors at postsynaptic sites. Assuring that vascular tone is malntained by stimulation of both receptor subtypes the constrictor effect of alpha ${ }_{2}$-adrenoceptor stimulation is dimintshed in the presence of a calclum entry blocker. Then, differences in alpha $/$ alpha $_{2}$ ratio between the hindquarter and the other two renal and mesentertic vascular beds could also explain the selectlve blockade of the sympathetic influence on skeletal muscle vasculature as was seen in the present study. However, studies performed with perfused dog hind 1 imbs showed that especially alpha,-adrenoceptors are sympathetically innervated whereas alpha ${ }_{2}$-adrenoceptors are located extrafunctionally (Langer and Shepperson, 1982). These studies suggest that a noradrenergic nerve stinulation of the skeletal nuscle vascular bed will be relatively insensitive to inhlbition by CEBs which makes the explanation based on the alpha 1 /alpha 2 ratio very un1lkely.

The present reglonal hemodynamic studtes show that calclum entry blockers are not preferentially muscular vasodilators but also reduce renal and mesenteric resistance in baroreceptor denervated animals. Furthermore, it is $11 \mathrm{kely}$ that they also dilate other vascular beds to a considerable extent because the reduction in total peripheral resistance seen in the central hemodynamic studies was greater than the fall in resistance in the muscular bed. Possibly, coronary and cerebral resistances are also reduced although the methods we used do not allow quantitation of these resistances.

The baroreflex medlated tncrease in sympathetic activity explains some of the acute changes observed in central hemodynamic varlables after calctum entry blockers. The early rise in heart rate and cardiac output following nifediptne and PY 108-068 were probably due to indirect mervous reflex mechantsms rather than a direct cardiac action of these drugs. A simflar conclusion was reached by Nakaya et aI (1.983) in a recent study in which they investigated the cardiac responses to verapamil, diltlazem and nifediplne in chronically $\mathbb{1 n}^{-}$ 
trumented conscious dogs. The drect cardlac action of calcium antagonists may even lead to negative inotroplc (nifediplne: Férez et al, 1982) or negatuve chronotrople and lnotroplc (verapand and dilt lazem: Pérez et al, 1982; Nakaya et al, 1983) effects. The direct cardiac effects of verapandi may explain why lncreases in heart rate and cardiac output were almost completely absent in our study, following this drug in contrast to nifediplne or PY 108-068. In addition, the inhibltory effects of verapamil on carotid sinus baroreflex, as opposed to the excltatory effects of nitedlpine may be involved in the differential effects of these agents on cardiac hemodynamic variables (Heesch et a1, 1983).

In short-term studies, the baroreceptor reflex in particular may atrongly influence the hemodynamlc effects of an antihypertensive agent. On the long-tern the influence of baroreceptor reflex mechanisms may be less dominant, because of adaptation of these mechanlsms to the prevalling level of blood pressure. During long-term treatment, verapamil reduced renal hindquarter and mesenteric resistance. However, the effects on reglonal resistances during long-term verapanil treatment were not significantly different from the control values. This in contrast to the rapid signiflcant reduction in blood pressure to a new steady-state level. Further studies will be necessary to find out whether higher infusion doses of verapamil administered to SHR will lead to a significant vasodilation in all three vascular beds.

If we assume that verapam 1 at higher doses $\mathbb{1 n d u c e s}$ a general vasodilatation during long-term treatment, this long-term reglonal pattern is similar to that observed in sinomartic baroreceptor denervated antmal in the acute studles. These results then suggest a rapid baroreceptor reflex resetting during long term verapamil treatment. Mostly, baroreflex activity is correlated to the changes in heart rate and cardiac output. This is not posstble in the case of verapamil because that drug directly interferes with the baroreflex pathway (Pérez et a1, 1982; Heesch et a1, 1983; Nakaya et a1, 1983) reducing the baroreflex mediated effects on the heart. Thus, it is not clear whether the general reduction in vascular resistance ls a consequence of a rapid baroreceptor resetting in the long-term studies *

In the long-term, the Influences of baroreflex mechanisms may 
be less doninant because of adaptation of this mechanlsm to the prevalling level of blood pressure. Then, possibly the renin-anglotensinaldosteron system could influence the reglonal hemodynanlcs of calcium entry blockers. Therefore, we investigated in the last part of the study the influence of a long-term verapanil treatment on plasma renin activity in conscious SHR.

Our results showed a slight but not significant reduction in plasma renin concentration after a 4-day verapamil infusion. In contrast to the present findings, Dietz et al (1983) reported an increase in renin secretion during intrarenal infusion of alfedipine in anesthetized dogs. Similar results were observed by Imagawa et al (1986) and abe et al (1983) in anesthetized dogs using intrarenal nifediplne infusions. Only at hypotensive doses of nlfedipine, increases in rentn secretion were observed by Dietz et al (1983). Furthermore, he did not observe an increase in rentn secretion when the kidney was denervated. This in contrast to Imagawa et al (1986) who abserved a stimulatory effect of nifedipine on renin release also at non-hypotenstve doses. The results of Dietz et al suggest an involvenent of the baroreflex mediated sympathetic activation on the kidney increasing renin secretion. The results of Imagawa et al (1986) suggest, however, a direct effect of calcium entry blockers on fuxtaglomerular cells. Kotchen et al (1974) and Watkins et al (1976) have suggested that enhancing calcium Influx into the juxtaglomerular cells inhibits the renin release from the Juxtaglomerular cells. Taklng this into consideration, the lack of an enhancement of renln secretion by verapamil during long-term treatment is possiblly a consequence of blockade of sympathetic activation by a direct effect of verapamil on the juxtaglomerular cells, such an explanation is posslble tf the baroreflex is still not reset after 4 days of infuston, thds is still unclear. Another possibility could be that the plasma verapamil concentration during Intravenous infusion is too low in the present study for a pronounced direct effect on the Juxtaglonerular cells as compared to the intrarenal alfedipine infusion.

In sumary, the central and regional hemodynamlc actions of the calcium entry blockers verapamil, nifediplne and PY 108-068 were evaluated in chronically instrumented, conscious SHR. All three agents 
caused a dose-dependent fall in blood pressure and total peripheral resistance. The fall in blood presaure triggered a baroreflex mediated rise in heart rate and cardiac output which was probably counteracted by direct cardiac effects in the case of verapamil. In intact animals, the acute fall in total peripheral resistance was related primarily to a decrease in vascular resistance of the muscular bed. However, the calclum entry blockers canoot be regarded as selective dilators of this vascular bed, since in baroreflex denervated SHR and during long-term treatment in intact SHR, the degree of vasodilatation was stmilar in all three vascular beds studies. Also no effect on PRC was observed during chronic verapanil treatment. 
CHAPTER 6

\section{HEMODYMAMIC EFFECTS OF THE BETA-ADRENOCEPTOR BLOCKERS PROPRANOLOL AND TERTATOLOL}

IN CONSCIOUS SPONTANEOUSLY HYPERTENSIVE RATS

\subsection{Introduction}

Beta-adrenoceptor blockers are used in the therapy of a wide varlety of cardiovascular diseases, including hypertension. The acute hemodynamic actions of most beta-adrenoceptor blockers in hypertenstve patients or antmals consist of a fall in cardiac output, whereas a rise in total perlpheral resistance prevents an early fal1 1 n blood pressure (U1rych et al, 1968; SmLts et al, 1982; Cofler et al, 1984; reviews: Fitzgerald, 1984; Wan Baak et a1, 1985).

During the last few years, attempts have been made to develop beta-adrenoceptor blockers with ancillary vasodilator properties, e.g. prizidilol (Taylor et al, 1981) and carvedilol (Eggertsen et al, 1984). Furthermore, beta-blackers with a more selectlve reglonal hemodynamic profile of action have been described. In this respect, the development of beta-blockers that maintain normal renal perfustion have received special attention. Such an action has been clatimed for the beta-blockers nadolol (O'Connor et a1, 1982; Danesh et al, 1984) and tertatolol (Lantz et al, 1984).

The first purpose of the present study was to lnvestlgate the effect of the classical beta-blocker propranolol and tertatolol (Servier compound 2395) a potent, long-acting, non-selective beta-blocktng agent without sympathomimetic activity (Lauble et al, 1973), on central and reglonal hemodynamics in consclous SHR.

Microsphere studles in several animal models indicate a generalized acute vasoconstriction following propranolol (Nies et al, 1973; Van Boom and Saxena, 1983; Hatzinikolaou et al, 1983).

In prevlous studles, it was shown that the early rise in total peripheral resistance is most 11 kely caused by a baroreflex medlated 
rise in syapathetlc nerwe activity (Struyker Boudier et al, 1979).

The second purpose of the present study was to further investigate the role of baroreceptor reflex activation in the early peripheral vasoconstriction following beta-adrenoceptor blockade with the beta-blockers propranolol and tertatollol. Therefore, we compared the reglonal hemodynamic effects determined with the Doppler technique af both beta-blockers in intact and slno-aortic baroreceptor denervated consclous SHR.

The third aspect on which this study focusses, is the effect of both beta blockers on renal hemodynamics and excretory function. It has been reported that renal plasma flow and/or glomerular flltration rate (GFR) are reduced during administration of beta-blockers (Wilklnson, 1982, Weber et al, 1984). However, nadolol has been reported to spare or even increases renal blood flow (Britton et al, 1981 and Danesh et a1, 1981) without affecting GFR. Lauble et al (1986) showed that tertatolol and the classical beta-blocker propranolol have different effects on renal hemodynamics and function in conscious dogs. They found that, in contrast to propranolol, tertatolol increases GFR and urtne and sodium excretion. In their study, no effect of tertato101 and propranolo1 on renal plasma flow was observed. Lantz et al (1984) observed that tertatolol given arally increases both renal plasma flow and GFR in hypertensive patients with or whout chronic renal fallure. These experiments suggest that tertatolol, like nado101, preserves renal perfusion possibly by an additional pharmacodynamic action that $\mathrm{Ls}$ independent of beta-adrenoceptor blockade.

Baroreflex desactiwation most 11 kely causes the early increase in peripheral resistance after beta blockers, but during long-term treatment baroreflex resetting may occur and the Influence of the renin-aldosteron system may be more dominant. Therefore as a fourth aspect of this study we Investigated the long-term effects of both beta blockers on reglonal hemodynamics and plasma renin concentration in consclous SHR. 
6.2 Experimenta1 protocol

6.2.1 Animals

Male SHR, weighing $250-350 \mathrm{~g}$, were used in the studies described in this chapter. More details are glven in section 2*1.

\subsubsection{Central hemodynamic studies}

Methods for fmplantation of flow probes and catheters for central hemodynanic studies were described in chapter 2. For measurement of blood pressure and cardiac output, rats were placed in normal experimental cages $(20 \times 20 \times 30 \mathrm{~cm})$. After atabilization perlod of 1 hr, an injection of $0.1 \mathrm{ml}$ saline $(n=10)$ or $0.5 \mathrm{mg} / \mathrm{kg}$ tertatolol $(\mathrm{n}=6)$ was given $\mathrm{i} . \mathrm{v}$. Henodynanics were monitared continuously during the first of hr after the infection. Furthermore, measurements were made 20 hr after the injection. Cardiac output was normalized for body weight and expressed as $\mathrm{ml} / \mathrm{min} .100 \mathrm{~g}$ bw. This value wil be referred to as cardiac index (CI). From MAP and CI, total perlpheral reststance was calculated (TPRI $=$ MAP/CI; mm Hg.min.100 g bw/ml). Furthernore, SVI was calculated from $C I$ and $H R(S W I=C I / H R ; m 1 / 100 \mathrm{~g} \mathrm{bw})$.

\subsubsection{Regional hemodyramic studies}

Two groups of antmals were used for this expertment. In one group, the sino-aortic bacoreceptors were denervated and in the other group the sinoarotic baroreflex was left intact. On the morning of the experimental day, the implanted measuring devices in the conscious anlmals were connected to their respective equfpment. Arterial blood pressure was measured from the Intra-aortic catheter using a minlature strain gauge transducer (model CP-0L; Century Technology Company, Inglewood, Ca, USA). Reglonal blood flows were measured as $\mathrm{KHz}$ Doppler shift using a 4-chamel $20-\mathrm{MHz}$ directional pulsed Doppler system (Bioengineering Department, Unlversity of Iowa, lowa City, IA, USA). Zero blood flow was deternined electronlcally. Mean pressure and flow signals were obtained by electronic low-pass flltering * Reglonal resistance changes were calculated from pressure and flow changes according to procedures prevlously descrtbed in detail (Smits and Struyker Boudier, 1984). 
Animals were given at least $1 \mathrm{hr}$ to get used to the experimental conditions. Pre-infection values were obtained as the average of 4 readings at 5-min intervals in the last 20 min before an injection. Drugg were injected intravenously in $0.1 \mathrm{ml} 0.9 \% \mathrm{MaCl}$ after which the catheter was flushed slowly wh $0.3 \mathrm{ml} 0.9 \% \mathrm{NaCl}$. Control injections consisted of $0.1 \mathrm{ml} 0.9 \% \mathrm{NaCl}$ followed by slow infusion of $0.3 \mathrm{ml} 0.9 \%$ vacl. Injections of vehicle or drug solutions were given in random order wh at least 2 days between finfections in the same animal. Hemodynamic variables were recorded continuously for at least $4 \mathrm{hr}$ following injection. Effects were measured as the difference from the pre-infection value.

\subsubsection{Renal hemodynamlc and excretory function studies}

In this study, 4 experlmental SHR groups were used recelving sallne $(0.1 \mathrm{ml}), 5 \mathrm{mg} / \mathrm{kg}$ propranalol, $0.1 \mathrm{mg} / \mathrm{kg}$ or $0.5 \mathrm{mg} / \mathrm{kg}$ tertato101 respectively. GFR and ERPF were measured as plasma clearances of respectively [ $\left.{ }^{51} \mathrm{Cr}\right]$ EDTA and $\left[{ }^{125}\right.$ I]PAH in consclous SHR as described in paragraph 2.8 "Method B". Blood and urine samples were collected $1 / 2 \mathrm{hr}$ before ( 1 sample/15 min) and $3 \mathrm{hr}$ after ( 1 sample/30 min) the bolus infections of the respective drugs. GFR (ml/min.g kw) and ERPF $(\mathrm{ml} / \mathrm{min} \cdot \mathrm{g} \mathrm{kw})$ were calculated from urine and plasma concentrations of $\left[^{51} \mathrm{Cr}\right]$ EDTA and [ $\left.{ }^{125} \mathrm{I}\right] \mathrm{PAH}$. Filtration fraction (FF) was calculated as GFR/ERPF. The urine production $(V)$ was continously and directly determined via bladder catheter and expressed as $\mu \mathrm{l} / \mathrm{min} \cdot \mathrm{g} \mathrm{kw}$.

\subsubsection{Long-term regional hemodynamic studles}

The same experimental protocol was performed to determine Long-term reglonal hemodynamics as described in chapter 5.2.3.1. Reglonal hemodynainics were measured every day (during ca. $1.5 \mathrm{hr}$ ) one day before to 5 days after the start of the infusion of $5 \mathrm{mg} / \mathrm{kg} \cdot \mathrm{d}$ propranolol, $0.5 \mathrm{mg} / \mathrm{kg} \cdot \mathrm{d}$ tertatolol or saline using Alzet ${ }^{\text {TM minipumps. }}$ The effects are expressed as percentage change (mean \pm SEM) from pre-infusion values measured on day 0 .

\subsubsection{Long-term plasma renin concentration studies}

The plasua renin concentration studles were performed fol- 
Lowing the same experimental protocol as descirbed in chapter 5.2 .3 .2 * Chronic infusion of sallme, $5 \mathrm{mg} / \mathrm{kg} \cdot \mathrm{d}$ propranolol or $0.5 \mathrm{mg} / \mathrm{kg} \cdot \mathrm{d}$ tertatolol were performed. using Alzet TM minipumps. The effects of MAP (mm Hg), HR (bpr) and PRC (ng AT/ml.hr) were expressed as means I SRM.

\subsection{Results}

\subsubsection{Effects on central hemodynamics}

In this study, the effects of saline and tertatolol on central hemodynamics were determined. Baseline values for the different experimental groups used in the central hemodynamic studies are summarized in table 6.1 .

Toble 6.1: Absolute values (t SEM) of centmal hemodynamic variables before drug administration in the different experimental groups. Units:" mean arterial pressure (MAP), man Hg, candiac index (CI), mL/min.100 g bw; total pemipheral resistance index (TPRI), $m \mathrm{mg} \cdot \mathrm{Hin} .100 \mathrm{~g} \mathrm{bw} / \mathrm{ml}$; heart rate (HR), bpm; stroke volume index (SVI), Hl/100 g bw.
$0.9 \% \mathrm{NaCl} \quad(\mathrm{n}=10)$
Tertatolol $(n=6)$
$0.1 \mathrm{ml}$
$0.5 \mathrm{mg} / \mathrm{kg}$

\begin{tabular}{lcc}
\hline MAP & $139 \pm 3$ & $150+5$ \\
HR & $395 \pm 14$ & $365+14$ \\
CI & $31+3$ & $34+3$ \\
TPRI & $4.8+0.4$ & $4.6 \pm 0.4$ \\
SVI & $79 \pm 7$ & $91+6$ \\
\hline
\end{tabular}

There were no statistically signiflcant differences between the preinjection values. 


\section{$\triangle$ MAPIDHal}

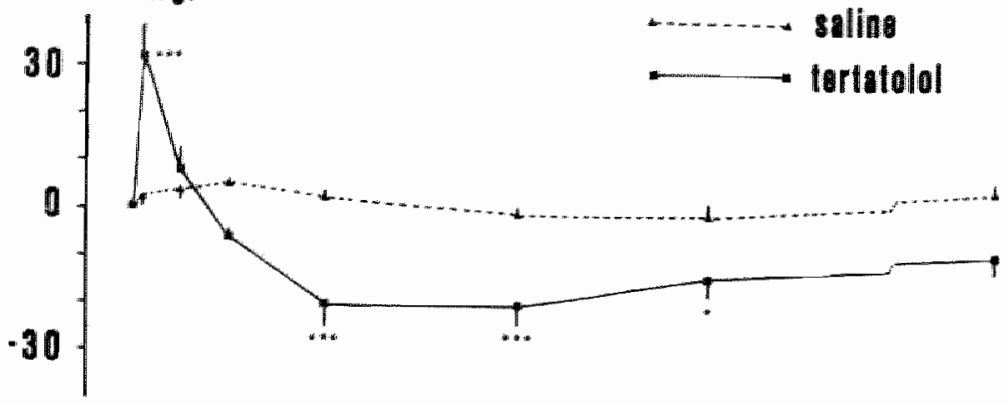

$\triangle$ Cllml/min.ulogl

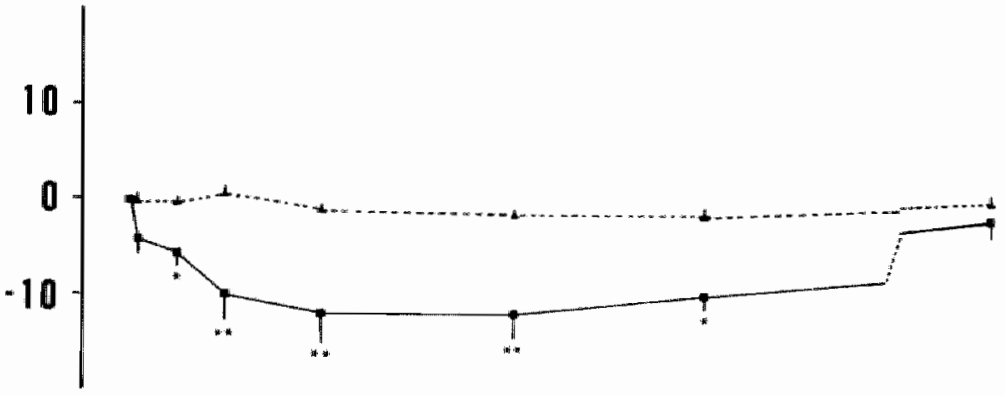

$\triangle$ TPAIImaHg.min100.0/mll
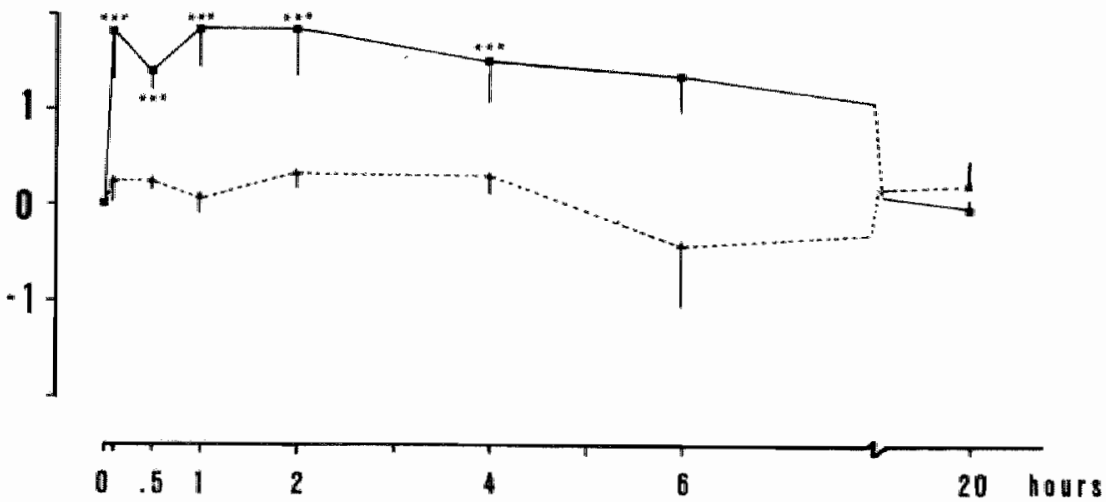

Fïg. 6.1: Changes (mean + SEM) in mean artemial preseure (MAP; man Hg), cardiac index (CI; ml/min.100 $\mathrm{g}$ bw) and total pemipheral reaistance index (TPRI; mm $\mathrm{Hg} \cdot \mathrm{min} .100 \mathrm{~g} \cdot \mathrm{ml}^{-1}$ ) following aaline $(24 \mathrm{\mu l} / \mathrm{d})$ or $0.5 \mathrm{mg} / \mathrm{kg}$ tertatolol in conscious SHR $(n=6)$. 
Effect of saline and $0.5 \mathrm{mg} / \mathrm{kg}$ tertatolol on MAP, CI and TPRI during 20 hr post-injection are presented in $\mathrm{fig} .6 .1$ and on HR and SVI in fig. 6.2. Injection of saline caused only slight wariations in MAP, CI and TPRI during the measuring periods. After tertatolol, two distinct phases in the effect on MAP could be recognlzed. During the first $1 / 2 \mathrm{hr}$, it significantly increased from baseline value by maximally $32+7 \mathrm{~mm} \mathrm{Hg}$ ( $\mathrm{p}(0.001)$ After that period, MAP decreased and was signiflcantly below control values durlng 2 to 6 hr after the injection (maximal reduction $20+4 \mathrm{~mm}$ Hg; $p<0.001$ ). Twenty hr after
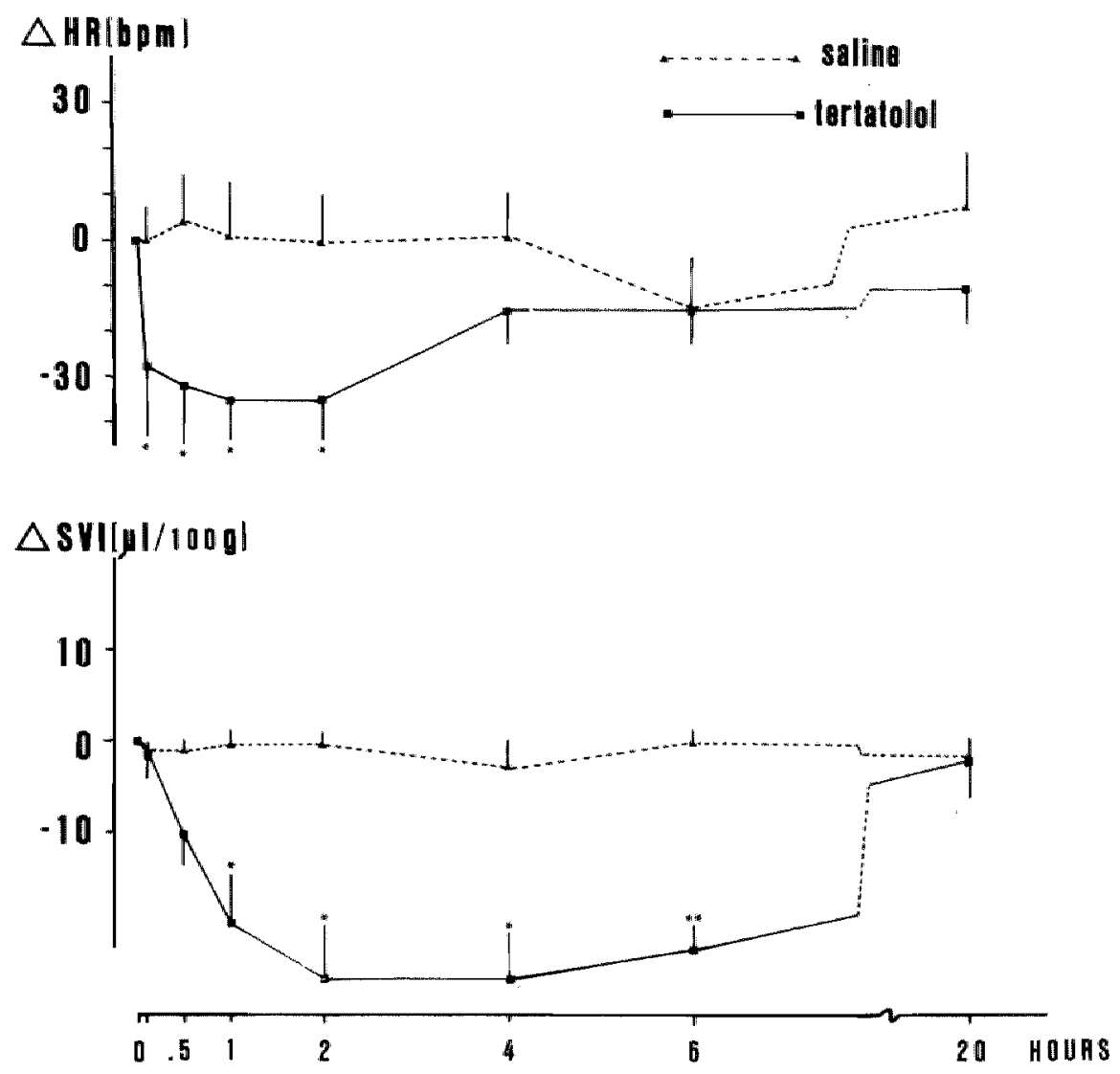

Fig. 6.2: Changes (mean $+S E M)$ in heart rate (HR; bpm) and stroke volume index $\overline{(S V I ;}$ mL/100 $g$ bw) following galine or 0.5 $\mathrm{mg} / \mathrm{kg}$ tertatolol in conseious $S H R(n=6)$. 
tertatolol injection, MAP was still reduced but no longer significant1y different from the control values. Tertatolol immediately reduced CI This vartable was significantly different from control values between $1 / 2$ and 6 hr post-injection, with a maximal reduction of $12+2$ mL/min. $100 \mathrm{~g}$ bw (p<0.01) obserwed between 1 to $4 \mathrm{hr}$ after the bolus injection.

HR was inmediately and significantly reduced ( $p<0.05)$ after tertatolol to nearly the same extent from $1 / 2$ to $2 \mathrm{hr}$ (maximal reductlon: $-35+9$ bpal). Four hr post-injection, HR returned to control values. SVI also decreased immediately after the bolus injection of tertatolol. One hour after injection SVI was significantly reduced with a maximum of $-28+5 \mu 1 / 100 \mathrm{~g} ; p<0.05)$. It returned to control values within 20 thr post-injection.

Injectlons of $0.5 \mathrm{mg} / \mathrm{kg}$ tertatolol caused an immediate steep increase in TPRI. It was significantly different from control values $(p<0.001)$ between $1 / 2$ and 4 hr post-injection (maximal increase: $1.8+0.4 \mathrm{~mm} \mathrm{Hg} \cdot \mathrm{min} \cdot 100 \mathrm{~g}$ bw/ml). Twenty hr post-infection, no statistically algnificant differences in MAP, CI and TPRI were observed between values of the drug treated and control groups.

\subsubsection{Effect on regional hemodynamics}

\subsubsection{Intact animals}

Table 6.2 summarizes the pre-injection values in the different experimental groups and figures 6.3-6.5 summarlze the regional hemodynamic effects of injections of $0.9 \% \mathrm{NaCl}(\mathrm{n}=7), 5 \mathrm{mg} / \mathrm{kg}$ propranolol $(n=9)$ and $0.5 \mathrm{mg} / \mathrm{kg}$ tertatolol $(\mathrm{n}=7)$, measured at $15-30 \mathrm{~m} / \mathrm{n}$ and $3-4 \mathrm{hr}$ post-injection. Both beta-blockers caused an immediate fall in HR, which was maximal 15-30 min after injection. MAP, on the other hand, changed in a blphasic manner. During the first 15-30 min after the beta-blockers, it increased signiflcantly, whereas it fell below control values within $3-4$ hr after injection.

propranolol caused a significant early (15-30 min) increase in the resistances of the renal, mesenteric and hindquarter vascular beds. This increase was parallelled by a fall in blood flow through all tissues, although a statistically significant level was attained only for renal blood flow. 
Table 6.2: Ere-injection values (mean + SEM of MAP(mi Hg) and HR (bpm) in intact and sino-aonte baroreceptor denerpated (SAD) SHR. "p<0.05: significantly different from intow animals. $n=$ number of test aninals.

\begin{tabular}{llll}
\hline Experinental group & $\mathrm{n}$ & MAP & HR \\
\hline NaCl $(0.9 \%)$ & & & \\
$\quad$ Intact & 7 & $147+8$ & $303+9$ \\
SAD & 10 & $143 \pm 10$ & $354 \pm 12 *$ \\
$\begin{array}{l}\text { Propranolol }(5 \mathrm{mg} / \mathrm{kg}) \\
\quad \text { Intact }\end{array}$ & 9 & $140+6$ & $304+5$ \\
SAD & 10 & $154 \pm 7$ & $374 \pm 8 *$ \\
Tertatolo1 $(0.5 \mathrm{mg} / \mathrm{kg})$ & 7 & $141+5$ & $301+8$ \\
$\quad$ Intact & 10 & $136 \pm 5$ & $374 \pm 11 *$ \\
SAD & & & \\
\hline
\end{tabular}

A different pattern of reglonal hemodynamic changes was obtalned after tertatolol. This agent caused a significant early increase in HQR only. Renal resistance gradually decreased to reach a statistlcally signiffcant reduction $3-4$ hr after injection. Renal blood flow remalned stable and even tended to increase although not significantiy.

\section{$6 \cdot 3 \cdot 2.2$ SAD animals}

The effects of $0.9 \% \mathrm{NaCl} \quad(\mathrm{n}=10), 5 \mathrm{mg} / \mathrm{kg}$ propranolol $(\mathrm{n}=10)$ and $0.5 \mathrm{mg} / \mathrm{kg}$ tertatolol $(\mathrm{n}=10)$ in $S A D$ animals are summarized in flgs. 6.3-6.5. Table 6.2 show's the pre-injection values of MAP and HR in Intact and SAD animals. The data show that SAD does not lead to a further elevation in blood pressure in consclous SHR, although we noted that blood pressure was much more lablle in these animals. On the other hand, HR was signiflcantly higher in the SAD animals.

Both propranolol and tertatolol caused a larger and longer lasting faII in the HR in SAD than in intact SHR (fIg. 6.3). Furthermore, MAP decreased almost immedlately after the beta-blocker administration in SAD animals. It was already significantly lowered at $15-30$ min. After 3-4 hr, the reduction in MAP did no longer differ signiflcantly from that in intact andmals. 
In SAD animals, propranolol and tertatolol no longer caused a signiflcant early increase in resigtance in the mesenterlc and hindquarter vascular beds. The respectlve blood flows decreased signiflcantly 15-30 min after the administration of propranolol and tertato10l. In the hindquarter vascular bed, the flow reduction persisted unt1 3-4 hr after infection of both beta-blackers.

In the renal vascular bed, the early increase in resistance which occurred only wth propranolol in intact animals, was no longer abserved in SAD anlmals. Renal reslstance even decreased with both

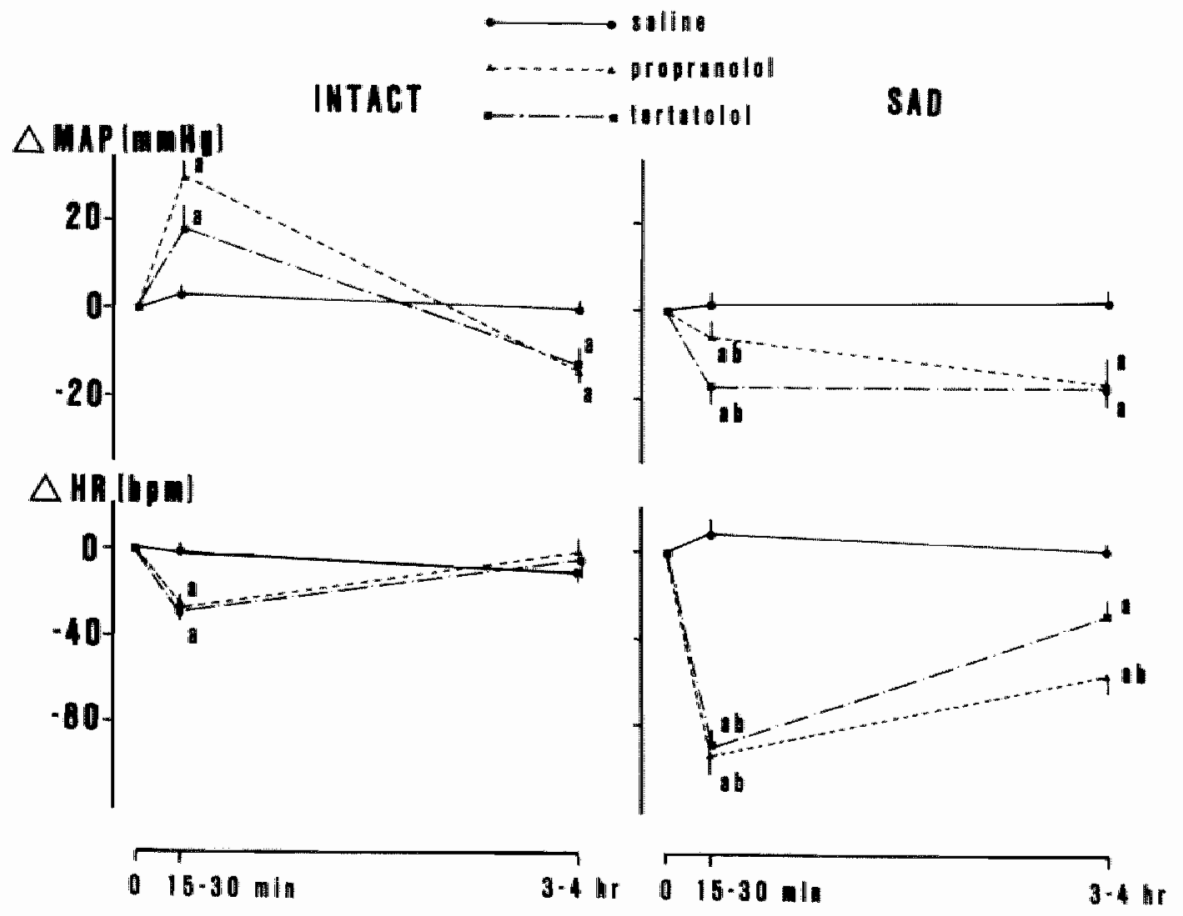

Fig. 6.3: Effects of aaline, $5 \mathrm{mg} / \mathrm{kg}$ propranolol and $0.5 \mathrm{mg} / \mathrm{kg}$ tertatolol on mean arterial pressure (MAP: $\mathrm{mm} \mathrm{Hg}$ ) and heart rate (HR: bpm) in intact and sino-aortic baroreceptor denervated (SAD) conscious SHR.

$a_{\text {significantly }(p<0.05)}$ different from corresponding saline group

oignificantly $(p<0.05)$ different from corresponding intact rats. 
agents at $15-30$ min and $3-4$ hr after administration.

6.3.3 Effects on renal hemodynamics and excretory function Effects on renal plasma flow (EPRF), glonerulat flltration rate (GFR), filtration fraction (FF) and urine production (V) in the 4

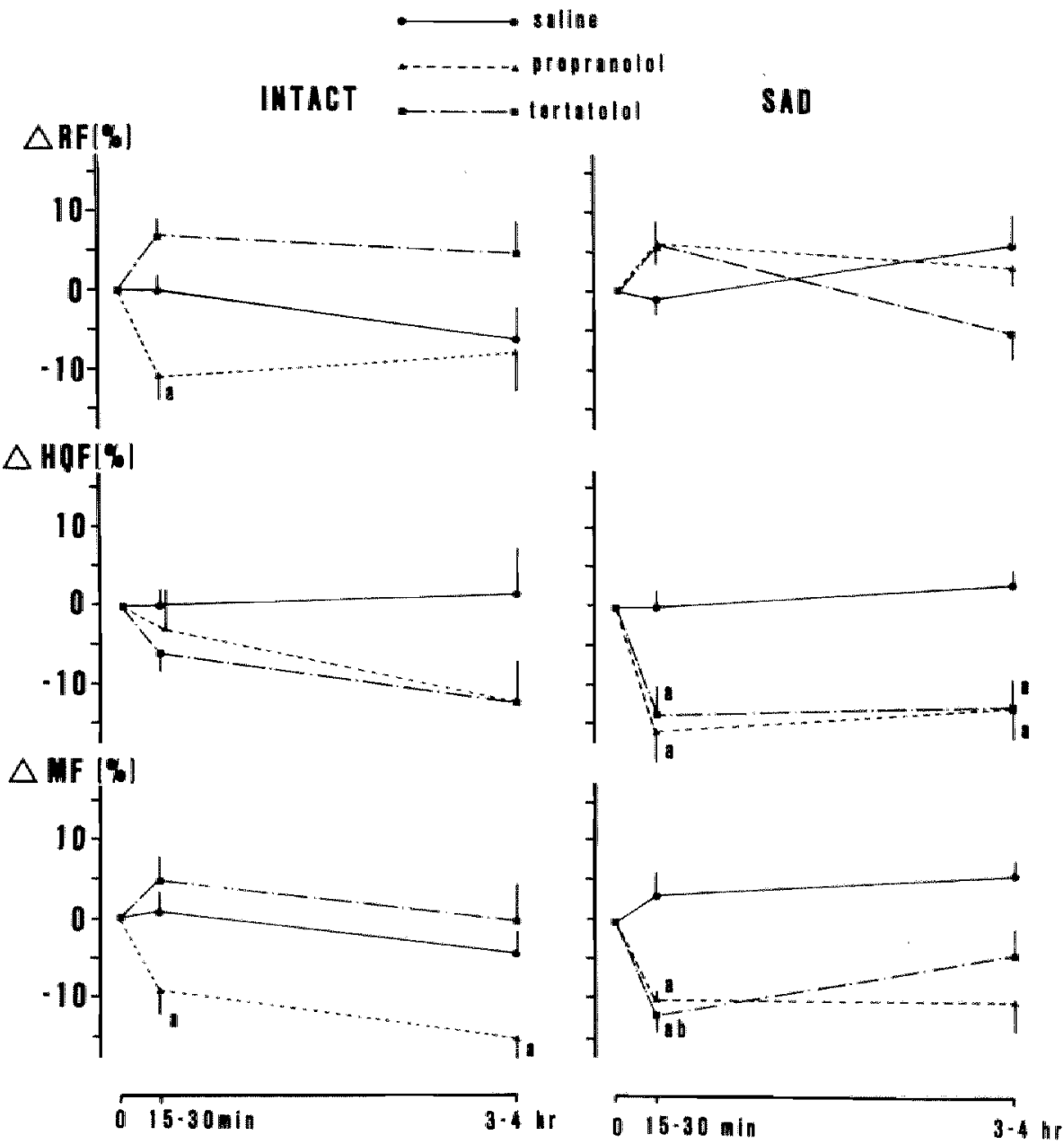

Fig. 6.4: Percentage change of menat blood flow (RE), hindquarter flow (HQF) and mesenteric flow (MF) after $i . v$. Baline, $5 \mathrm{mg} / \mathrm{kg}$ propranolal or $0.5 \mathrm{mg} / \mathrm{kg}$ tertatolot administration in intact and aino-aortic baroreceptor denervated (SAD) conscioue SHR. 
dufferent experimental groups measured -15 to 0 min before and 30 to $60 \mathrm{~m}$ in $120-150$ min after the injection expressed in absolute values are sumarized 1n table 6.3.

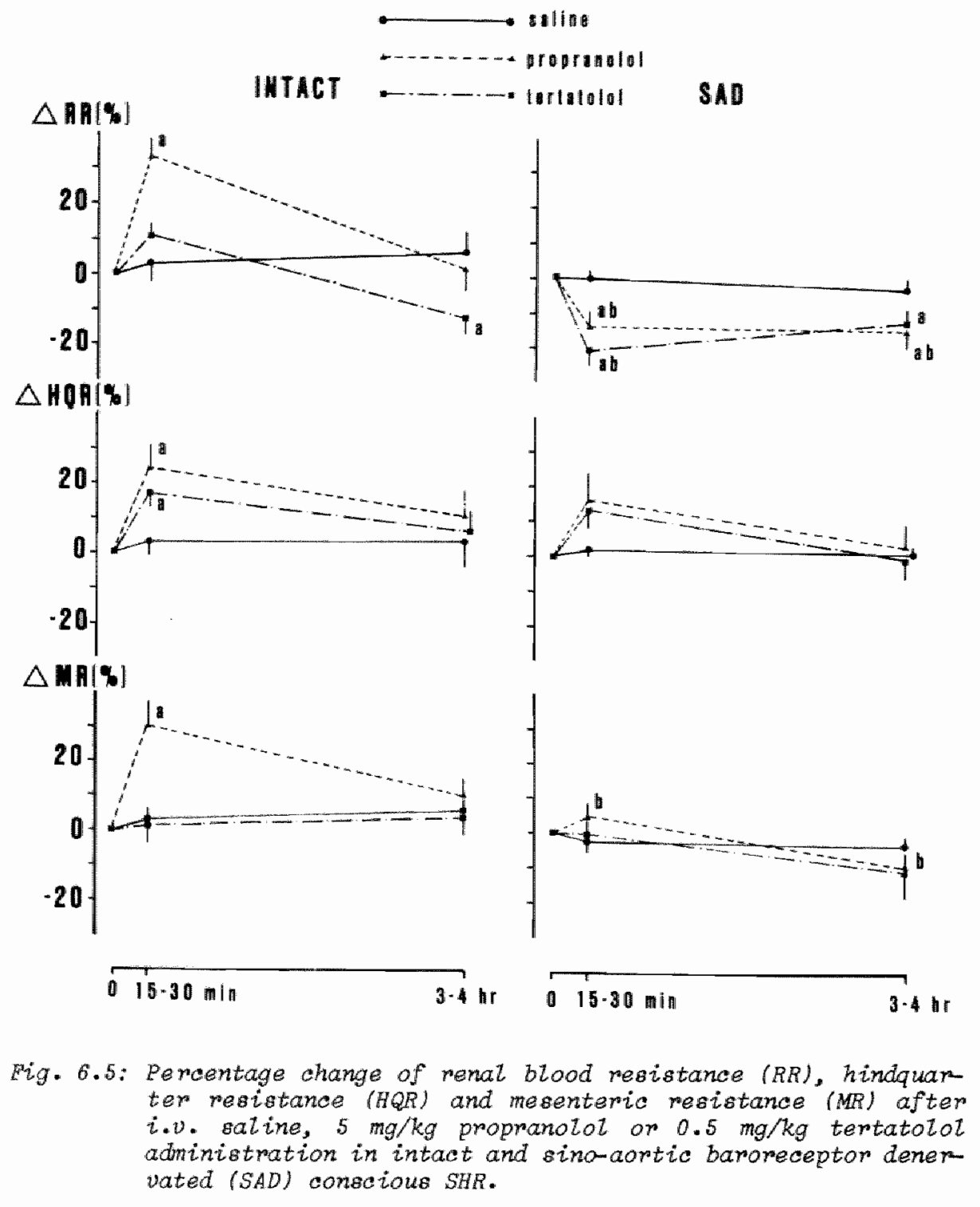


Table 6.3: Effects of intmavenous injections of atine $10.1 \mathrm{mll}$, prom pranolol (5 mg/kg), tertatolol $10.1 \mathrm{mg} / \mathrm{kg}$ and $0,5 \mathrm{mg} / \mathrm{kg}$ ) on ERPF (mL/min.g kw), GRR (ml/min.g kw), $P_{F}$ and $V(\mu l / m i n \cdot g$ kW). Data are mean $\pm S B M . * p<0.05 ; * x<0.01$ : Bignifiaantly different from control values.

\begin{tabular}{|c|c|c|c|}
\hline & $-15-0$ min & $30-60 \mathrm{~min}$ & $120-150 \mathrm{~min}$ \\
\hline \multicolumn{4}{|l|}{$\mathrm{ERPF}$} \\
\hline saline & $3.4+0.4$ & $3.0+0.2$ & $3.3+0.5$ \\
\hline propranolol & $3.0+0.4$ & $4.1+0.6$ & $2.7+0.4$ \\
\hline tertatolol low dose & $3.1 \mp 0.6$ & $4.0 \overline{+0.3}$ & $2.0 \overline{+0} .2$ \\
\hline tertatolol high dose & $3.6 \mp 8.5$ & $4.7 \mp 0.6 *$ & $2.7 \pm 0.5$ \\
\hline \multicolumn{4}{|l|}{ GFR } \\
\hline saline & $0.90+0.10$ & $0.90+0.07$ & $0.92+0.07$ \\
\hline propranolol & $0.92 \mp 0.18$ & $1.06+0.13$ & $0.78 \overline{+0} .12$ \\
\hline tertatolol low dose & $0.69+0.11$ & $1.02+0.15$ & $0.58+0.08$ \\
\hline tertatolol high dose & $0.83 \mp 0.13$ & $1.04+0.11$ & $0.72 \mp 0.11$ \\
\hline \multicolumn{4}{|l|}{$\mathrm{FF}$} \\
\hline saline & $0.26+0.01$ & $0.31+0.03$ & $0.29+0.02$ \\
\hline propranolol & $0.30 \mp 0.02$ & $0.27 \overline{+0} 0.02$ & $0.30 \overline{+0} 0.02$ \\
\hline tertatolol low dose & $0.24+0.03$ & $0.25+0.02$ & $0.28+0.01$ \\
\hline tertatolol high dose & $0.25 \mp 0.02$ & $0.23 \mp 0.02$ & $0.29 \mp 0.03$ \\
\hline \multicolumn{4}{|l|}{$\mathrm{V}$} \\
\hline saline & $7.9+1.4$ & $4.3+1.0$ & $3.9+1.0$ \\
\hline propranolol & $5.4 \overline{+1.3}$ & $9.6 \mp 1.8 *$ & $3.5+0.8$ \\
\hline tertatolol low dose & $7.8 \overline{+1} .8$ & $12.0 \overline{1} 1.5 * *$ & $2.7 \overline{+0} .4$ \\
\hline tertatolol high dose & $6.9+2.7$ & $13.0 \mp 2.4 * *$ & $4.6 \mp 2.3$ \\
\hline
\end{tabular}

No significant dffferences were observed beween the pre-injection values for ERPE, GFR, $F F$ and $W$ in the 4 different experimental groups. Only $0.5 \mathrm{mg} / \mathrm{kg}$ tertatolol caused a significant Increase In ERPF at 30 to 60 min after injection.

ERPF was at control levels 120 to 150 min post-injection in the 4 experimental groups. A slight but significant Increase in GFR was observed after 30 to $60 \mathrm{~min}$ of adilinistration of either betablacker. After 120 to 150 min, GFR had returned to control values. In the case of $0.1 \mathrm{mg} / \mathrm{kg}$ tertatolol, GR decreased further to $0.58+0.08$ $\mathrm{ml} / \mathrm{min} \cdot \mathrm{g} \mathrm{kw}$ but this reduction was not signlftcantly different from control values. No statistically signiflcant differences were observed 
In urine excretion 15 to 0 min before the drug adminlstration between the 4 experimental groups. Thirty to $60 \mathrm{~min}$ after 0.1 and $0.5 \mathrm{mg} / \mathrm{kg}$ tertatolol and $5 \mathrm{mg} / \mathrm{kg}$ propranolol, urine excretion increased significantly compared to control injections. The urine excretion returned to control values after 120 to $150 \mathrm{~min}$.

\subsubsection{Long-term effects on reglonal hemodynamics}

Pre-infusion values of MAP (min $H g$ ) and HR (bpm) for the different experimental groups before the start of the Infusion (day 0 ) are presented in table 6.4 . No stat1stically signiflcant differences were observed between pre-infusion values. Percentage change in MAP, HR, renal, hindquarter and mesentertic flow and resistance during chronic propranolol, tertatolol or saline infusion are presented in fig. 6.6. Durlng long-term treatment wth both beta-blockers propranolol ( $p$ 0.05 ) and tertatolol ( $<0.001$ ), blood pressure was significantly reduced to new steady-state levels 3 days after the start of the infuslon. Blood pressure was reduced more during infusion of tertatolol

Table 6.4: Pre-infusion values (means $t S E M$ ) of MAP (mo Bg) and $H R$ (bpm) of the galine, $5 \mathrm{mg} / \mathrm{kg} \cdot d$ propranolol and $0.5 \mathrm{mg} / \mathrm{kg} \cdot \mathrm{d}$ tertatolot treated group in the long-term regional hemodynomic study.

n MAP HR

$\begin{array}{llll}0.9 \% \mathrm{NaCl} & 13 & 155+3 & 315 \pm 11 \\ \text { Propranolol } & 7 & 148 \pm 4 & 339 \pm 7 \\ \text { Tertatolo1 } & 7 & 169 \pm 4 & 332 \pm 7\end{array}$

than during propranolol Infusion $(-28+1 \%$ and $-12+1 \%$, respectively). Both beta-blockers caused a fall ( $-8+2 \% ; p<0.05$, and $-13+3 \% ; p<0.001$ respectively) in HR. This effect was significant from the second day and did not change on subsequent days.

Propranolol reduced renal blood flow significantly $(p<0.05)$ to 
a new steady-state level during the first infusion day. No change In renal blood flow was observed in the case of tertatolol. Both betablockers simillarly reduced hindquarter flow during the first $2-3$ days of infusion to a maximum of $-31+6 \%$ ( $p<0.001$ ) in the case of propranolol and $-28+3 \%$ ( $p<0.001$ ) in the case of tertatolol. Thereafter, for both drugs a little increase in hindquarter flow was observed.

Also the effect on MF was nearly equal for both beta-blockers. MF was reduced during the first two infusion days. This significant reduction was slmflar during the following infusion days (maximally

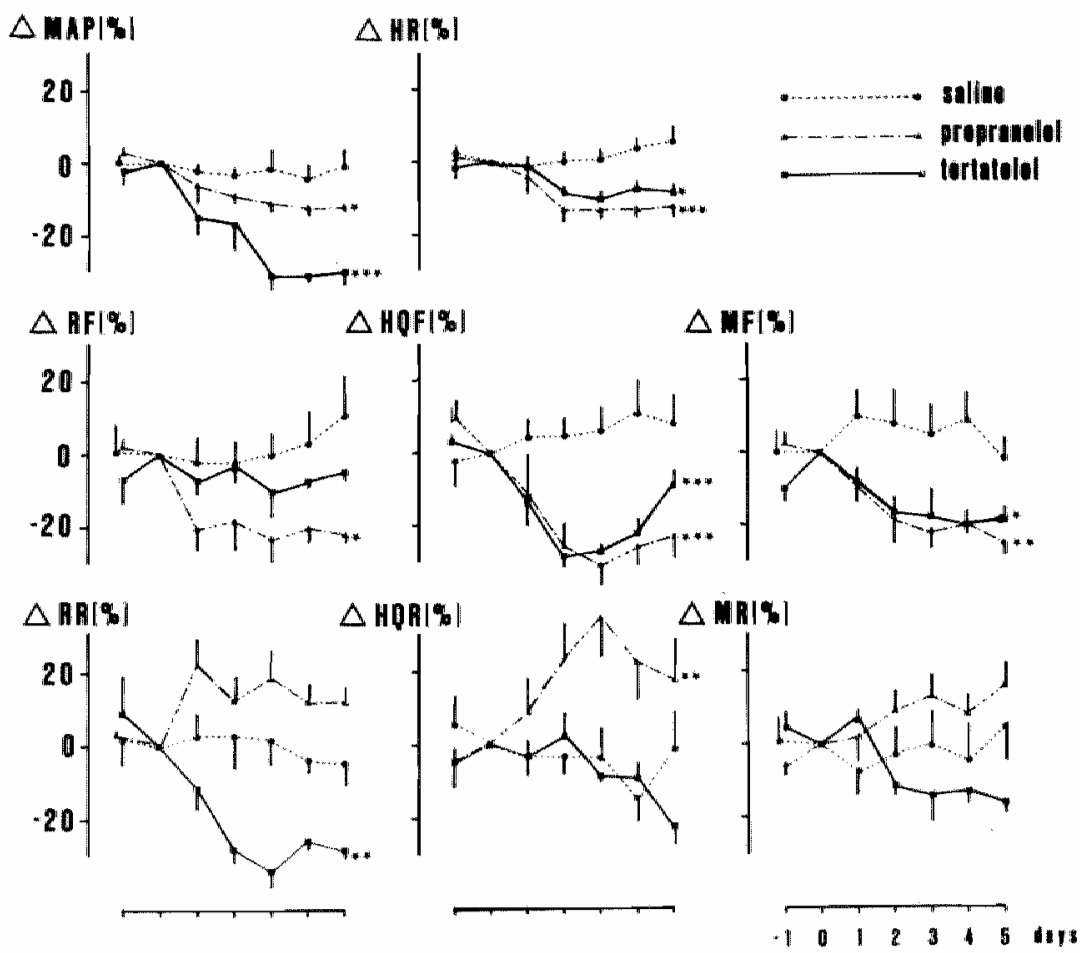

Pig. 6.6: Ejfects of tong-term infusion of baline $(24 \mu \mathrm{k} / \mathrm{d})$, propranolol $(5 \mathrm{mg} / \mathrm{kg}$.d) and tertatolol $(0.5 \mathrm{mg} / \mathrm{kg} \cdot \mathrm{d})$ on mean arterial preasure (MAP), heart rate (HR), renal flow (RP), hindquarter flow (HQF), mesenteric flow (ME), renal resistance (RR), hindquarter reatatance (HQR) and mesenterio reaistance (MR) in conbctous SHR. Significances are given in comparison with the baline infusion: "p<0.05; "p<0.01; $* * * p<0.001$. 
$-20+4 \%, p<0.05$ and $-25+3 \%, p<0.01$ for tertatolol and propranolol respect (vely).

Reglonal resistance changes yere calculated from pressure and flow changes. Tertatolol significantly $(p<0.01)$ reduced RR but did not Influence HQR and sightly but not significantly reduced MR. Propranolol increaged renal, hindquarter and mesentertc resistance but only the effect on HQR was significantly different from the control values ( $p<0.01)$. The slight reduction in MR during chronic tertatolal treatment was gignificantly diferent from the slight increase in $\mathrm{MR}$ in the case of propranolol $(p<0.001)$.

\subsubsection{Long-term effect on plasma renin concentration}

The values of MAP, HR and PRC just before the start and after 4 days of Infusion of $5 \mathrm{mg} / \mathrm{kg} \cdot \mathbb{d}$ propranolol, $0.5 \mathrm{mg} / \mathrm{kg} \cdot \mathbb{d}$ tertatolol and saline are sumarlzed tn table 6.5.

Long-term infusion of propranolol and tertatolol significantly reduced MAP and $\mathrm{HR}$. PRC was significantly reduced $(37 \%, \mathrm{p}<0.05)$ in the case of propranolol, but not during tertatolol.

Table 6.5: Blood preasume (MAP, mm Hg), heart rate (HR, bphl and plasma renin activity (PRC, ng $A I / m L$.hn) in the different experimental groups just before (day o) and after a 4-day infusion period of the respective drugs. Data are expressed as mean \pm SEM. Significances are given in comparison to pre-inf"ustion values: "p<0.05; *p<0.01; **p<0.001.

D Day MAP HR PRC

$\begin{array}{llllll}0.9 \% \mathrm{NaCl} & & & & & \\ (0.1 \mathrm{ml}) & 6 & 0 & 167+7 & 325+7 & 7.1+0.8 \\ & & 4 & 168 \pm 7 & 338 \pm 9 & 7.5 \pm 1.1 \\ & & & & \\ & & & & \\ \text { Propranolol } & 11 . & 0 & 170+4 & 328+10 & 8.4+0.8 \\ (5 \mathrm{mg} / \mathrm{kg} * \mathrm{~d}) & & 4 & 137 \pm 4 * * & 297 \pm 5 * & 5.3 \mp 0.5 * \\ & & & & & \\ \text { Tertatolol } & 7 & 0 & 174+3 & 358+6 & 8.1+1.2 \\ (0.5 \mathrm{mg} / \mathrm{kg} * \mathrm{~d}) & 4 & 139 \pm 5 * * & 304 \pm 13 * * & 7.5 \pm 1.3\end{array}$




\subsection{Discussion}

In this study we compared the hemodynamic actions of the nonselective betablockers propranolol and tertatolol in consclous unrestrained SHR, instrumented for continuous measurements of central or regional hemodynamic variables.

The cholce of dosages for the two drugs was based upon a study by Laubie et al (1973). In that study simllar beta-adrenoceptor blockade was observed for propranolol in dogs at doses of a factor tentwenty higher than for tertatolol. Because in most in vivo studies in rats (Davy et a1, 1977; Smits et al, 1980a,b, 1982; Struyker-Boudier et al, 1979) $5 \mathrm{mg} / \mathrm{kg}$ propranolol was used as a maximal $1 . \mathrm{v}$. doses, in our studies a slmilar dosage was used for propranolol and $0.5 \mathrm{mg} / \mathrm{kg}$ was used as a maximal dosage for tertatolol.

Our data conflrm previous reports on the time dependent effects of beta-adrenoceptor blockers (Smits et al, 1979, 1982). Thus, an immediate reduction of cardiac output was observed whereas the change in MAP consisted of an early rise, followed by a later decrease. The early rise in MAP was more pronounced in the case of tertatolol compared to the early effect of propranolol on MAP, reported by Smits et al (1982). Previous studies (Struyker-Boudier et al, 1979; S四its et al, 1982) showed that the hemodynamic action of propranolol consist of an acute as well as of a long-term reduction in cardiac output, whereas the lack of acute decrease in blood pressure 1. caused by a baroreflex medtated rise in total pertpheral restatance (TPR). This hemodynamic pattern suggests that the fall, in cardiac output rather than blood pressure triggers a baroreflex response. Experiments by Charlton and Baertschi (1982) Indicate that in the rat a change in aorta blood flow can indeed affect baroreflex actlutty. Cardiac output decreased to a similar extent in the case of $0.5 \mathrm{mg} / \mathrm{kg}$ tertatolol in our study as compared to that of $5 \mathrm{mg} / \mathrm{kg}$ propranolol described by Smits et al (1982). If we assume that the reduction in cardiac output is responsible for the increase in. TPR we would expect a slower increase in TPR in the case of tertatolol as compared to propranolol. However, this was not found in our study. We observed a 
sLilarly fast lacrease in TPR after tertatolol as was reported for propranolol. These results suggest that tertatolol may have a direct vasoconstricting or baroreflex stimulating activity, or propranolol may have direct vasodllating or baroreflex reduclng activity at several not measured vascular beds.

We furthemore investigated the posstble differences in regional sensitwity of different vascular beds in the vasoconstrictor effects of beta blackers. Other authors, using the microsphere technique in several animal models, showed that propranolol causes an early generalized Increase in vascular resistance in a number of vascular beds (Nies et al, 1973; Van Boom and Saxena, 1983; Hatzinikolaou et a1, 1983). Also in clinical experiments, a rise in vascular restatance was observed in different vascular beds, following the acute administration of propranolol (cf. Fitzgerald, 1984; Van Baak et al, 1985). Again, our data confirm these observations for propranolol. since this drug caused a comparable increase in vascular reslstance in the renal, hindquater and mesenterlc beds. Tertatolol clearly differs from propranolol with respect to its reglonal hemodynamic effects. Tertatolol caused an early increase only in hindquarter resistance. Rise in renal and mesenteric resistances were not observed and $3-4 \mathrm{hr}$ after bolus injection of tertatolol renal resistance was even decreased. From the central hemodynamic studies we would expect a more pronounced Increase In reglonal resistances in the case of tertatolol as compared to propranolol. However, the reverse was observed in the reglonal hemodynamic study. This suggest that tertatolol causes a vasoconstriction in other vascular beds than were studied in our reglonal hemodynamic study.

We have Investigated the role of the baroreflex in these reglional hemodynamlc effects of both betablockers in conscious $\mathrm{SHR}$. For this purpose we determined these effects in intact and baroreceptor denervated animals. After removal of the sino-aortic baroreflex control, propranolol and tertatolol behaved similarly. A reduction in renal, an increase in hindquarter and no effect on mesenteric resistance was observed for both beta-blockers in denervated rats. These results suggest that tertatolol reduces the baroreflex medlated constriction in the renal and mesenteric vascular beds in intact animals. 
Furthermore, these results indicate that tertatolol may accentuate a baroreflex medlated vasoconstriction in other vascular beds with an exception for the hindquarter. In the muscular vascular bed a role of the baroreflex can be excluded.

The question can be raised trough what mechanlsms tertatolol interferes with the baroreflex. Verbeuren et al (1985) showed that tertatolol has a high affinity for prejunctional beta-adrenoceptors in sympathetic nerve terminals in the dog saphenous vein. Thus it blocked the increased stimulation evoked overflow of noreptnephrine induced by 1soprenaline. So it seems attractive to speculate that the lack of vasoconstrictor activity of tertatolol in some vascular beds is due to its prejunctional effect. However, Laubie et al (1986) reported that pressor responses to a number of constrictor agents (BaCl${ }_{2}$, serotonin) are Inhibited by tertatolol, but not by propranolol or nadolol. This would suggest a non-adrenoceptor effect of the drug 1 in the renal and mesenteric vasculature.

A alternative hypothesis for the mechanism by which tertatolol Influences the baroreflex medlated effects could be that it interferes with central sites involved in the baroreflex pathway. Such an Interference was suggested for atenolol by Scott (1983) and Scott and Williams (1982) in anesthethed cats. Interaction studies of tertatoLol with sites in the central nervous system have not yet been reported.

We have shown above that the baroreflex plays an Important role in the acute reglonal hemodynamic effects of both beta-adrenoceptor blockers. On the long-tern the Influence of baroreceptor reflex mechantsms may be less dominant, because of adaptation of these mechantsms to the prevalling level of blood pressure. Therefore we extended our study on reglonal hemodymanles to their chronic appllcation.

During long-tern treatrent, propranolol induced silght increases in renal and mesenterlc resistances and a pronounced increase in hindquarter resistance. In the case of tertatolol hardly any changes in hindquarter and mesenterlc reslstance were observed but renal resistance decreased stgniflcantly during long-term treatment. The long-term changes are almost simllar to the acute reglonal hemodymanic 
changez, mieasured in sino-aortlc baroreceptor denervated animals in the case of certatolol. This in contrast to propranolol whose longter hemodynamic effects were beter comparable wh the acute regional hemodyamic effects in the intact animals. These results suggest a more rapld baroreceptor resetting during long-term tertatolol treatment as conpared to propranolol. Possibly this difference in baroreflex resetting for both beta blockers is based on their difference in renal perfuston. In the case of propranolol an acute and long-tern reduction in renal blood flow was observed. This in contrast to tertatolol that did not change renal blood flow. Moss (1986) has reported that a reduction in renal perfusion induces an excltation of renal afferent nerves. Furthermore, Janssen et al (1986) have shown that interruption of renal afferent nerves changes the baroreflex sensituity. So it cannot be excluded that long-tern differences in renal perfuston may leed to differences in baroreceptor resetting. This has to be further investigated.

In the acute situation and during chronic tertatolol treatment renal blood flow was left intact. This in contrast to the reduction in renal blood flow seen in the case of propranolol. This effect of tertatolol on renal vasculature may have important therapeutic implications since it may be expected to promote excretion of water and sodium (Borst and Borst-de Geus, 1963; Guyton et a1, 1979). Therefore we extended our study with acute renal hemodynamic and excretory function measurements in consclous SHR.

In these studies we found that in contrast to the significant reduction in renal blood flow in the reglonal hemodynamlc study the effective renal plasma flow (ERPF) was not affected after propranolol in the renal hemodynamte study. In the case of tertatolol no change in renal blood flow but an increase in ERPF was observed. The clearance of para-aminohippurate (PAH) was used to determine ERPF. Because PAH is excreted in the cortlcal part of the kldney. So the differences seen between renal blood flow and ERPF after beta blockade Indicate an intrarenal redistribution of flow to the cortex of the kidney possibly as a consequence of a medullary vasoconstriction induced by beta-adrenoceptor blockade. De Leeuw et al (1982) observed a better cortical renal blood flow in hypertensive patients treated wh propranolol as 
compared to non-treated hypertenslve subjects. These observations support our suggestion for the difference seen between renal blood flow and ERP after beta-blockade.

No differences in GFR were observed as compared to control values for both beta-blockers. Furthermore both arugs lnduced a considerable diurests. These results suggest a beta-adrenoceptor mediated reduction in tubular reabsorption. These observations differ from previously published results by Lauble et al (1986). They found that in contrast to propranolol, tertatolol increased GFR and urine and sodium excretton in consclous dogs. In these studies they observed no effect of both beta blockers on ERPF. In another study the same fnvestigators (Lantz et al, 1984) observed fncreases in ERPF and GRR in hypertensive patlents given tertatolol orally, Possibly these different experimental results can be explained by spectes differences because a similar effect of propranolol on urine excretion was observed by Smits et al (1982) in consclous SHR. He suggested an involvement of the sympathetic nervous system in the diuretic and natriuretic effects of propranolol. This hypothesis was supported by other investigators. Bencsath et al (1979) showed that renal sympathectomy $1 \mathbf{n}^{-}$ creased sodium and water excretion in rats. Schrier (1972), Besarab et al (1977) and Bello-Reus (1980) showed that beta adrenoceptors are Involved in the increase of tubular reabsorption of water and sodium durling renal nerve stimulation. These authors suggest that renal sympathetic nervous activity has an inhibitory effect on water and sodium excretion through beta-adrenergic mechanisms and consequentry blockade of beta- adrenoceptors may lead to a diuresla and natriuresls by reductng tubular reabsorption. Struyker Boudier et al (1986) reported that high amounts of beta-adrenoceptor binding sttes are present in the rat kldney tubulus. These observations support the above hypothesis.

Several Lnvestigators, however, showed that the increased tubular reabsorption of water and sodium is mediated through alphaadrenergic mechanisms (DIBona, 1977; DiBona et al, 1977; Collndres et al, 1978$)$.

Besides an influence via beta-adrenoceptors in the kidney also hormonal changes may be involved in these tubular effects. A possible 
candidate could be the renin-anglotensin-aldosteron system. A reduction in plasma renin concentration (PRC) and consequently a decrease in anglotensin II and aldosteron might provide an alternative explanathon for the duresls seen after beta-blockade. Beta-adrenoceptor blocklng agents reduce PRC in rats (Bühler et al, 1972; Leenen and Ackermann, 1976; Fermandes et al, 1976, 1977; Niarchos et a1, 1977; Hopak et al, 1977; Caputi et a1, 1978; Gulati and Liard, 1979, Smits, 1980b). In our study we measured plasma renin concentration after a Lour days lnfusion pertod of both beta blockers. We observed a reduction In PRC in the case of propranolol. However, no change in PRC was observed during long-term tertatolol treatment. It is not unlikely that in the case of propranolol the renin anglotensin aldosteron system is Involved in the observed tubular effects.

In concluston, our data show that activation of the sinoaortic baroreflex plays an important role in the early and long-term hemodynanic effects of both beta blockers propranolol and tertatolol. Furthermore, the data suggest that the absence of an increase in renal and mesenterlc reslstance following tertatolol is related to an interaction of the drug with the sympathetic nervous system mediated reflex vasoconstriction. Tertatolol thus protects the kidney fram a renal hypoperfusion as was observed for propranolol. This could have a potentlally therapeutic advantage in the treatment of hypertension. 


\section{CHAPTER 7}

HEMODYNAMIC EFEECTS OF TRE RENAL VASODILATOR PRODRUG CGP $22979 \mathrm{~A}$ AND ITS PARENT COMPOUND CGP $18137 \mathrm{~A}$ IN CONSCIOUS SHR

\subsection{Introduction}

Vasodilator drugs with a selective or preferential rent action (see chapter 1) have been suggested to have a potential usefulness in disease states such as hypertension and renal fallure (Struyker boudier, 1980; Ackermann et al, 1982, 1983) although others have challenged this suggestion (Brenner et al, 1982). Selective renal vasodilation is described for converting enzym inhibitors (Richer, 1983; 0liver et al, 1983; Smits et al, 1984) and for several naturally accurring prostaglandins. Also beta-blockers which maintain normal renal perfusion 1ike tertatolol (Lanz et at, 1984; chapter 6 of the thesis) and nadolol (Danesh et al, 1984) may be mentloned tn this respect. Furthermore, substances were developed like $(+)-4-3-3-[2-(1-$ hydroxycyclohexyll-ethyl]-4-oxo-2-thiazolidinyl propyl benzole acid, which dillates the renal vasculature through interference with prostaglandin mechanisms (Blalne et al, 1982; Seymour and Blaine, 1983), and fenoldopam (SK\&F 82526), which is thought to cause renal vasodilation through stimulation of postsynaptic dopamine $\mathrm{D}_{1}$ receptors in the kidney (Ackermann et al, 1982, 1983). Another possible approach was introduced by Hofbauer et al $(1985)$, i.e. the use of the prodrug principle to achleve selectively or preferentially high concentrations of a vasodilator substance in the kidney. They described the pharmacology of the prodrug CGP $22979 \mathrm{~A}$ in anesthetized rats and compared $4 t$ to that of ths parent substance CGP 1.8 137A. Thus, in CGP 22 979A, an

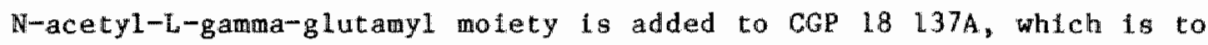
be regarded as a hydralazine-like vasodilator. Sequential hydrolysis by acylase and glutamyltranspeptidase is needed in order to generate the active substance. These reactions occur in the kldney at a higher 
rate than in other tissues (Orlowst et al, 1980). Addition of an $\mathrm{N}-$ aceryl-L-gama-glutamyl molety to the rodel substance sulfamethoxazole has, for instance, been shown to result in a highly selective accumulatlon of the active compound in mouse kidneys (Orlowski et al, 1980).

The first purpose of the present study was to quantitate the acute reglonal hemodyaamic effects of CGP $22979 \mathrm{~A}$ to Investigate Itts renal specificity. These effects were compared with the reglonal hemodynamles of 1 tes active compound CGP 18 137A.

Computer simulation studies suggest (see chapter 1) that selective renal vasodilation lexds to an acute diurests and natriuresis decreasing blood volume and, consequently, cardlac output. Such a diuresLs was expertmentally confirmed for CGP $22979 \mathrm{~A}$ by Hofbauer et al (1985) in anesthetlzed rats. We extended our studies to investigate central and renal hemorlynarics and renal excretory functions after bolus Injections of CGP $22979 \mathrm{~A}$ and CGP 18 137A in consclous SHR.

Furthermore, computer simulaton studies of selective renal vasodilators suggest a more pronounced reduction in blood pressure during long-term treatment induced by a slow reduction in TPR without a change in plasma anglotensin II levels. Therefore, we determined in addition the regional hemodynamic effects and the effect on plasma renin concentration of the possible preferential renal vasodilator CGP $22979 \mathrm{~A}$ and the hydralazine-like vasodilator CGP 18 137A during a continuous administration period of 5 days in consclous SHR.

\subsection{Experimental protacol}

\subsubsection{Anlmals}

Male SHR, weighting $250-350 \mathrm{~g}$, we re used in the studies described in this chapter. More details are presented in section 2.1 of this thesis.

\subsubsection{Central hemodynamic studies}

SHR used for these studies were instrumented as described in paragraph 2.3. On the experimental day, the animals were placed $i n$ $30 \times 20 \times 30 \mathrm{~cm}$ experimental cages. The arterial catheter was connected to 
a pressure transducer (CP-01; CTC, Inglewood, Ca, USA) to record blood pressure. MAP was obtained by low-pass filtering. The electromagnetic flowprobe was connected to a sine-wave flowmeter (MDL 400, Skalar, Delft, The Wetherlands). The flat part of late diatolic flow was taken to be zero. The mean aortc flow that was obtained by low-pass Filtering and which in fact constitutes co minus coronary flow, will be referred to furtheron as Co. HR was determined from the pulsatila flow signal using a biotacho-coupler (Narco, Mouston, TX, USA). All signals were monitored on a Grass mode1 7D polygraph (Grass Instruments, Quincy, MA, USA).

CI was calculated as CO/100 g bw. SVI was derived from CI and HR. TPRI was calculated as MAP/CI.

Injections were given after animals had been connected to the equipment for at least $1 \mathrm{hr}$. After determination of base-line values as the means of 4 consecutive readings 5 min apart, 1 .v. Infections of sallne $(0.1 \mathrm{ml})$, CGP $18137 \mathrm{~A}(0.3-1 \mathrm{mg} / \mathrm{kg})$ or CGP $22979 \mathrm{~A}(3-30 \mathrm{mg} / \mathrm{kg})$ were given and hemodynamics were montored for at least $4 \mathrm{hr}$. Values stated for hemodynamic parameters at 0.5 to 1 and 3 to $4 \mathrm{hr}$ are averages from 5 and 10 readings during these periods, respectively.

\subsubsection{Regional hemodynamic studies}

Surgery, measurements and calculations concerndng the reglonal hemodynamics were performed as described in paragraph 2.4. After connecting the head plug and catheters, the animals were allowed 1 to 2 hr to adjust to the experimental conditions. Arterial blood pressure was measured with a mintature pressure transducer (CP-01; CTC, Inglewood, CA, USA) connected to the artertal catheter. MAP was obtalned by electronic damping. HR was derived from the pressure slgnal using a Narco biotacho-coupler (Narco Blo-Systems, Houston, TX, USA). The Doppler probes were connected to a 4-channel $20 \mathrm{MHz}$ directional pulsed Doppler system (Bloengineering Department, Univeralty of Iowa, Iowa City IA, USA).

Injections were given in $0.1 \mathrm{ml}$ of $0.9 \% \mathrm{NaCl}$ and catheters were flushed slowly with $0.2 \mathrm{ml}$ of $0.9 \% \mathrm{NaCl}$. After the injection, slgnals were monitored continuausly for a period of 2 to $3 \mathrm{hr}$. Different dosages of the drug were given on different days fn random order. 
Seven animals recelved $0.3 \mathrm{ml}$ of $0.9 \% \mathrm{NaCl}$ after which paramecers were monltored for 1 hr. These animals served as controls.

In the long-term studies, surgery was extended with an Implantation of a jugular veln catheter (see paragraph 2.2.3). Regilonal hewodynamics were measured every day (during ca. $1.5 \mathrm{hr}$ ), one day before to 5 days after the start of the infusion of $1 \mathrm{mg} / \mathrm{kg} \cdot \mathrm{d}$ CGP $18137 \mathrm{~A}, 10$ $\mathrm{mg} / \mathrm{kg} \cdot \mathrm{d}$ CGP 22 979A or sallne. In these studies, doses of CGP $22979 \mathrm{~A}$ and CGP 18 137A were used as described in a prellminary study (Hofbater et al, 1986). After the measurements on day 0 , the infusion was started. For this purpose the drug containing Alzet minipump was connected to the jugular vein catheter and implanted under the skin of the 1 ightly ether anesthetized rat. The effects are expressed as percentage change from pre-infusion values measured on day 0.

\subsubsection{Renal henodynamic studies}

Glomerular filtration rate (GFR) and effective renal plasma flow (ERPF) were measured in consclous SHR as plasma clearances of $\left[{ }^{51} \mathrm{Cr}\right]-$ EDTA and [ ${ }^{125}$ I]PAH, respectively, as described in paragraph 2.8 "Method A". Durlng experiments, rats were in their own cages. Tracers were Injected Lmmediately after CGP 18 137A or CGP 22 979A or $3 \mathrm{hr}$ after adminlstration of the drugs. Thus, values of GFR and ERPF were obtalned for 0 to $1.5 \mathrm{hr}$ and 3 to $4.5 \mathrm{hr}$ after injectlons. Control animals received $0.3 \mathrm{ml}$ of $0.9 \% \mathrm{NaCl}$ lmmediately before tracers. At the end of the experiments, kidneys were renoved, blotted and welghed. GFR and ERPF are expressed as millilters per minute per gram of kidney welght. The fultration fraction (FF) was calculated as GFR/ ERPF.

\section{2 .5 Renal function studies}

Urine (V) and sodlun excretion $\left(\mathrm{U}_{\mathrm{Na}} \mathrm{V}\right)$ were quantitated in consclous SHR as described in paragraph 2.9 of this thesis. On the experimental day, the animals were placed in metabolic cages and sodium and water tutake was controlled. The outlet of the metabolic cages was connected to an LKB model 700 fraction collector which was set to change tubes every $120 \mathrm{~min}$. $V$ was determfned every $2 \mathrm{hr}$ by welighing the tubes. $\mathrm{Na}^{+}$concentration was measured usling a flame photometer. 
After 12 to $20 \mathrm{hr}$, bolus injections of CGP $18137 \mathrm{~A}(1 \mathrm{mg} / \mathrm{kg})$ or CGP 22 $979 \mathrm{~A}(3-30 \mathrm{mg} / \mathrm{kg})$ were given and $V$ and $U_{\mathrm{Na}} V$ were monitored for three more 2 hr periods.

\subsubsection{Plasma renin concentration studies}

Plasma renin concentration (PRC) was quantified by measuring the rate of angiotensin I (AI) formation by renin in plasma incubated under optimal conditions for renia (see paragraph 2.7).

The SHR used for these studies were implanted with an abdominal aorta and a jugular veln catheter (see paragraph 2.2.1 and 2.2.3). The arterial catheter was used for MAP and HR measurements and blood sample collection. The venous catheter was used for long-term Infuslons of CGP $18137 \mathrm{~A}$ ( $1 \mathrm{mg} / \mathrm{kg} \cdot \mathrm{d})$, CGP $22979 \mathrm{~A}(10 \mathrm{mg} / \mathrm{kg} * \mathrm{~d})$ or sallne using Alzet ${ }^{T M}$ osmotic minipumps. Similar doses were used as in the long-term reglonal hemodynamic studies. MAP and HR were measured every day (ca. 1.5 hr) one day before to 5 days after the start of the Infusion.

Blood samples $(250 \mu 1)$ were taken just before and after 4 days of infusion. Blood samples were centrifugated at $2000 \mathrm{rpm}$ and the plasma was stored at $-80^{\circ} \mathrm{C}$ unt 11 plasma renin activity was deternined.

\subsection{Results}

\subsubsection{Effects on central hemodynamics}

Base-1Ine values for the experimental groups used in central hemodynamic studies are sumarized in table 7.1 . There were no slgnif1cant differences between starting values in the different groups. Percentages of changes in hemodynamic parameters after saline, CGP 18 137A and CGP 22 979A are shown in fig. 7.1. Saline induced only minor changes at $0.5-1$ and $3-4$ hr after infection. CGP 18 137A caused $a$ rapid dose-depeadent reduction of MAP (cf. Fig. 7.1). This effect was assoctated with a steep fall in TPRI and increased CI because of a pronounced tachycardia and a slightly decreased SVI. At 3 to $4 \mathrm{hr}$ after injections, all effects were smaller than at 0.5 to 1 hr after injections (cf. flg. 7.1) although decrease in MAP and TPRI and in- 

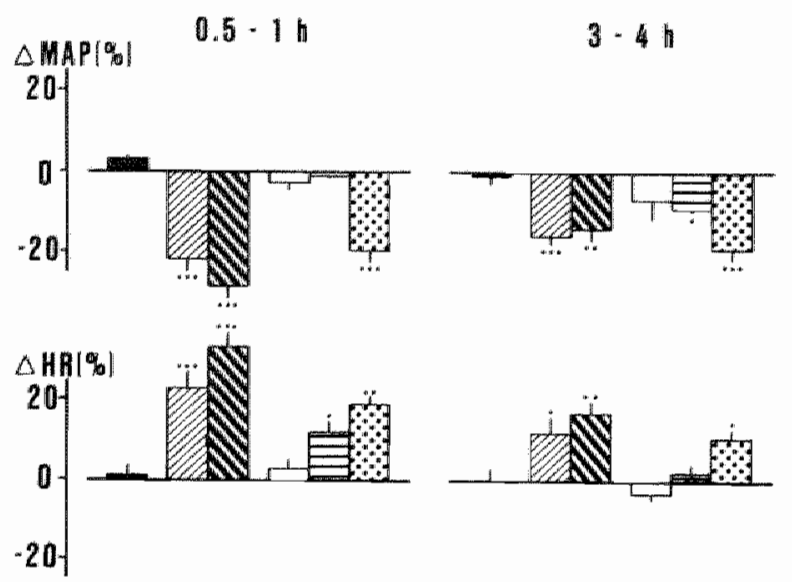

Saling $\{$ -
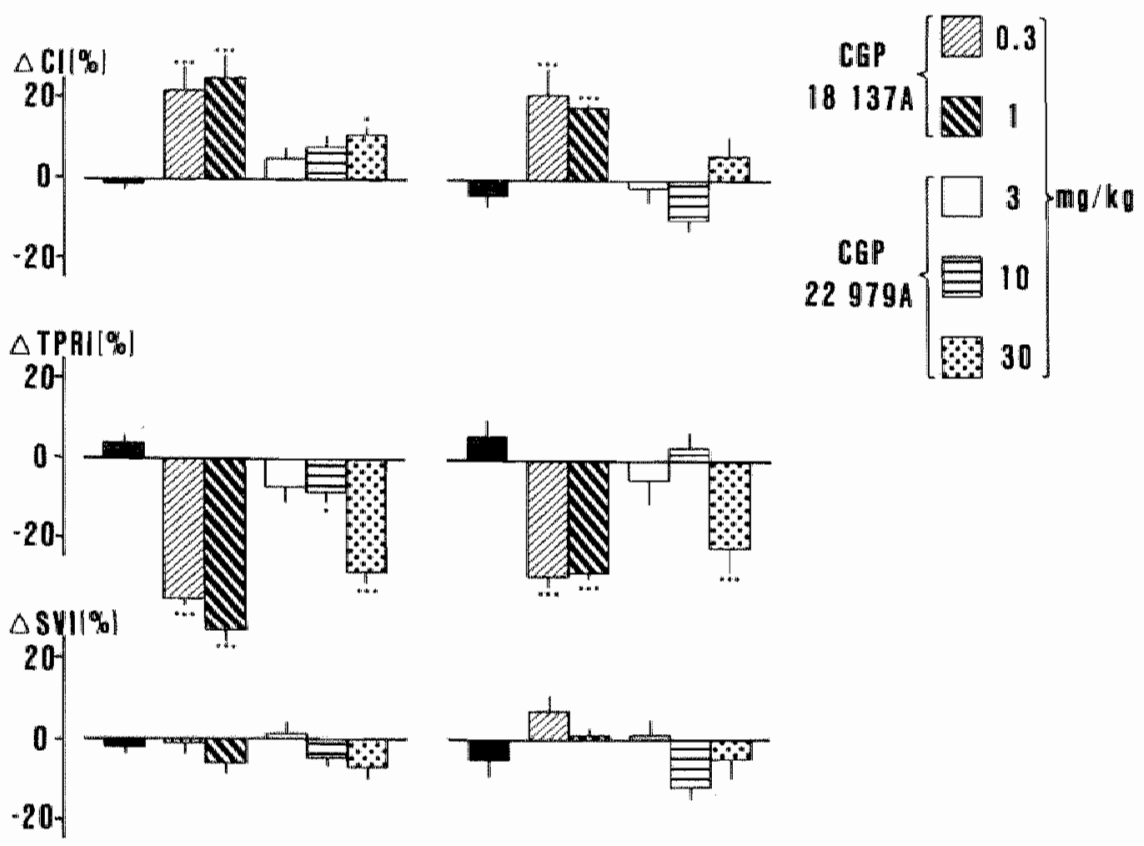

Fig. 7.1: Effects (pereentage changes) of satine, CGP 18 137A and CGP $22979 A$ on MAP, AR, CI, TPRI and SVI at 0.5 to $1 \mathrm{hr}$ reapectively 3 to 4 hr after injections. Significances in differences with saline: *p<0.05; * $0<0.01 ; * * 0<0.001$. 
Table 7.1: Pre-injection values of MAP, MR, CI, TPRI and SVI in the experimental groups used for contral henodynonto studies.

\begin{tabular}{|c|c|c|c|c|c|c|}
\hline Treatment & $\mathrm{n}$ & $\begin{array}{l}\text { MAP } \\
\text { nom } \mathrm{Hg}\end{array}$ & $\begin{array}{l}\text { GR } \\
\text { bpan }\end{array}$ & $\begin{array}{l}\text { CI } \\
100 \mathrm{~g} \\
\text { bw }\end{array}$ & $\begin{array}{l}\text { TPRI } \\
\text { nm Hg/min } \\
100 \mathrm{~g} \text { bH * } \\
\mathrm{m} 1\end{array}$ & $\begin{array}{l}\text { SWI } \\
\mu 1 / 100 \mathrm{~g} \\
\text { bw }\end{array}$ \\
\hline Sallne & 10 & $139+3$ & $395+14$ & $31+3$ & $4.8+0.4$ & $79+7$ \\
\hline \multicolumn{7}{|l|}{$\mathrm{CGP} \quad 18 \quad 137 \mathrm{~A}$} \\
\hline $0.3 \mathrm{mg} / \mathrm{kg}$ & 7 & $130+4$ & $384+17$ & $34+1$ & $3.9+0.2$ & $88+3$ \\
\hline $1 \mathrm{mg} / \mathrm{kg}$ & 7 & $127 \pm 10$ & $372 \pm 20$ & $31 \pm 1$ & $4.2+0.5$ & $87+7$ \\
\hline \multicolumn{7}{|l|}{ CGP $22979 \mathrm{~A}$} \\
\hline $3 \mathrm{mg} / \mathrm{kg}$ & 6 & $142+7$ & $373+6$ & $31+3$ & $4.8+0.6$ & $84+8$ \\
\hline $10 \mathrm{mg} / \mathrm{kg}$ & 9 & $153 \mp 5$ & $398 \overline{9}$ & $32+1$ & $4.6+0.3$ & $81+4$ \\
\hline $30 \mathrm{mg} / \mathrm{kg}$ & 6 & $133+4$ & $396 \overline{+1} 4$ & $30 \overline{+2}$ & $4.5 \overline{+0} \cdot 3$ & $77+6$ \\
\hline
\end{tabular}

creases in $H R$ and $C I$ were still signiflcant.

The two lowest doses of CGP $22979 \mathrm{~A}$ ( 3 and $10 \mathrm{mg} / \mathrm{kg}$ ) did not cause immedlate changes in MAP. TPRI decreased slightly but signiflcantly after $10 \mathrm{mg} / \mathrm{kg} \quad(p<0.05)$. Howewer, this reduction $(-8+3 \%)$ was small as compared to the changes at 0.5 to 1 hr after even the lowest dose of CGP 18 137A $(-35+2 \%)$. HR increased $(+9+3 \% ; p<0.05)$ after 10 $\mathrm{mg} / \mathrm{kg}$, but $C I$ and SVI were not significantly affected (cf. fig. 7.1). At this time, the higher dose of CGP $22979 \mathrm{~A}(30 \mathrm{mg} / \mathrm{kg})$ did reduce MAP $(-20 \pm 3 \% ; p<0.001)$. TPRI was reduced $(-28+3 \% ; p<0.001)$. HR $(+19+2 \% ; p<$ $0.01)$ and $\mathrm{CI}(+11+2 \% ; p<0.05)$ increased only slightly, whereas sVI tended to decrease.

At 3 to $4 \mathrm{hr}$ after injections of all three doses of CGP $22979 \mathrm{~A}$, MAP was decreased (cf. fig. 7.1). Only th the group recelving $30 \mathrm{mg}$ / $\mathrm{kg}$, a signiflcant reduction in TPRI was noted. In the group injected wh th $10 \mathrm{mg} / \mathrm{kg}$, CI tended to fall $(-10+3 \%)$ whereas in the $30 \mathrm{mg} / \mathrm{kg}$ group, tt was not changed $(+6+5 \%)$. SVI was Insigniflcantly affected by $-12+3 \%$ and $-5+5 \%$, respectively in the 10 and the $30 \mathrm{mg} / \mathrm{kg}$ groups.

\subsubsection{Acute effects on regional hemodynamics}

Pre-injection absolute values for MAP and HR are sumarlized in 
Table 7.2: Preminection aboolute values of MAP and HR in the differ ent experimental groups waed in the regionat hemodymonic atudies.

\begin{tabular}{|c|c|c|c|c|}
\hline & $\begin{array}{l}\text { Dose } \\
(\mathrm{mg} / \mathrm{kg})\end{array}$ & $\mathrm{n}$ & $\begin{array}{l}\text { MAP } \\
\text { (mim } \mathrm{Hg} \text { ) }\end{array}$ & $\begin{array}{l}\mathrm{HR} \\
\text { (bpm) }\end{array}$ \\
\hline Saline & & 7 & $152+17$ & $350+24$ \\
\hline $\mathrm{CGE} \quad 18 \quad 137 \mathrm{~A}$ & $\begin{array}{l}0.1 \\
0.3 \\
1.0\end{array}$ & $\begin{array}{l}5 \\
7 \\
7\end{array}$ & $\begin{array}{l}140+18 \\
136 \pm 9 \\
149+11\end{array}$ & $\begin{array}{l}366+29 \\
383+54 \\
322+33\end{array}$ \\
\hline $\operatorname{CGP} 22979 A$ & $\begin{array}{l}1 \\
3 \\
10 \\
30\end{array}$ & $\begin{array}{l}5 \\
8 \\
8 \\
8\end{array}$ & $\begin{array}{l}159+25 \\
151+12 \\
154+18 \\
151 \mp 13\end{array}$ & $\begin{array}{l}308+45 \\
325+34 \\
331+44 \\
338+26\end{array}$ \\
\hline
\end{tabular}

table 7.2. Saline caused only minor changes in MAP, HR and the reglonal reststances. CGP $18137 \mathrm{~A}$ was injected in doses of $0.1 \quad(n=5), 0.3$ $(n=7)$ and $1.0 \mathrm{mg} / \mathrm{kg}(n=7)$. The time course of the reduction of MAP and increases in HR was comparable to those seen after hydralazine (see chapter 4). Also, with regard to its antihypertensive potency, CGP 18 $137 \mathrm{~A}$ ( $\mathrm{fig}$ * 7.2) was fully comparable to hydralazine (see fig * 4.4). A maximal reduction of MAP by $41 \pm 7 \mathrm{~mm}$ Hg was observed after $1 \mathrm{mg} / \mathrm{kg} 1 . \mathrm{v}$. The effect of CGP 18 137A on HR tended to be greater than that after hydralazine. All three vascular resistances decreased significantly at all doses of CGP $18137 \mathrm{~A}$ tested (cF. Fig. 7.2). Although the effects on MR were comparable to those of hydralazine, the effect of CGP 18 $137 \mathrm{~A}$ on HQR was Ldentical to that of hydralazine only at the two lowest doses, whereas $1 \mathrm{mg} / \mathrm{kg}$ of CGP 18 137A decreased HQR less. The reductions of $R R$, although signiftcant at all doses, were smaller after CGP $18137 \mathrm{~A}$ (fig. 7.2) than after hydralazlne (fig * 4.4). Thus, the reduction of $R R$ following hydralazlne and CGP 18 137A never exceeded that of $\mathrm{HQR}$ and MR.

CGP 22 979A was infected in doses of $1 \quad(n=5), 3 \quad(n=8), 10 \quad(n=8)$ and $30 \mathrm{mg} / \mathrm{kg}(\mathrm{n}=8)$. Signiflcant changes of MAP and HR were only seen after the two highest doses. These effects developed more gradually 

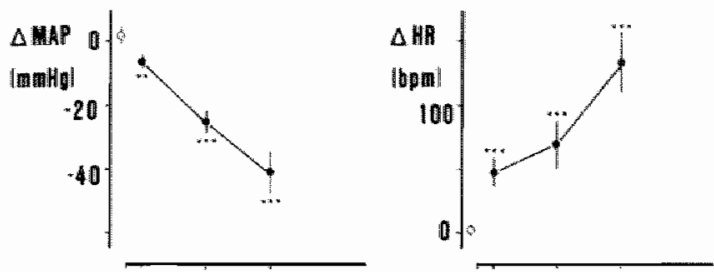

Hap 10. $197 \mathrm{Th}$
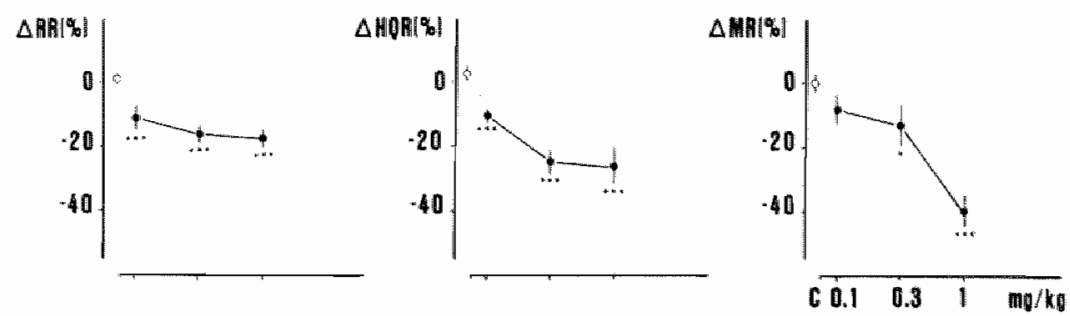

Fig. 7.2: Effects of CGP 18 137A on regional hemodynamics in conscious SHR. Significances are given in comparison to saline controle (C): *p<0.05; **p<0.01; ***0<0.001.
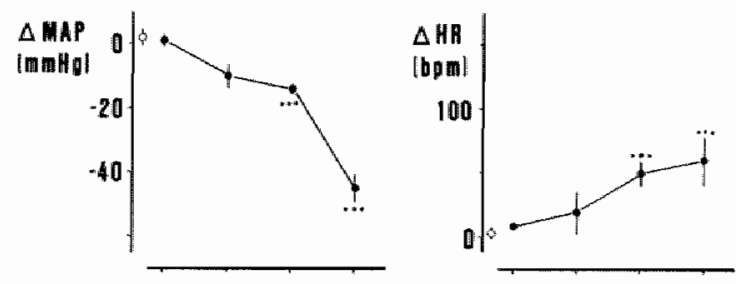

CGP $22979 A$
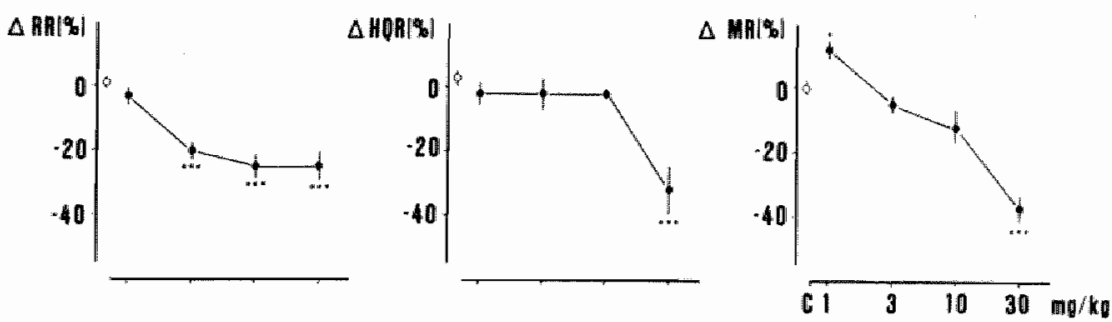

Fig. 7.3: Effects of saline and CGP 22 979A on regional hemodynomics in conscious SHR. Significances are given in comparison to saline controle (C): *p<0.05; **p<0.01; ***0.001. 
than those after hydralazdne or CGP 18 137A. A maximun decrease in blood pressure was obgerved after 45 to 60 min. The effects of CGP 22 $979 \mathrm{~A}$ are sumarlzed $\mathrm{fn} \mathrm{fIg}$. 7.3. The magnitude of the effect of 30 mg/kg of CGP $22979 \mathrm{~A}$ on MAP $(-44+5 \mathrm{~mm} \mathrm{Hg})$ was comparable to that of 1 国/ $/ \mathrm{kg}$ CGP 18 137A $(-41 \pm 7$ Hg), making it much less potent as an actully blood pregsure lowering agent. HR increased less with CGP 22 979 A than with the parent compound. Again, after the highest dose, it increased by $59+19$ beats/min, which is signiflcantly less (p<0.05) than the fncrease of $134+27$ beats $/ m i n$ seen after 1 mg $/ \mathrm{kg}$ of CGP 18 1374 .

$H Q R$ did not change significantly after 1 to $1.0 \mathrm{mg} / \mathrm{kg}$ of CGP 22 979A, whereas MR increased signiflcantly after $1 \mathrm{mg} / \mathrm{kg}$ and was not significantly changed after 3 to $10 \mathrm{mg} / \mathrm{kg}$ of $\mathrm{CGP} 22979 \mathrm{~A}$. Only after the highest dose of $30 \mathrm{mg} / \mathrm{kg}$ of CGP $22979 \mathrm{~A}$ a signiflcant decrease in HQR and MR was observed. In contrast, RR decreased significantly at all doses but the lowest. The maximal effect on RR was already seen after $10 \mathrm{mg} / \mathrm{kg}(-25+4 \%)$ after which dose nelther $\mathrm{HQR}(-2+2 \%)$ nor MR $(-12+5 \%)$ were decreased slgniflcantly. Thus, after 3 and $10 \mathrm{mg} / \mathrm{kg}$ of CGP $22979 \mathrm{~A}$, RR decreased to a greater extent than HQR and MR. After $30 \mathrm{mg} / \mathrm{kg}$, a comparable degree of reststance reduction was observed in the three vascular beds.

\subsubsection{Effects on renal hemodynamics}

The valules of GER, ERPF and FE measured 0 to 1.5 and 3 to 4.5 hr after bolus injections of saline, CGP $18137 \mathrm{~A}(1 \mathrm{mg} / \mathrm{kg})$ and CGP 22 $979 \mathrm{~A}(3-30 \mathrm{mg} / \mathrm{kg})$ are presented in $\mathrm{fig}$. 7.4. In saline-injected an mals, ERPF was $3.70+0.26 \mathrm{ml} / \mathrm{min} . \mathrm{g} \mathrm{kw}$. One $\mathrm{mg} / \mathrm{kg}$ of CGP $18137 \mathrm{~A} \mathrm{de-}$ creased ERPF to $2.85+0.49 \mathrm{ml} / \mathrm{min} . \mathrm{g} \mathrm{kw}$. at 0 to $1.5 \mathrm{hr}$, although this walue was not significanty different from the value after saline. At 3 to $4.5 \mathrm{hr}$, it was back to $3.41+0.42 \mathrm{ml} / \mathrm{min} . \mathrm{g} \mathrm{kw}$. CGP $22979 \mathrm{~A} \mathrm{in-}$ creased ERP dose-dependently at 0 to $1.5 \mathrm{hr}$ after 1 jjection. After 30 $\mathrm{mg} / \mathrm{kg}$, RPF was $4.9040 .17 \mathrm{ml} / \mathrm{min} . \mathrm{g} \mathrm{kw} .(\mathrm{n}=6 ; \mathrm{p}<0.05)$. At 3 to $4.5 \mathrm{hr}$ after injections of CGP $22979 \mathrm{~A}$, ERPF was still slightly lncreased $(4.38+0.29 \mathrm{ml} / \mathrm{min} \cdot \mathrm{g} \mathrm{kw}$. after $30 \mathrm{mg} / \mathrm{kg})$.

GFR was $1.17+0.12 \mathrm{ml} / \mathrm{min} \cdot \mathrm{g} \mathrm{kw}(\mathrm{n}=7)$ in saline-injected animals. CGP 181374 caused a rapld, significant $(p<0.001)$ reduction of GFR at 
$0 \cdot 2$ hours
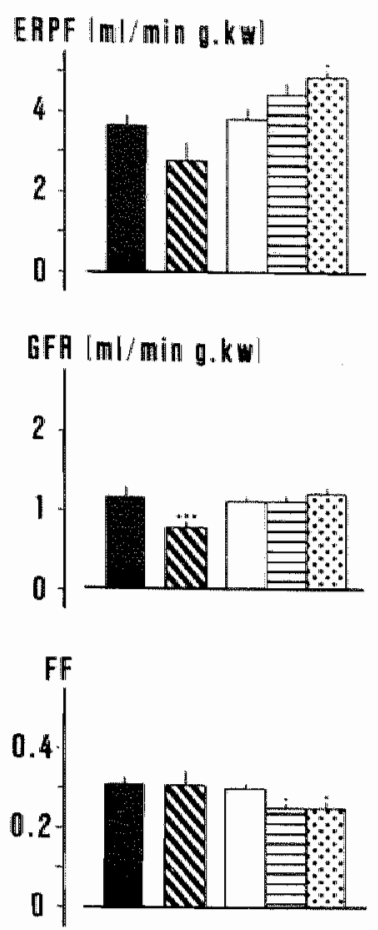

\section{$2 \cdot 4$ hours}
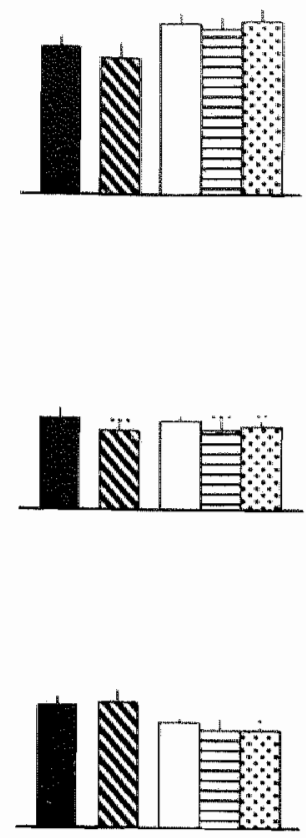

Eig. 7.4: Effects of saline, CGP 28 137A and CGP 22 979A on ERPF, GRR and $\mathbb{F F}$ at 0 to $1.5 \mathrm{hr}$ respectively 3 to $4.5 \mathrm{hr}$ after injection. Significances in differences with baline: ${ }^{*} p<0.05$. For symbole, see legend to fig. 7.1 .

0 to $1.5 \mathrm{hr}$ after injection $(0.79+0.06 \mathrm{ml} / \mathrm{min.g} \mathrm{kw} ; \mathrm{n}=6)$. At 3 to 4.5 hr after injection, it was still reduced. CGP $22979 \mathrm{~A}$ did not affect GF at O to $1.5 \mathrm{hr}$ after infection. At 3 to $4.5 \mathrm{hr}$ after injection, both 10 and $30 \mathrm{mg} / \mathrm{kg}$ reduced GFR slightly, but slgntflcantly ( $<<0.01$; cf. fig. $7 \cdot 4$ ).

After saline, FF was $0.31+0.02$. CGP $18137 \mathrm{~A}$ did not affect FF (cF. fig. 7.4). However, all doses of CGP $22979 \mathrm{~A}$ decreased FF. After $30 \mathrm{mg} / \mathrm{kg}$ it decreased to $0.25+0.02(\mathrm{p}<0.05)$ and this effect persisted at 3 to 4.5 hr after injection $(0.25+0.01 ; p<0.05)$. 
Table 7.3: Effects (means \pm SEH) of aline, CGP 18 137A and CGP 22 979A on diumesib and natmiumesis in conseious SHR. Significances in differenees with caline: "p<0.05.

hr poat injection

n $\quad-4$ to $-2 \quad-2$ to $0 \quad 0$ to $2 \quad 2$ to $4 \quad 4$ to 6

$V(\mathrm{ml} / 2 \mathrm{hr})$
Saline
8
$0.81+0.21 \quad 0.80+0.27 \quad 1.02 \pm 0.18$
$0.84+0.190 .90+0.37$
CGP $18 \quad 137 \mathrm{~A}$
$1 \mathrm{mg} / \mathrm{kg}$
$7 \quad 0.82+0.121 .03+0.14 \quad 0.69+0.25$
$0.58+0.291 .53+0.34$

CGP $22979 \mathrm{~A}$

$\begin{array}{llllllll}1 & \mathrm{mg} / \mathrm{kg} & 7 & 0.88+0.23 & 0.73+0.25 & 2.14+0.57 & 1.13+0.35 & 1.20+1.26 \\ 3 & \mathrm{mg} / \mathrm{kg} & 6 & 0.86 \mp 0.27 & 0.87 \mp 0.26 & 3.15 \mp 0.79 & 1.42 \mp 0.24 & 0.76 \mp 0.51 \\ 10 \mathrm{mg} / \mathrm{kg} & 7 & 0.85 \mp 0.16 & 0.72 \mp 0.19 & 3.33 \mp 0.58 * & 0.96 \mp 0.39 & 0.42 \mp 0.16 \\ 30 \mathrm{mg} / \mathrm{kg} & 7 & 0.67 \mp 0.09 & 0.71 \mp 0.07 & 3.48 \mp 0.61 * & 0.41 \mp 0.25 & 1.87 \mp 0.44\end{array}$

$\mathrm{U}_{\mathrm{Na}} \mathrm{V}(\mu \mathrm{Eq} / 2 \mathrm{hr})$

$\begin{array}{lllllll}\text { Saline } & 8 & 128 \pm 34 & 131 \pm 48 & 142 \pm 44 & 120 \pm 26 & 150 \pm 46 \\ \begin{array}{c}\text { CGP } 18137 \mathrm{~A} \\ 1 \mathrm{mg} / \mathrm{kg}\end{array} & 7 & 213 \pm 53 & 189 \pm 45 & 144 \pm 62 & 114 \pm 86 & 430 \pm 164 \\ \text { CGP } 22979 \mathrm{~A} & & & & & & \\ 1 \mathrm{mg} / \mathrm{kg} & 7 & 178 \pm 33 & 153 \pm 33 & 538 \pm 195 & 230 \pm 91 & 351+92 \\ 3 \mathrm{mg} / \mathrm{kg} & 6 & 168 \pm 42 & 168 \pm 39 & 492 \pm 149 & 200 \pm 42 & 149 \pm 73 \\ 10 \mathrm{mg} / \mathrm{kg} & 7 & 170 \pm 49 & 200 \pm 56 & 483 \pm 133 & 283 \pm 184 & 71 \pm+35 \\ 30 \mathrm{mg} / \mathrm{kg} & 7 & 112 \pm 29 & 122 \pm 32 & 509 \pm 148 * & 78 \pm 62 & 288 \pm 92\end{array}$

\subsubsection{Effects on renal excretory function}

EEfects of saline, CGP $18137 \mathrm{~A}$ and CGP $22979 \mathrm{~A}$ on diuresis and natrluresis are shown In table 7.3. Base-line values for dluresis were between 0.67 and $1.03 \mathrm{ml} / 2 \mathrm{hr}$, whereas sodfum excretion ranged from 128 to $213 \mu \mathrm{Eq} / 2 \mathrm{hr}$. There were no significant differences between base-1lne values for the groups. Saline caused only marginal changes In water and sodium excretion. CGP $18 \quad 137 \mathrm{~A}$ reduced $\mathrm{V}$ and $\mathrm{U}_{\mathrm{Na}} \mathrm{V}$ during the first two perlods, whereas it slightly increased them in the last 2 hr period. Changes were insignificant as compared to controls. CGP 22979 A caused a dose-dependent increase in dluresis during the first 
2 hr period (ef. table 7.3). Also $\mathrm{U}_{\mathrm{Na}} \mathrm{W}$ increased although there was no relationship between dose and magnitude of the increase. After this Initial increase, $\mathrm{W}$ and $\mathrm{U}_{\mathrm{Na}} \mathrm{V}$ decreased to values that were no longer different from those after saline.

\subsubsection{Long-term effects on regtonal hemodynamies}

Pre-infusion values of MAP (mm Hg) and HR (bpm) for the different experimental groups just before the start of infusion on day 0 are summarized in table 7.4 .

Table 7.4: Pre-infusion values (mean + SEM) of MAP ( $\mathrm{nm}$ Hg) and $H R$ (bpm) of the different experimental groups in the long-term regional hemodynomie study.

\begin{tabular}{lccc}
\hline & $\mathrm{n}$ & $\mathrm{MAP}$ & $\mathrm{HR}$ \\
\hline $0.9 \% \mathrm{NaCl}$ & 13 & $155+3$ & $315+11$ \\
$\mathrm{CGP} 18137 \mathrm{~A}$ & 8 & $168 \pm 5$ & $320+8$ \\
$(1 \mathrm{mg} / \mathrm{kg} \cdot \mathrm{d})$ & & & $333 \pm 10$ \\
$\mathrm{CGP} \mathrm{22} \mathrm{979A}$ & 10 & $162 \pm 4$ & $3 \mathrm{mg} / \mathrm{kg} \cdot \mathrm{d})$ \\
$(10$ & & & \\
\hline
\end{tabular}

There were no significant differences between starting values to the different groups. Changes in MAP and HR together with flow and resistance changes in the three vascular beds during long-term treatment with saline, CGP $18137 \mathrm{~A}(\mathrm{l} \mathrm{mg} / \mathrm{kg} \cdot \mathrm{d})$ and CGP $22979 \mathrm{~A}(10 \mathrm{mg} / \mathrm{kg} \cdot \mathrm{d}$ ) are presented in $\mathrm{fig}_{\mathrm{g}}$. 7.5. The effects are expressed as percentage change from the values measured just before the sart of the infusion.

During long-term infusion, both drugs significantly reduced MAP ( $p<0.001)$ compared to the saline-treated group. CGP 18 137A caused a rapld fall in blood pressure which was maximal 2-5 days after the start of the infusion. CGP $22979 \mathrm{~A}$ reduced MAP gradually during the whole infusion period. On day 5 , the MAP reduction was almost the same for CGP $22979 \mathrm{~A}$ and CGP 18 137A ( $-21 \pm 2$ and $-26+4 \%$, respectively). In 
contrast to the effect of CGP $22979 \mathrm{~A}$ on HR, HR was significanty increased during longmterm Infusion of CGP 18 137A ( $0<0.001)$ compared to control animals. This lncrease was almost equal from the second day $(+17+3 \%)$ to the and of the infusion $(+18+4 \%)$.

During long term CGP 18 137A treatment, flows in all vascular beds measured showed a trend to increase. Only in the case of the hindquarter, $t$ reached the level of signiflcance $(p<0.05)$. After 3 days infusion of CGP $18137 \mathrm{~A}$, HQF and MF returned to control values. $A$ slight temporary flow fncrease in the kidney but not in the mesentery

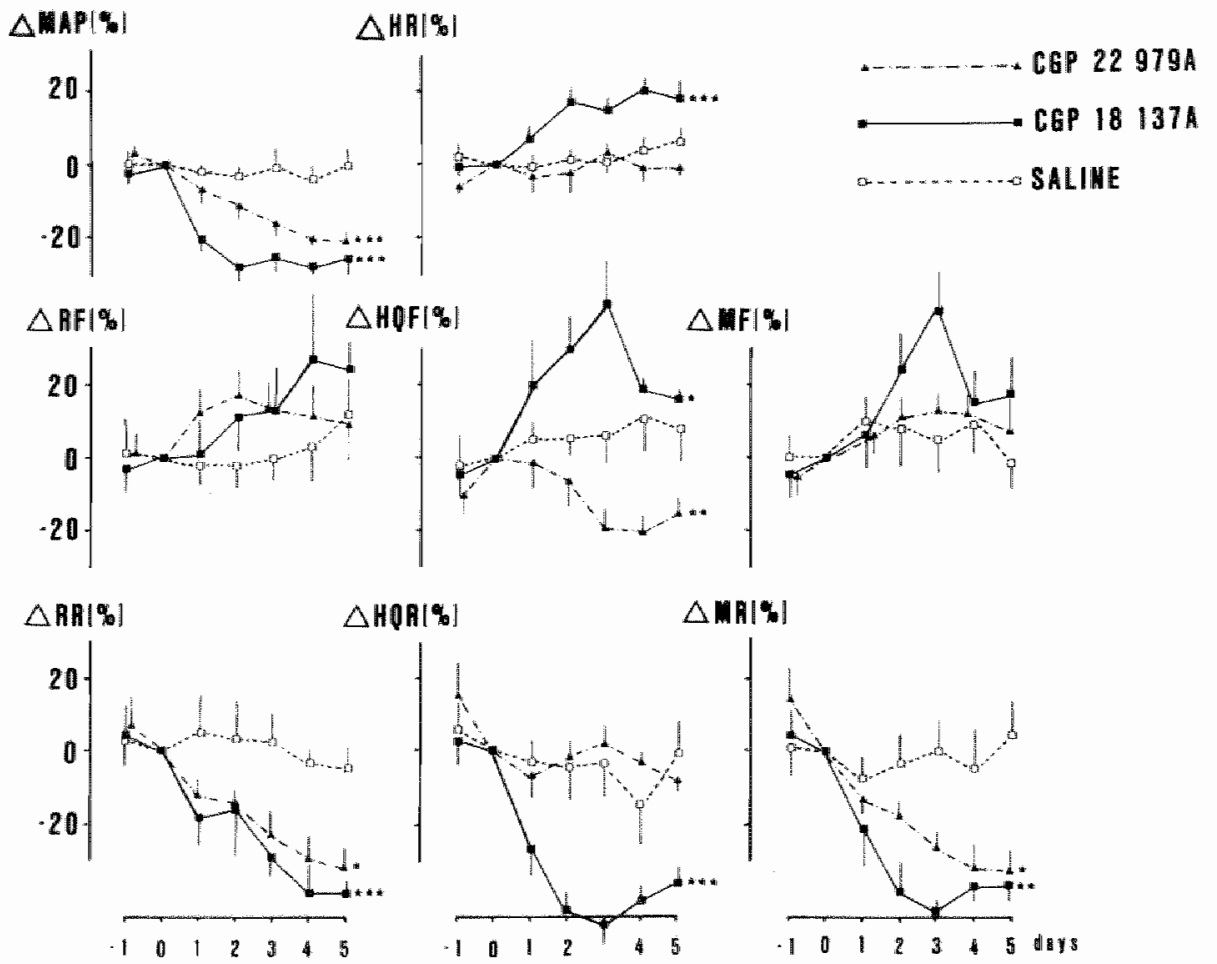

Ha. 7.5: Effact of Zong-term infusion of CGP $22979 \mathrm{~A}(10 \mathrm{mg} / \mathrm{kg} \cdot \mathrm{d})$. CGP $18137 \mathrm{~A} \mathrm{(1} \mathrm{mg} / \mathrm{kg} \cdot$ d) and sal ine on mean arterial preseure $(M A P)$, heart rate (HR), renal flow (RP), hindquarter flow $(H Q P)$, mesenteric flow (MF), renal resiatance $(R R$, hindquar ter resistance ( $H Q R$ ) and mesenteric resistance (MR) in conscious SHR. Stgnificances are given in comparison with the satine infusion: *p<0.05; * $p \times 0.01$; ***0<0.001. 
Table 7.5: Blood presewre (MAP, mm HG), heart pate (HR, bphl and plasma renin concentration (PRC, ng AI/Mit.hr) in the different experinental groups just before (day o) and after a 4-day period of the respective drugs. Data are expressed as mear * SEM. Sigrificances are given in comparison to pre infusion values: ***0.001.

\begin{tabular}{|c|c|c|c|c|c|}
\hline & $\pi$ & Day & MAP & HR & PRC \\
\hline $\begin{array}{l}0.9 \% \mathrm{NaCl} \\
(0.1 \mathrm{ml})\end{array}$ & 6 & $\begin{array}{l}0 \\
4\end{array}$ & $\begin{array}{l}167+7 \\
168 \pm 7\end{array}$ & $\begin{array}{l}325+7 \\
338+9\end{array}$ & $\begin{array}{l}7.1+0.8 \\
7.5 \pm 1.1\end{array}$ \\
\hline $\begin{array}{l}\text { CGP } 18 \text { I } 37 A \\
(1 \mathrm{mg} / \mathrm{kg} \cdot \mathrm{d})\end{array}$ & 8 & $\begin{array}{l}0 \\
4\end{array}$ & $\begin{array}{l}179+5 \\
121+3 * * *\end{array}$ & $\begin{array}{l}338+10 \\
396 \mp 19 * * *\end{array}$ & $\begin{array}{l}10.1+1.3 \\
22.1+3.4\end{array}$ \\
\hline $\begin{array}{l}\text { CGP } 22979 \mathrm{~A} \\
(10 \mathrm{mg} / \mathrm{kg} \cdot \mathrm{d})\end{array}$ & 6 & $\begin{array}{l}0 \\
4\end{array}$ & $\begin{array}{l}176+7 \\
129+8 * * *\end{array}$ & $\begin{array}{l}331+10 \\
332+14\end{array}$ & $\begin{array}{l}7.6+0.4 \\
8.7 \pm 1.6\end{array}$ \\
\hline
\end{tabular}

was observed during Infusion of CGP 22 979A. This in contrast to a signiflcant reduction in $H Q F(p<0.01)$ during the long-term treatment of CGP $22979 \mathrm{~A}$.

CGP $18137 \mathrm{~A}$ reduced $\mathrm{RR}, \mathrm{HQR}$ and $M R$. In the hindquarter and mesenteric vascular bed, this reduction was maximal $2-3$ days after the start of the Lnfusion. In the case of CGP $22979 \mathrm{~A}$, a reduction in RR and MR but no change in $H Q R$ was observed. In the kidney, this reduction was continuous and almost similar for both drugs during the whole infustion period. In the case of CGP $18137 \mathrm{~A}$, the reduction in MR was stronger during the Eirst 3 days of Infusion. Thereafter, MR increased to the same level as in the case of Cop $22979 \mathrm{~A}$.

\subsubsection{Long-term effect on plasma renin concentration}

The values of MAP, HR and PRC just before (day 0 ) and after 4 days infusion of the different experimental drugs are sumarlized in table 7.5. The data show no signiflcant differences between the preinfusion values of MAP and $H R$ in the different experimental groups. There were no significant differences between the pre-infusion values of different treated groups. Long-term Lnfuston of CGP 1.8 1.37A signiflcantly decreased MAP about $32 \%$, tacreased HR about $17 \%$ and 1 ncreased 
PRC by about $120 \%$ (compared to pre-infusion and control values). Longterm infuston of CGP 22 979A signiflcantly decreased MAP ( $<<0.001$ ) about $27 \%$, but did not change $H R$ and PRC.

\subsection{D1scussion}

CGP $18137 \mathrm{~A}$ is a hydralazine-1ike vasodilator, whereas CGP 22 $979 \mathrm{~A} 1 \mathrm{~s}$ the N-acety1-L-gamma-glutamyl substituted analogue of CGP 18 $137 \mathrm{~A}$ (Hofbauer et a1, 1985). Introduction of an N-acetyl-L-gamma-glutamyl molety has been suggested as a prodrug approach for obtaining selectively high renal concentrations of drugs because the release of the active compound through hydrolysis by acylase and gamma-glutamyl transpeptidase occurs at a higher rate in the kidney than in other tissues (Orlowski et al, 1980). In a previous study (Hofbauer et al, 1985), CGP 22 979A was shown to lack vasodilatory properties in an in-vitro preparation in which CGP 18 137A exerted a dose-dependent vasodilation. Moreover, in that study it was shown that in the intact, anesthetized rat, CGP $22979 \mathrm{~A}$ caused a preferential renal vasodilation (Hofbauer et al;, 1985). Because cardiovascular reflexes which are grossly attenutated in anesthetized animals (Cox and Bagshaw, 1974; Zimpfer et al, 1981) may modify the responses, we studied systemic and reglonal hemodynamic effects of the possible selective renal vasodilator In consclous unrestralned SHR.

The acute central hemodynamic effects of GGP 18 137A and CGP 22 $979 \mathrm{~A}$ fit into two categorles. CGP 18 137A and the highest dose ( 30 $\mathrm{mg} / \mathrm{kg}$ ) of CGP $22979 \mathrm{~A}$ cause an Immediate reduction of MAP which is assoclated with an immedate fall in $T P R$. This resembles the response pattern whlch we observed after the administration of the classical artertolar vasodilators hydralazine, dihydralazine and endralazine in consclous SHR (chapter 4). It also confirms the observations with regard to the acute non-selective vasodilatation after CGP $18137 \mathrm{~A}$ and high doses of CGP $22979 \mathrm{~A}$ in the regional hemodynamic study. In the case of CGP $18137 \mathrm{~A}$, this pattern is in fact to be expected because it Ls a hydralazlne-like compound. It seems $11 \mathrm{kely}$ that after $30 \mathrm{mg} / \mathrm{kg}$ CGP 22979 the release of the parent compound from the prodrug occurs 
at such a high rate that there is considerable splll-over of the active vasodilator into the general circulation.

Lower doses ( $<30 \mathrm{mg} / \mathrm{kg}$ ) of CGP $22979 \mathrm{~A}$ do not cause an lmined late reduction of MAP and TPR. They cause a late reduction of MAP with tendency towards ceduction of co. This effect resembles that of aluretics in SHR (Struyker Boudier et al, 1983) which cause a primary decrease of SVI and co. The resemblance flts with our observations with regard to rengl function changes.

The diuretic-1ike effects of CGP $22979 \mathrm{~A}$ on central hemodynamles are not only obserwed after the low doses. In fact, the rlse in co after $30 \mathrm{mg} / \mathrm{kg}$ of the prodrug is much smaller than after CGP $18137 \mathrm{~A}$. In a previous chapter, we have shown that the rise of co after hydralazine depends upon activation of the sino-aortic baroreceptor reflex. Therefore, one explanation for the smaller rise in comight be that CGP $22979 \mathrm{~A}$ interferes with the sino-aortic reflex. Alternatively, the effect on $C O$ represents a sumation of baroreflexes and the diuretic effect resulting in a lesser effect on co.

Hydralazine (see chapter 4 ) and CGP $18137 \mathrm{~A}$ were fully comparable with regard to their blood pressure lowering potencles. Thelr regional hemodynamic effects, however, differed. Qualitatively both drugs behave as general wasodilators.Hydralazlne lnduced larger decreases $1 n$ RR and $H Q R$ than CGP 18 137A. This may imply that CGP 18 $137 \mathrm{~A}$ dilates other vascular beds to a larger extent than hydralazlne. Alternatively, hydralazine may cause a larger drop in peripheral resistance at a comprable degree of blood pressure reduction This can only be the case tf hydralazlne causes a larger degree of reflex r tae in cardiac output. This does not seem likely because the rachycardia seen during a CGP 18 137A induced reduction of MAP tended to be greater than that observed during an equal reduction of MAP by hydralazine and $1.0 \mathrm{mg} / \mathrm{kg}$ CGP $18137 \mathrm{~A}$ increased CI more than $0.3 \mathrm{mg} / \mathrm{kg}$ hydralaztne (see chapter 4 ).

CiGP 22 979A was much less potent as an acute blood pressure lowerlng agent. Only doses of 10 to $30 \mathrm{mg} / \mathrm{kg}$ were capable of reducing MAP signiflcantly. Only at the highest dose of $30 \mathrm{mg} / \mathrm{kg}$, reglonal hemodynamic changes resembled those of CGP 18 137A. In doses of 1.010 mg/kg CGP 22979 A induced renal wasodilation without reducing $M R$ and 
HQR. After $30 \mathrm{mg} / \mathrm{kg}$, however, all reslstances decreased. Probably, this resulted from excessive release of CGP 18 . $137 \mathrm{~A}$ from the kidney plling over Into the circulation.

Renal vasodllators have a potential importance for clinical use in disease states such as hypertension and renal fallure. In the latter case, an increased renal resistance prevents normal glomerular filtration and the advantage of renal vasodilation may be a decrease In renal resistance without a concomitant fall in blood pressure that would further deterlorate renal function (Ackermann et al, 1982). Therefore, we studled the consequences of preferential renal vasodilation on renal hemodynamics and water and sodlum excretion.

After bolus injections, CGP 22 979A Increased ERPF dose-dependently, whereas CGP $18137 \mathrm{~A}$ caused a slight reduction. These observations conflrm our findings in the regional hemodynamic study where we used $20 \mathrm{MHz}$ pulsed Doppler probes to measure changes in renal blood flow after both compounds. The reduction of ERPF after CGP 18 137A was. assoctated with a fall in GFR, whereas this parameter did not change within the first $1.5 \mathrm{~h}$ perlod after CGP $22979 \mathrm{~A}$. In a previous study $\mathbb{1 n}$ anesthetlzed rats, Hofbauer et al (1985) noted a transient increase in GFR during the first $30 \mathrm{~min}$ after $10 \mathrm{mg} / \mathrm{kg}$ of CGP $22979 \mathrm{~A}$. The reason for the discrepancy between results from the two studies may derive from the anesthetlc used in one study, or from methodological differences. With regard to the effect of anesthesia, a dissoctation between effects in consclous and anesthetized antmals with regard to renal function has been reported for intrarenally administered acetylcholine and papaverine (Blaine, 1978; Blaine and Dunlay, 1981) although In the latter studles, GFR was affected stmilarly in conscious and anesthetized sheep. Alternatively, the differences may result from the different methods used, as the technique we used for the quantitation of GFR results in an integrated GFR value over a $1.5 \mathrm{hr}$ perlod (Sints et al, 1982). Thus, translent changes will not be detected. However, ERPF also represents an integrated value over the same period. Therefore, it may be concluded that there is a dissociation between effects on GFR and plasma flow. This suggests that CGP $22979 \mathrm{~A}$ causes both afferent and efferent arteriolar dilatation in the kidney. Posstbly, also the glomerular capillary filtration coefficlent may be 
reduced. On this basis, one would expect that the teduction in blood pressure that occurs after $30 \mathrm{mg} / \mathrm{kg}$ of CGP $22979 \mathrm{~A}$ would result in a decrease of GFR. However, our results suggest that the concontant increase in renal blood flow compensates for the fall in glomerular capillary pressure because GFR in rats depends both upon arterial pressure (filtration pressure) and blood flow through the glomerulus (Marchand and kohrman, 1980). After CGP 18 137A ERPF does not increase and, in fact, a fall in GFR is abserved which confirms this hypothesis.

At 3 to $4.5 \mathrm{hr}$ after CGP $22979 \mathrm{~A}$, the flow increases did no longer persist. At this time, however, MAP had fallen in the groups injected with 10 and $30 \mathrm{mg} / \mathrm{kg}$. Agailn, probably as a resultant of these two phenomena, GFR was reduced.

In spite of the unchanged GFR, a strong increase in water and sodium excretion was noted during the first 2 hr after CGP 22 979A. The increase in $\mathrm{V}$ and $\mathrm{U}_{\mathrm{Na}} \mathrm{V}$ confirms earliter observations $1 \mathrm{n}$ conscious normotensive rats (Hofbauer et al, 1.985). Although data on GFR and renal excretory function in the present study were obtalned in separate groups of animals and thus do not allow calculation of $\mathrm{FE}_{\mathrm{Na}}$ " the combined observations suggest a 2- to 4-fold increase in $\mathrm{FE}$ Na after CGP 22 979A. Such an increase in $\mathrm{FE}_{\mathrm{Na}}$ without changes in GFR as observed in the present study has been reported before and during renal vasodilatation by intrarenal infusions of substances like acetylcholine (Early and Friedler, 1965; W1111s et a1, 1968; Marchand et a1, 1977; Blaine and Dunlay, 1981), papaverine (Blaine, 1978; Blaine and Dunlay, 1981) and several prostaglandins (Strandhoy et al, 1974; 011ver et al, 1979). Several mechanisms have been put forward to explain the decreased fractional sodiun reabsorption. These include a washout of the juxtamedullary sodium gradlent (Early and Frledler, 1965), an lncrease in peritubular capillary pressure (Strandhoy et al, 1974) and an tncreased renal interstitial pressure (Marchand et al, 1977). Our study was not designed in a way to discriminate between these possible mechanisms.

The present study shows that in consclous SHR, CGP $22979 \mathrm{~A}$ is a preferential renal vasodilator. Computer stmulation studies of selective renal vasodilators suggest a more pronounced reduction in blood 
pressure during long-term treatment induced by a slow reduction in TPR wthout a change in plasma anglotensin II levels (struyker Boudier, 1980). The long-term regional hemodynanic studies showed that in the case of CGP $22979 \mathrm{~A}$ the acute preferential rena1 vasodilation developed Into a long-term selective renal and mesenteric rasodilation. A long-tern treatment of CGP 18 137A did not change the acute non-selective reglonal proflle. It is unllkely that vasodilation in the merentery during long-term CGP 22 979A treatment was induced by a sp111-over of CGP 18 137A from the kidney into the clrculation because such a splll-over would lead to a general vasodilation. We did not observe a wasodilation in the hindquarter vascular bed as was the case during long-tern CGP 18 137A treatment.

Orlowsky et al (1980) observed an accumulation and metabollism of N-acyl-y-glutamyl derivatives (CGP 22 979A like substances) preferentlally in the kldney, but also in other organs e.g. pancreas, small intestine, liver and spleen. So, a possible explanation for the mesenteric vasodflation could be that long-term CGP $22979 \mathrm{~A}$ treatment leads to a preferential renal accumulation of the active compound CGP 18 $137 \mathrm{~A}$ directly followed by accumulation of CGP $18137 \mathrm{~A}$ in the splanchnic wascular bed formed by the same but slower mechanism as in the kidney but Easter than in other tissue. Because no mesenteric vasodilation was seen after bolus injections of CGP $22979 \mathrm{~A}$, this accumulation process has to be Independent of plasma CGP 22 979A concentration. Measurements of plasma and tissue concentrations of CGP $22979 \mathrm{~A}$ and CGP 18 137A will be necessary to confirm this hypothesis.

In the treatrent of hypertension, renal vasodilation may trigger a sequence of events that witimately results in a decreased total peripheral reststance as a reflection of renal vasodilation and autoregulation of other vascular beds. Autoregulation in this context means that the individual tissues have an intrinsic ablitty to regulate thelr perfusion through changes in vascular resistance. Another posible explanation for the mesenteric vasodilation during long-term CGP 22 979A treatment could be autoregulation because no flow changes were observed in that vascular bed. Th1s phenomenon was not seen in the hindquarters in spite of a significant flow decrease during a 5 -day infusion of CGP $22979 \mathrm{~A}$. In Iiterature, autoregulation of almost 
all vascular beds has been described extensively (reviews schalekamp et a1, 1985; Coleman et $a 1,1979$ ). Few studies, however, are avallable describing differences in capability between vascular beds to autoregulate in one individual. Autoregulation was investigated in several organs in one preparation by Liard (1981). He increased cardiac output in conscious dogs by salt-loading. These animals exhlblted on the first day of infusion a $25 \%$ increase of arterlal pressure and cardiac output. Blood flows to the kidney and the splanchnic area were not significantly changed whereas skeletal nuscle blood flow almost doubled. After several days, cardiac output returned towards control values but blood pressure remained elevated. Skeletal muscle blood flow as most other regional flows did not differ significantly from control values. These data lndicate that the renal and mesenteric vascular beds immediately autoregulate by flow changes whereas the skeletal muscle vascular bed needs several days to autoregulate flow to control values. Our long-term observations correlate these previous findings.

Preliminary studies indicated that long-term administration of CGP 22 979A in SHR indeed leads to a chrontc reduction in blood pressure (Smits et al, 1984). The present long-term regional hemodynanic studies confirm these observations. A slow continuous reduction in blood pressure was observed during long-term CGP 22 979A infuslon with the advantage of no change in heart rate. Thts in contrast to the rapid sustalned fall in blood pressure and tachycardia during CGP 18 $137 \mathrm{~A}$ administration. The long duration of tachycardia polnts to a lack of adaptation of the baroceflex to the prevalling levels of blood pressure. It has been shown in chapter 4 that the tachycardia after bydralazine is medlated through stno-aortc baroreceptors in SHR. Moreover, It was shown in chapter 4 that the activity of the baroreflex was only of very short duration, $v i z \cdot 1-2 \mathrm{hr}$, whereas the fall in blood pressure may last up to 6-8 hr after a stngle dose of hydralazine. An explanation for these observattons could be that hydralazine and hydralazlne-1 lke substances directly stimulate baroreflex mechanisms. In the case of a bolus injection, the plasma drug level after 1-3 hr was possibly too low for a plasma concentration dependent direct effect on baroreceptor reflex, whereas durling chrontc infuston, 
plasma levels were suffictently high enough. Plasma measurements will be necessary to confirm this hypothesis.

Another difference of CGP 22 979A treatment over the hydralazine-1lke vasodilator CGP 18 137A was its effect on plasma renin concentration. In contrast to the increase in PRC during CGP 18 137A treatment, wo change was observed in the case of CGP $22979 \mathrm{~A}$. The increase of renin during treatment wh non-selective vasodilators is thought to result primarily from reduced renal perfuston pressure and a baroreflex medlated Increase of sympathetic nerwous activity (Gross, 1977). A baroreflex activation was not observed durling the long-term CGP 22 979A treatment. Furthemore, it is unlikely that renal perfuston pressure decreased during the first period of CGP 22 979A infusion because systemlc blood pressure decreased only to a small extent. With regard to the baroceflex and remal perfusion pressure, it is not surprtsing that PRC did not increase in the case of CGP $22979 \mathrm{~A}$. Plasma renta release, however, a1so. increases as a consequence of sodium depletion (Tarazi et al, 1970; Vaughan et al, 1973; Vaughan et a1, 1978). This sodium depletion lirits the long-term use of diuretic agents in the treatment of hypertension. In spite of the increase in sodium and water excretion during CGP $22979 \mathrm{~A}$ treatment, plasma renin activity did not increase. Possibly, tubular contents and transmural pressure in renal arterioles were in such a balance that renin release was not influenced in the kidney.

In conclusion, CGP $22979 \mathrm{~A}$ is a prodrug for the hydralazine-1ike vasodilator CGP $18137 \mathrm{~A}$. Low doses (up to $10 \mathrm{mg} / \mathrm{kg}$ ) have no immediate effect on blood pressure, whereas $30 \mathrm{mg} / \mathrm{kg}$ causes a fall in blood pressure as does CGP 18 137A. Contrary to the active compound CGP 18 $137 \mathrm{~A}$, the renal vasodilator prodrug CGP $22979 \mathrm{~A}$ causes acute rises in renal blood flow and water and sodlum excretion in spite of an unchanged GFR. The nature of the central hemodynamic changes for the active compound and the prodrug are different in as much that the actlve compound CGP $18137 \mathrm{~A}$ immediately reduces TPR and increases CO, whereas the prodrug gradually decreases peripheral reslstance and causes less Increase in $\mathrm{CO}$, posstbly due to the concomitant diuretic effect. In contrast to the long-tern CGP $18137 \mathrm{~A}$ treatment, no tachycardia and plasma renin activity increase were observed in the case of 
CGP 22 979A. The acute preferential renal vasodilation changed to a renal and mesenteric vasodilation. These results suggest that selective renal vasodilators may offer an important advantage to hydralazine-Ilke vasodilators in the long-term treatment of hypertension. 

CHAPTER 8

CONCLUDING REMARKS

In this thesis, the central and regional hemodynamic actions of several antihypertenslve drugs were linvestigated in consclous anrestralned SHR. For the central hemodynanic measurements, rats were chronically instrumented with electromagnetic flowprobes and for the regional herodynamics, mialaturized Doppler flowprobes were implanted. In the different chapters of this thesis the usefulness of these models to study hemodynamics was shown. The major advantage of these animal models is that they allow the continuous characterization of hemodynamic effects of antihypertensive drugs in undisturbed unanesthetized hypertensive small animals.

The acute central hemodyomic studies showed that the vasodilatars hydralazine, dihydralazine, endralazine, CGP $18137 \mathrm{~A}$ and the calcium entry blockers verapam11, nffedipine and PY 108-068 decrease total peripheral resistance and induce a baroreflex medlated increase in cardiac output. This in contrast to the effects of both beta-adrenoceptor blockers propranolol and tertatolol. The latter substances decrease cardiac output and cause a baroreflex medlated increase in total perlpheral resistance. In the case of beta-blockade the baroreflex mechanism can compensate the reduced cardiac output by a vasoconstriction. In the case of the vasodilators, the baroreflex mechanism is not able to completely compensate the reduced vascular resistance by the increase in cardlac output. Furthermore, the reglonal. hemodynamic studies show that the baroreflex also plays an important role in the regional specificity of some vasodilators.

In these regional hemodynamic studies, flow changes were mea sured through the kidney, mesentery and skeletal muscle of the hind- 
quarters of the rat. These three vascular beds recefve about $60 \%$ of the total cardiac output.

The reglonal hemodynamic studles showed that hydralazine and the hydralazine-like substance CGP 18 137A cause a general vasodilation in all three vascular beds measured. This was not observed for the calclum entry blockers. These substances reduce hindquarter vascular resistance but do not affect renal and mesenterlc resistance. In the central hemodynamlc studies following $C E B s$, the reduction in total peripheral resistance was greater than the fall in hindquarter resistance. So, it is likely that the calclum entry blockers nifedipine, verapamil and PY 108-068 also dilate other vascular beds not included in our measurements.

In sino-aortic baroreceptor denerwated animals the regional dilatory pattern was almost similar to that in intact animals after hydralazine. The calcium entry blockers showed after demervation at a 10-fold lower dose, a general vasodllatation in all three vascular beds. These results suggest that the baroreflex mechanism plays an inportant role in the short-term reglonal speciflcity of calctum entry blockers but not in that of hydrallazlne and $\operatorname{CGP} 18137 \mathrm{~A}$.

Baroreceptor reflex activation by unilateral common carotid acclusion increases resistance in renal, hindquarter and mesenterlc vascular bed. These results Indicate that the reglonal specificity of calctum entry blockers cannot be explained by a different degree in sympathetic Innervation of the vascular beds. Alternatively, a selective blockade of the sympathetic influence on skeletal muscle and posstbly other, not measured, vascular beds may play a role.

A selective reduction of the sympathetic influence on vascular beds mallso underly the reglonal spectficity of the non-selective beta-blockers propranolol and tertatolol used in this thesis. Propranolol causes a comparable early increase in vascular reststance in the renal, hindquarter and mesenterlic bed. Tertatolol, however, causes an early increase only in indquarter resistance. In the central hemodynamic studies, a more pronounced early increase In total peripheral resistance was observed in the case of tertatolol as compared to propranolol suggesting involvement of other vascular beds.

After removal of the simo-aortic baroreceptor reflex control, 
both beta-blockers behave similarly. A reduction in renal, an increase in hindquarter and no effect on mesenteric resistance was observed at a similar blood pressure reduction. These studies suggest that the regional specificity of tertatolol can be explained by a selective blockade of the sympathetic influence on the renal and mesenteric vascular beds but not on the hindquarter. Furthermore, these studies indlcate that tertatolol increases a baroreflex mediated vasoconstriction in several not measured vascular beds, or that propranolol decreases or blocks a baroreflex mediated vasoconstriction in the other beds.

It may be assumed that the influence of a baroreflex-mediated Interference with the hemodynamic effects of an antihypertensive drug disappears gradually, since it is known that the baroreceptor reflex resets to the prevailing blood pressure after a certain anount of time. So, during long-term treatment, the reglonal hemodynamic effect of the different antihypertensive drugs should be simllar to those measured in stno-aortic baroreceptor denervated anlinals if no other reflexes are involved. For the vasodilators used in the studies described in this thesis, the reglonal hemadynamic effects in sino-aortic denervated animals were almost similar to the ones measured during long-term treatment. However, by comparing the acute and long-term reglonal hemodynamic studies of both beta-blockers propranolol and tertatolol, it seems that there is a difference in baroreceptor resetting in time. The long-term reglonal pattern of propranolol is almost comparable with that measured in intact anlmals after a bolus injecthon. However, the long-term reglonal pattern of tertatolol is almost similar as the pattern measured in the sinom aortic baroreceptor denervated anlmals. These observations suggest a more rapld resetting in the case of tertatolol and hardly any resetting in the case of propranolol.

Computer sinulation studies hypothetlzed that renal vasodilation may trigger a sequence of events that ultimately results in a decreased total peripheral resistance as a reflection of renal vasodilation and autoregulation of other vascular beds. This hypothesis $1 \mathrm{~s}$ based on the natriuretic and diuretic effects of renal vasodilation. 
Our renal excretory function studies presented in chapter 7 confirm a duretic and natriuretic effect for the preferential renal vasadilator CGP 22 979A. Because glomerular filtration rate did not change after CGP 22979 we may assume that the natriuretic effect of this substance 18 a consequence of an increased tubular pressure.

The computer simulation study also suggests that selective renal vagodllation may have several great advantages above duretics in the treatment of hypertension. A longer therapy with diuretics leads, amongst others, to an increase in plasma renin activity but in the case of a renal vasodilation such a side-effect may not occur. Our long-term plasma renin concentration studies showed indeed that CGP 22 $979 \mathrm{~A}$ does not change plasma renin concentration. This is in contrast to the effect of 1 ts parent compound that increased plasma renin concentration.

Different mechanlsms were suggested for the mesenteric vasodilation seen together with the renal vasodilation during long-term GGP $22979 \mathrm{~A}$ treatment. One possibility is that the mesenteric vasodilation is a consequence of autoregulation. However, another possible explanation for the mesenteric vasodilation could be that long-term CGP 22 979A treatment leads to a preferential renal accumulation of the active compound directly followed by accumulation of CGP $18137 \mathrm{~A}$ in the mesenteric vascular bed formed by the same but slower mechanism as In the kidney but faster than in other tissue. Measurements of plasma and tissue concentrations of CGP $22 \quad 979 \mathrm{~A}$ and CGP 18 137A w111 be necessary to exclude one of the possibilities.

The studles presented in this thesis show that hydralazine and hydralazine-like substances and calclum entry blockers are non-selective vasodilators with several side-effects. Some of these unwanted effects can be explatned by thelr non-selective action, e.g . headache, flushes, and obstipation. These observations indicate that an antihypertensive drug with a more selective site of action may offer great advantage in the treatment of hypertension. The data presented in this thesis on the selective renal vasodilator CGP $22979 \mathrm{~A}$ support this assumption. For this antihypertensive drug, a lack of slde-effects such as fluid retention, tachycardia and increase in plasma renin concentration, was observed. Furthermore, these data support the 
hypothesis underlying the computer simulation of the long-term anthypertensive properties of a selective renal vasodilation presented in chapter 1. These simulated effects of a preferential renal vasodilathon can be explained by reversing the hypothesis of Borst and Borstde Geus (1963) and Guyton (1974) for the development of hypertension. So far, the observed effects of the renal prodrug CGP $22979 \mathrm{~A}$ are in agreement with the simulation study. However, further Investiggtions of the acute and long-term effects of the renal prodrug on blood volume and extracellular fluid volume may lead to more evidence for the simulated hypothesis. 

SUMARY

Hypertension is one of the riskfactors for cardiovascular diseases. In the established phase of essentlal hypertenston the major hemodynamic change is an increase in total peripheral resistance. Several hypotheses which could explain this increase in total peripheral resistance are discussed in chapter 1 .

Nowadays many antihypertensive drugs with vartous mechanisms of action are avallable. The usefulness of these antihypertensive drugs is often 1 imlted as a consequence of several side-effects occurring during the use of these drugs in therapy. Some of these side-effects such as a reflex-mediated increase in sympathetic activity counteract the hemodynamic effects of vasodilators.

It has been suggested that the relative lack of side-effects of some antihypertensive drugs is related to differences in hemodynamic profile of action. Chapter 1 hypothesizes that a vasodilator with a preferential renal site of action may be an anthypertensive drug with a minimum of side-effects. A selective remal vasodilator may reverse a series of events thought to be responstble for the development of hypertension in the hypothesis of Borst and Borst-de Geus (1963) and Guyton (1974).

In the studies described in this thesis we have pald attention to the possible differences of several antihypertensive drugs with regard to their central and reglonal hemodynamic effects. Furthermore, in some cases also renal hemodynamics and excretory functions were studied.

Chapter 2 descrtbes the surgery and the methods used in the studies of this thesis. For the central hemodynamic measurements rats 
were chronically instrumented with electromagneth flowprobes and for the reglonal hemodynamic neasurements Doppler flowprobes were implanted. In the reglonal hemodynantc studies flow changes were measured through the kldney, the mesentery, and the hindquarter of the rat. In al1 studies measurements pere performed in undisturbed unanesthetized rats.

The baroreflex is an Important mechanlsm in the short-term control of the cardovascular system. Thus it may play an important role in the acute hemodynamic effects of antihypertensive drugs. Therefore, the effect of baroreceptor unloading on reglonal hemodynamics in consclous WKY rats was investigated as described in chapter 3 . The baroreceptors were unloaded in unilaterally denervated rats by contralateral comon carotid occlusion, thereby activating the baroreceptor reflex. The results indicate that baroreceptor unloading leads to a vasoconstriction in all vascular beds studied.

Chapter 4 describes the hemodynamlc effects of hydralaztne and some hydralazine-1tke arteriolar vasodilators dihydralazine and endralazine. These agents lead to an immediate fall in blood pressure caused by a fall in total pertpheral resistance. This is associated with a bacoreflex mediated increase in cardiac output and heart rate. Endralazine is silghtly more active than hydralazine. The reglonal henodynamic studtes indlcate that the fall in total peripheral resistance after hydralazine is caused by a generalized reduction of resistance in the renal, hindquarter and mesenteric vascular bed. Furthermore, these studies indicate that the general vasodilation seen after hydralazine is the result of an additive effect of a strong direct vasorelaxation by hydralazine and a vasoconstriction by baroreflex activation.

In chapter 5 hemodynamic effects of the calclum entry blackers verapaint1, nifedipine and PY 108-068 are described. All three agents cause a dose-dependent fall in blood pressure and total pertpheral resistance. The fall in blood pressure triggers a baroreflex mediated rlse in heart rate and cardiac output which is probably counteracted by direct cardiac effects in the case of verapamil. In intact animals the acute fall in total peripheral resistance is related primarily to a decrease in wascular resistance of the muscular bed. However, the 
calcium entry blockers cannot be regarded as selective dilators of this vascular bed since in baroreflex denervated SHR and during longterm treatment in intact SHR the degree of vasodilation was similar in all three vascular beds studied. No effect on plasma renin concentration was observed during chronlc verapamil treatment.

Chapter 6 describes the hemodynamic effects of the beta adrenoceptor blockers propranolol and tertatolol in conscious SHR. The central hemodynamic studies show that after tertatolol adminlstration the cardiac output decreases immediately whereas the change in MAP consists of an early rise followed by a later decrease. These data confirm previous reports from our laboratory on the time dependent effects of the beta adrenoceptor blocker propranolol. The early rise th MAP, however, was more pronounced in the case of tertatolol as compared to propranolol. Previous studies have shown that the lack of acute decrease in blood pressure is caused by a baroreflex medtated rise in total peripheral resistance. The reglonal hemodynamic studies show that propranolol causes similar increases in vascular resistances in the renal, hindquarter and mesenteric beds. Tertatolo1, in contrast, causes an early increase only in hindquarter resistance. After removal of the sino-aortic baroreflex control, propranolol and tertatolol Induce similar effects, $1 . e$. a reduction in renal, an Increase in hindquarter and no effect on mesenterlc resistance. These results Indicate that tertatolol reduces the baroreflex mediated constriction in the renal and mesenteric vascular beds in latact anlmals. For tertatolol the long-term reglonal pattern in intact animals is almost sinilar to the acute reglonal hemodynamic effects measured 1 in denervated animals. This is in contrast to propranolol of which the longterm hemodynamic effects are comparable with the acute reglonal hemo dynamic effects in intact animals. These results suggest a more rapid baroreceptor resetting during long-term treatment with tertatolol as compared to propranolol.

Tertatolol thus protects the kidney from a hypoperfusion as was observed for propranolal. This difference in renal perfusion could lead to differences in renal excretory function. Both beta-blockers, however, induce an acute diuresis and have no effect on glomerular filtration rate. These results suggest a beta-adrenoceptor mediated 
reduction in tubulat reabsorption. During long-terc treatment a reduction in plagma renin concentration was observed in the case of propranolol. Tettatolol, in contrast, did not affect plasma renin concentration.

In chapter 7 the hemodynamic effects of the renal vasodillator prodrug CGP 22 979A and Lts pareat compound CGP $18137 \mathrm{~A}$ are described. Sequentlal hydrolysis by acylase and glutamyl-transpeptidase of CGP 22 $979 \mathrm{~A}$ is needed in order to generate the hydralazine like vasodilator CGP $18137 \mathrm{~A}$. These reactions occur at a higher rate in the kidney than In other tissues (Orlowgkl et al, 1980), possibly resulting in a selective accumulation of the parent compound in the kidney.

Low doses of CGP $22979 \mathrm{~A}$ (up to $10 \mathrm{mg} / \mathrm{kg}$ ) have no inuediate effect on blood pressure, whereas $30 \mathrm{mg} / \mathrm{kg}$ causes a maximal fall in blood pressure comparable to the fall induced by CGP $18137 \mathrm{~A}$ ( $1 \mathrm{mg} /$ $\mathrm{kg}$ ). Contrary to the parent compound CGP $18137 \mathrm{~A}$, the renal vasodilator prodrug CGP $22979 A$ causes acute rises in renal blood flow and water and sodtum excretion in spite of an unchanged GFR. The nature of the central hemodynantc changes for the active compound and the prodrug is different inaswuch as the active compound immediately reduces total peripheral resistance and increases cardiac output, whereas the prodrug gradually decreases peripheral resistance and causes a smaller Increase in cardiac output, possibly due to the concomitant diuretic effects. In contrast to the effects observed during long-term CGP 18 137 A treatment, no tachycardia and no increase in plasta renin concentration are observed in the case of CGP 22 979A. The acute preferenthal renal vasodilation changes to renal and mesenteric vasodilation during long-term cop $22979 \mathrm{~A}$ treatment.

In chapter 8 the implications of the different regional hemodynamlc proftles of antihypertensive drugs are discussed in relation to the long-term treatment of hypertensive disease.

The lack of the side-effects induced by vasodilators, 1 .e. fluid retention, tachycardia and increase in plasma renin concentration, may offer great adwantage for a selective renal vasodllator in the treatment of hypertension. 


\section{SAMENUATTING}

Hoge bloeddruk is een risikofaktor voor hart- en vaatzlekten. De belangrijkste hemodynamische verandering in de gestablliseerde fase van essentiele hypertensie is de toegenomen totale perifere weerstand. Verschillende hypothesen die deze toename in totale perifere weerstand zouden kunnen verklaren, zijn beschreven in hoofdstuk 1 .

Tegenwoordig is een groot aantal bloeddrukverlagende niddelen met een verschillend werkingsmechanfsme beschikbaar. Door diverse bijwerkingen is de bruikbaarheld van deze anthypertensiva vaak beperkt. Sormlge van deze bijwerkingen, zoals de reflex gemedleerde toename in sympathische zenuwaktiviteit en de renale retentle van zout- en water, werken het hemodynamische effekt van antihypertensiva tegen.

Er wordt wel gesuggereerd dat het uttblijven van ongewenste effekten van sommige anthypertenslva samen hangt met een verschillend hemodynamisch werkingsprofiel. Hoofdstuk 1 bespreekt onder andere de hypothese dat een vatuerwijder met een bij voorkeur renal aangrijpingspunt mogelifk minimale bijwerkingen heeft. Een selektleve renale vaatverwiljer keert mogelifk de volgorde van de gebeurtenlssen die verantwoordelfjk $z \mathbb{1}$ jn voor het ontstaan van hoge bloeddruk volgens de hypothese van Borst en Borst-de Geus (1963) en Guyton (1974) on.

In de studies beschreven in dit proefachrlft werd andacht be steed aan mogelijke verschllien van diverse antihypertensiva met betrekking tot hun centrale en regionale hemodymantsche effekten. Werder werd in enkele gevallen ook de renale hemodynamika en zout- en wateruitscheiding bestudeerd.

Hoofdstuk 2 beschrifft de chlrargle en methoden die gevolgd werden in de studies van dit proefschrift. Voor de centrale hemodyna- 
wibche wagen werden ratten chronisch geinstrumenteerd met elektromagnetische flowprobes en voor de regionale hemodynamische metingen met Doppler flowprobes. In de reglonale hemodynamische studies werden flowveranderlngen gemeten door de nier, het splanchnische vatued en het achter11jf yan de rat. In alle studies werden de metingen verricht in wakkere, vrij bewegende ratten.

De baroreceptorreflex is een belangrijk mechanisme voor de kontrole op korte termijn van het kardiowaskulaire systeem. Dientengevolge zou deze reflex mogelijk een belangrijke rol kunnen spelen in de akute hemodynamische effekten van anthypertensiva. Daarom werd het effekt van aktivatie van de baroreceptorreflex op de reglonale hemodynamika in wakere Wistar-Kyoto ratten bestudeerd, zoals beschreven in hoofdstuk 3. In unilateraal gedenerveerde ratten werd door een kontralaterale okklusie van de arteria carotis de baroreflex geaktiveerd. De resultaten laten zien dat een ontlading van baroreceptoren tot een vasokonstriktie in alle bestudeerde vaatbedden leidt.

Hoofdstuk 4 beschrijft de hemodynamische effekten van hydralazthe en enkele hydralazine-achtige arteriolaice vaatverwijders, dihydralazine en endralazine. Deze stoffen veroorzaken een onmiddellijke bloeddrukdaling door een afname van de totale perifere weerstand. Dit gaat samen met een baroreflex gemedleerde toename van het hartminuutvolume en hartfrekwentie. Endralazine is wat aktiever dan hydralazine. De reglonale hemodynamische studles laten zlen dat de afname van de totale perifere weerstand na hydralazinetoediening bestaat uit een daling van de valatweerstand in de nier, het splanchnische gebied en het achterllff van de rat. Verder laten deze studles zten dat de algehele vaatverwljding na hydralazinetoedienlng het resultaat is van een sterke, direkt door hydralizhne veroorzakte vaatverwijding en een bicoreflex gemedleerde valuernawing *

In hoofdstuk $5 \mathrm{z} 1 \mathrm{jn}$ de hemodynamische effekten van de calciuminfluxremmers verapantl, nlfediplne en PY 108-068 beschreven. De drie substanties veroorzaken een dosisafhankelljke daling van de bloeddruk en totale perffere weerstand. De bloeddrukdaling leidt tot een baroreceptorteflex gemedieerde toename in hartfrekwentie en hartminutvolume. Deze toename wordt in thet geval van verapamil mogelijk tegengewerkt door een direkt effekt van deze stof op het hart. In intakte 
dieren is de akute daling van de totale perifere weerstand drekt gerelateerd aan een daling van de weerstand in het splervatbed. In de baroreceptor gedenerveerde spontaan hypertensieve ratten en tifdens de chronische toediening van calctuminfluexremmers wordt echter een vergelijkbare vaatverwijding wargenomen in alle drie de bestudeerde vatbedden. De calcluminfluxremmers kunnen dus niet als selektieve vaatverwijders voor het spiervaatbed beschouwd worden. Gedurende chronische verapamilbehandeling is geen effekt op de plasma reninekoncentratie waargenomen.

Hoofdstuk 6 beschrijft de hemodynamische effekten van de betablokkers propranolol en tertatolol in wakkere spontaan hypertensieve ratten. De centrale hemodynamische studles laten zlen dat na tertatololtoediening het hartminuutvolume onmiddellijk daalt, terwill de bloedrukverandering bestaat uit een akute toemame gevolgd door een daling. Deze gegevens komen overeen met de resultaten van eerder door ons laboratorium gepubliceerde studies met betrekking tot de tifdsafhankelljke effekten van de betablokker propranolol. De akute bloeddruktoename is echter meer uitgesproken in het geval van tertatolol ten opzichte van propranolol. Eerder gepubliceeerde studies hebben laten zien dat het ultblifven van een akute daling van de bloeddruk het gevolg is van een baroreflex gemedieerde toename in totale perifere weerstand. De reglonale hemodynamische studles laten zien dat propranolol een vergelijkbare toename ta vaatweerstand veroorzaakt in de nier, het splanchnlsche gebied en achterlijf van de rat. Tertatolol daarentegen veroorzakt slechts een toename van de valweerstand in het achterliff. Na het wegnemen van de baroreceptorreflex veroorzaken tertatolol en propranolol vergelijkbare effekten, namelijk een vermindering in renale vatweerstand, geen effekt in splanchnische valatweerstand en een verhoging van de weerstand in het achterliff. Deze resultaten leiden tot de konklusle dat tertatolol de baroreflex genedieerde vasokonstrlktie afzwakt in de nler en het splanchnlsche gebied van intakte dieren. Voor tertatolol is het reglonale patroon in intakte dieren op lange termijn vrijwel vergelijkbaar met de akute reglonale hemodynamische effekten gemeten in gedenerveerde dieren. Dit in tegenstelling tot propranolol, waarvan de lange termifn hemodynamlsche effekten beter vergelijkbaar $z i j n$ met de akute reglonale hemodyna- 
minche ffekten la intakte dieren. Deze resultaten suggereren voor tertatolol een snellere baroreceptor reseting gedurende lange termijn behandeling dan voor propranolol.

Tertatolol bescherrat dus de nier voor een verminderde perfusle, zoals de was wargenomen voor propranolol. Een dergelijk verschil in renale perfugle zou tot verschillen in renale water- en zoutultscheiding kunnen lelden. Dit 1 echter alet gewonden. Beide betablokkers veroorzaken namel jkk een akute diurese en hebben geen effekt op de glomerulatre filtratlesnelheid. Deze resultaten suggereren een betaadrenoceptor genedieerde vernindering in tubulaire reabsorptie. Gedurende de lange termijn behandeling met propranolol werd een daling van de plasma reninekoncentratie wargenomen. Tertatolol daarentegen heeft geen invloed op de plasma renfnekoncentratie.

In hoofdstuk $7 \mathrm{zljn}$ de hemodynamische effekten wan de renale prodrug CGP 22 979A en zijn aktleve werbinding CGP 18 137A beschreven. Gedeeltel1jke hydrolyse van CGP $22979 \mathrm{~A}$ door acylase en glutamyltranspeptldase is nodig om de hydralazine-achtige vaatverwijder CGP 18 137A te genereren. Deze reakties verlopen sneller in de nier dan fin ander weefsel (Orlawskl et al, 1980) wat mogelljk een akkumulatile van de actleve verbinding in de nier tot gevolg heeft. Lage doseringen CGP 22 979A (cot $10 \mathrm{mg} / \mathrm{kg}$ ) hebben geen onniddellijk effekt op de bloeddruk, terw1 $1130 \mathrm{mg} / \mathrm{kg}$ een daling van de bloeddruk veroorzalkt vergelijkbaar met de daling geinduceerd door CGP $18137 \mathrm{~A}$ (1 $\mathrm{mg} / \mathrm{kg}$ ). In tegenstelling tot de aktieve verbinding CGP 18 137A veroorzaakt de renale produrg CGP 22979 A een akute toemame van de renale doorbloeding em water- en zoutuftscheiding bif een onveranderde glomerulaire filtratlesnelheid.

De centrale hemodynamische veranderingen voor de aktieve verbinding en de prodrug zijn in zoverre verschillend dat de aktleve verbinding onmiddellijk de totale perifere weerstand doet dalen en het hartminuutvolume doet ste 1 ggen, terwifl de prodrug langzaam de totale perifere weerstand doet dalen en een klefne toename in hartminuutvolume veroorzakt, mogelifk als gevolg van het hlerboven beschreven diuretisch effekt. In tegenstelling tot de effekten waargenomen gedurende de lange termijn CGP 18 137A behandeling is in het geval van CGP 22 979A geen tachykardle en geen toename in plasma renine-aktiviteit waargenonen. Terwifl in de akute experimenten de vaatverwijding prefe- 
rentieel renaal is, wordt bif de chronlsche behandeling met CGP 22 9794 een renale en splanchnische vatuentjding gezien.

In hootdstuk 8 zijn de implikatles van de verschillende reglonale proflelen van de antihypertenstua beschreven in relatle tot de lange termign behandeling van hoge bloeddruk.

Doordat bij selektieve renale vatuerwljding bijwerkingen, zoals vochtretentie, tachykardie en een toename in plasma reninekoncentratie, uitblijven, biedt deze groep van watuerwijders mogelijk grote voordelen bij de behandeling van hoge bloeddruk. 



\section{REFERENCES}

Abboud FM. Hypertension 4 (supp1 2), 208, 1982.

Abe $Y$, Komor $1 \mathrm{~T}$, Muira $\mathrm{k}$, Takada $\mathrm{T}$, Imanishi $\mathrm{M}$, Okahana $T$, Yamamoto $\mathrm{K}$. J Cardiovasc Pharmacol 5, 254, 1986.

Ackerman DM, Blumberg AM, McCafferty JP, Sherman SS, Weinstock J, Kaiser C, Berkawitz B. Fed Proc 42, 186, 1983.

Ackerman DM, Wefinstack J, Wiebelhaus VG, Berkowitz B. Drug Dev Res 2, $283,1982$.

Ackerman DM Woodward P. Fed Proc 42, 748, 1983.

Alexander $N$, DeQuatero W. Circ Res 35, 636, 1974.

Arendshorst WJ, Johnston PA, Selkurt EE. Am J Physiol 226, 218-225, 1974.

Baer PG, McGiff JC. Eur J Pharmacol 54, 359, 1979.

Barron KW, Faber JE, Lappe RW, Trapant AJ, Brody MJ. Fed Proc 24, $1085,1983$.

Beasly D, Malvin RL. Proc Soc Exp Blol Med 178, 575, 1985.

Be11o-Reus E. Am J Physio1 238, F347, 1980.

Bencsath P, Asztalos B, Szalay L, Takacs L. Am J Physiol 236, 513, 1979.

Berkowitz BA, Ohlstein EH. J Cardiovasc Pharmacol 6 (suppl), 559, 1984 .

Bernsteln KN, O'Connor DT. Annu Rev Pharmacol 24, 105, 198.4.

Besarab B, Silva P, Landsberg L, Epstein FH. An J Physilol 233, F39-, 1977.

Blanchi G, Fox U, Difrancesco G, Bardi U, Radice M. Eur J Clin Invest $3,213,1973$.

Bianchi G, Baer PG, Fox U, Guidi E. Postgrad Med J 53 (supp1 2), 123, 1977 .

Blaine EH. Proc Soc Exp Blol Med 158, 250, 1978.

Blaine EH, Dunlay MC. J Pharmacol Exp Ther 218, 470, 1981 .

Blaine EH, Russo HF, Schorn, TW, Snyder C. J Pharnacol Exp Ther 22, $152,1982$.

Blantz RC. Fed Proc 36, 2602, 1977.

Blaustein MP. Rev Physiol Pharmacol 70, 33, 1974.

Bohlen H. Hypertension 8, 181,1986 .

Bolt GR, Saxena PR. J Pharmacol Exp Ther 230, 205, 1984a.

Bolt GR, Saxena PR. J Cardlovasc Pharmacol 6, 707, $1984 \mathrm{~b}$.

Bond RF, Green HD. Am J Physiol 216, 393, 1969.

Borst JGG, Borst-de Geus A. The Lancet 1, 677, 1963.

Braunwald E, Ross J, Sonnenbllck EH. New Engl J Med 177, 962, 1967. 
Brennan $F$, Kavanagh $B$, Whebelhaus V. Fed Proc 42, 1133, 1983.

Brenner BM, Meyer TH, Hostetter TH. New Engl J Med 307, 652, 1982.

Britton KE, Gruenewald SM, Nmon CC. Proc Soc Med 37, 77, 1981.

Brunner HR, Jaeger $P$, Perguson $R K$, Jequier $E$, Tur 1 n $G$, Gavras $H$. Br Med $J 2,385,1978$.

Buckinghar RE, Hamilton T. Br J Pharmacal 68, 667, 1980.

Büler FR, Laragh JH, Baer $L$, Vaughan ED, Brunner HR. New Engl J Med $287,1209,1972$.

Buhlet FR, Burkart F, Lutold BE, Kung M, Marbet G, Pfirsterer M. Am J Cardio1 36, 653, 1975.

Caput 1 AP, Rossi F, Lampa E, Vacca C, Giordano L, Marmo E. Agressology $19,325,1978$.

Carey RM, Dacey RG, Jane JA, Winn HR, Ayers CR, Tyson GW. Hypertension $1,246,1979$.

Carrara MC, Baines AD. Can J Physiol Pharmaco1 54, 683, 1976.

Case DB, Wallace JM, Klein HJ, Weber MA, Sealey JE, Laragh JH. New Engl J Med 296, 641, 1977 .

Casson IF, Clayden DA, Cope GF, Lee MR. Clin Sct 65, 159, 1983.

Chalgnon M, Bellet $M$, Lucsko M, Rapoud C, Guedon J. J Cardiovasc pharmacol 8, 892, 1986.

Chan YL. J Pharmacol Exp Ther 215, 65, 1980.

Charlton JD, Baertachil AJ. Am J Physiol 242, H520, 1982.

Chelly JE, Doursout MF, Begano B, Tsao CC, Hartly CJ. J Pharmacol Exp Ther $238,665,1986$.

Chenteux-Gulcheney $\mathrm{P}$, Dausse JP, Meyer P, Schnltt H. Br J Pharmacol $63,177,1978$.

Cohen ML, Kurz KD. J Pharmacol Exp Ther 220, 63, 1982.

Cohen ML, Kurz KD, Schenck KW. J Pharmacol Exp Ther 226, 192, 1983.

Coleman TG, Samar RE, Murphy WR. Hypertension 1, 225, 1979.

Colfer HT, Cottler C, Siandez R, Julius S. Hypertension 6, 145, 1984.

Collindres RE, Gottschalk CW. Fed Proc 37, $1218,1978$.

Cox RH, Bagshaw RJ. Circ Res 37, 772, 1975.

Cox RH, Bagshaw RJ. Am J Physiol 237, H424, 1979.

Cox $\mathbb{R H}$, Bagshaw RJ. Effects of pulsations on carotid sinus control of reglonal arterial hemodynamics. Am J Physiol 238, H182, 1980.

Cregeen R.J, Rudge PJ, Mills J, Vincent S, Burland $W .2$ 2nd Eur Meeting on Hypertension, Mlan, abstr 115, 1985.

Damen M. Renal effects of infusion of atriopeptin II in conscious, unrestratned SHR, 1987. Submitted for publication.

Dahl LK, Herne M. Alostr Am Heart Assoc Connc for High Blood Pressure Research, 1973.

Danesh BJ, Brunton J. Proc Soc Med 37, 87, 1981 .

Danesh B.J Bruntton $J$, Simaner DJ. C1fin Sc1 67, 243, 1984.

Davy $M$, Middol-Monnet $M$, Cohen $Y$, Weplerre J. Arch Int Pharmacodyn $230,257,1977$.

De Blasi A, Lipartiti M, Garatini S. Am J Nephrol 6 (suppl 2), 69, 1986.

De Bruyn JHB, Man in 't Veld AJ, Wenting GJ, Derkx FHM, Schalekamp MADH. Eur J Clin pharaacol 20, 163, 1981.

De Leeuw PW, BH renháger WH. Hypertension 4, 125, 1982.

Derks FHM, Wenting GJ, Man in 't Veld AJ, Verhoeven RP, Schalekamp MADH. Clin Sci, 529, 1978.

De Wardener HE, MacGregor GA. J Chron Dis 34, 233, 1981.

De Wardener HE, Clarkson BM. Clin Sci 63, 415, 1983. 
DiBona GE. Am J Physiol 233, F73, 1977.

DiBona GF, Zambraski EJ, Aguilera AT, Kaloyanides GJ. Circ Res 40 (supp1 1), 127, 1977 .

DiBona GF. C11n Sei 54, 529, 1978.

DiBona GF, Sawin LL. Am J Physiol 243, F576, 1982.

Dietz JR, Davis Jo, Freedman RH, Villarreal D, Echtenkamp SF. Fed Proc $41,5615,1982$.

Diz DI, Nasjletti A, Bear PG. Hypertenston 4, 361, 1982 *

Drayer JIM, Weber MA, Longworth D1, Laragh JH. Am J Med 64, 187, 1978.

Drexler H, Flaim SF, Fields RM, Zelis R. I Pharmac Exp Ther 232, 376.

Drumer OH, Worland PUJ, Jarrott B. BLochem Pharmacol 32, 1563, 1983.

Early LE, Friedler RM. J Clin Invest 44, 1857, 1965.

Eggertsen R, Sivertsson R, Andrin L, Hansson L. J Hypert 2, 529,1984 .

Elliott HL, Mclea K, Summer DJ, Donnelly RJ, Reid JL. Clin. Exp Hypert $4 \mathrm{~A}, 1409,1982$.

Epstein M, Oster JR. Mi neral Ellectrol Metab 8, 237, 1982.

Evenwel RT, Kasbergen CM, Struyker Boudier HAJ. CIIn Exp Hypert A5, $1511,1983$.

Faden SZ, Hernandez-Liamas G, Patak RV, Rosenblatt SG. Lifschitz MD, Stein JH. J Clin Invest $69,604,1982$.

Fernandes $M$, Onesti G, Fiorentini R, Kin KE, Schwartz C. Life Sci 18 , $967,1976$.

Fernandes $M$, Onesti G, Fiarentini $R$, Gould AB, Kin KE, Schwartz C. Clin Scil Mol Med 52, 107, 1977 .

Fitzgerald JD. In: Handbook of hypertension. vol. 3 (ed: PA Van zwleten). Elsvier Publishing Company, Amsterdan, 1984, p 249.

Fitzgibbons JP, Gennari J, Garfinkel HB, Cortell S. J Clin Invest 54, 1428,1974 .

Flatm SF, Zelis R. J Pharmacol Exp Ther 222, 359, 1982.

Folkow B, Neil E. In: Circulation (ed. B. Folkow and E Nell), New York, Oxford University Press, 1971, pp 220.

Folkow B. Clin Sel Mol Med 55 (suppl 4), 3, 1978.

Eolkow B. Physiol Rev 62, 347, 1982.

Fouad F, Cetmo J, Tarazi R, Bravo E. Circulation 61, 163, 1980.

Furchgott RF, Zawadzk1 JV. Nature 286, 373, 1980.

Fyhrquist F, Soveri P, Puutula L, Stenran U. C1in Chem 22, 250, 1976.

Gavendo S, Kapuler S, Serban I, Iafna A, Ben-David E, Eliahou H. Kidney Int $17,764,1980$.

Gerber JG, Branch RA, NHes AS, Gerkens JF, Shand DG, Hollifleld J, dates JA. Prostaglandins $15,81,1978$.

Gerber JG, Nies AS. Circ Res 4.4, 406, 1979.

Goldberg LI, Volkman PH, Kohli JD. Ann Rev Pharmacol Toxicol 18, 57 , 1978.

Goldberg LI, Koh11 JD, Comm Psychopharmaco1 3, 447, 1979.

Goldberg LI, Kohli JD. Trends Pharmacol Sci 4, 64, 1983.

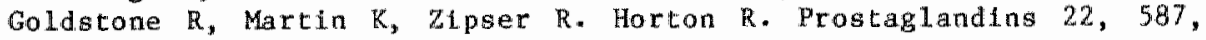
1981 .

Goto F, Fuyita T, Fuse Y. Br J Anaesthes101 51, 107, 1979.

Gottlieb TB, Katz FH, Chidsey CA. Circulation 45, $571,1972$.

Green HD, Rapela CE (eds). Shock and hypotenston. Grune and Stratton, New York, 1965, p 91.

Gross F. In: Antihypertensive drugs (ed: F Gross). Spinger Verlag, Berlin-Heidelberg-New York, 1977, p 397.

Gross JB, Bartter FC. Am J Physiol 225, 218, 1973* 
Gross F, Druey J, Heyer R. Experientia 7, 11, 1950.

Gross R, trchelm H, Olshausen K. Arzneim Forsch $29,1361,1979$.

Gruber KA. Whittaker MM, Buckalew M. Wature (Lond) $287,743,1980$.

Guazi M, Olivari MT, Polex A, Plorentini C, Magrinl F, Moruzzi M. Clin Pharmacol Ther 22, 528, 1977.

Gulat OP, Liard JF. Arch Int Pharmacodyn Ther 240, 285, 1979.

Gutkin $M, D a B$, Chin $B K$, Mezey $K$, Modlinger RS. J Clin Pharmacol 17 : $509,1977$.

Guyton AC. Am J Cardiol 8, 401, 1961.

Guyton AC, Coleman TG, Granger HJ. Ann Rev Physiol 34, 13, 1972.

Guyton AC, Coleman TG, Cowley AW Jr, Manning RD Jr, Norman RA Jr, Ferguson JD. Circ Res 35, 159, 1974.

Haas JA, Hammond TG, Granger JP, Blatne EH, Knox FG. Am J Physiol 247, F 475,1984 .

Haddy FJ, Pamnant MB, Clough D1. Life Sc1 24, $2105,1979$.

Haddy FJ, Pamnant MB. C1L Exp Hypert A7, 633, 1985.

Haeusler $G$, Gerold M. Naunyn Schmledeberg"s Arch Pharmacol 310, 155, 1979.

Hahn RA, Wardel1 JR, Saran HM, Ridley PT. J Pharmacol Exp Ther 223, $303,1982$.

Hanamer $J$, U1rych M, Erels ED. Clin Pharmacol Ther 12, 78, 1971.

Hares $P$, James IM, Griffith D. Br J Clin Pharaaco 1 4, 373, 1977.

Harron DWG, Kobinger W, Lillie C. Eur J Pharmacol 104, 71, 1984.

Hartling $0 J$, Lysbo-Swendsen T, Trap-Jensen J. Clin Sci. 60, 675, 1981.

Hartupee DA, Burnett JC, Mertz JI, Knox FG. Am J Physio1 243, E325-, 1982 .

Hatzinikolaou P, Charocopos F, Gavras I, Gavras H. Cl in Exp Hypert A $5,729,1983$.

Haywood JR, Shaffer RA, Fastenow C, FInk GD, Brody MJ. Am J Physiol $241,4273,1981$.

Heesch CM, Miller BM, Thames MD, Abboud FM. Am J Physiol 245, H653, 1983.

Henrlch $H$, Hertel $R$, Assmann $R$. Pflügers Arch 375, 153, 1978 .

Higuch1 S, Takeshita A, Ito $\mathbb{N}$, Imalzumi $T$, Matsuguchi $H$, Nakamura $M$. Circ Res 57, 245, 1985.

Hockel GM, Cowley AN. Am I Physiol 237, H449, 1979.

Hof RP. Br J Pharmacol 78, 375, 1983.

Hof: RP, Hof $A$, Neumann P. J Cardlovasc Pharnacol 4, 352, 1982.

Hofbauer KG, Sonnenburg C, Stalder R, Criscione L, Kraetz J, Fuhrer W. J Pharmacol Exp Ther 232, 838, 1985.

Hollenberg NK. Clin Pharnacol 7 (supp1 2), $219,1979$.

Hollenberg NK. Am I Cardiol 49, 1425, 1982 .

Ho Pak C, Matsunaga $M$, Yamamoto $J$, Kira J, Ogino $K$, Kawal C. Jpn Heart $J 18,392,1977$.

Hornych A, Safar M. Am J Cardiol 49, 1524, 1982.

Huot S.J, Pamnani MB, Clough DL, Buggy $J$, Brayand $H J$, Harder DR, Haddy FJ. Hypertenstion 5 (suppl 1), 94, 1983.

Hutchins PM, Darnel1 AE. Circ Res 34 (suppl 1), 161, 1974.

Imagawa $J$, Kurosawa $A$, Satoh S. J Cardiovase Pharmacol 8, 636, 1986.

Imanisht $M$, Abe $X$, Okahara $T$, Yuktmura $T$, Yamamoto K. Jpn Circ J 44, 875,1980 .

Ish11 H, Itoh K, Nose T. Eur J Pharmacol 64, 21, 1980.

Jandhyala BS, Ausart AF. Clin Sci (in press), 1987.

Janssen B. Fed Proc. In press, 1987. 
Johnson BF. Clin Pharmacol Ther 12, 815, 1971 .

Johnston CI, Newman M, Woods $\mathbb{R}$. Clin Sei 61 (suppl), 129, 1981 .

Johnston HH, Herzog JP, Lauer DP. An J Physiol 213, 939, 1967.

Johnston CI, Newman M, Woods R. Clin Sci 61 (suppl), 129, 1981 .

Kanda K, Flaim SE. J Pharmacol Exp Ther 228, $711,1984$.

Karlberg BE, Kagedal B, Tegler L, Tolagen K, Bergman B. Am J Cardiol $37,642,1976$.

Katholi RE, Naftilan AJ, Oparils S. Hypertension 2, 266, 1980.

Katholi RE, Winternitz SR, Oparil S. Hypertension 3, 404, 1981.

Katholi RE, Whitlow PL, Winternitz SR, Oparil S. Hypertension 4 (suppl 2), 166,1982 .

Kawabe KT, Watanabe TX, Shiono $K_{3}$ Sokabe H. Jpn lleart J 19, 886, 1978.

Khatri. I, Uemura $\mathbb{N}$, Notariga-Como $A$, Freis ED. Am J Cardiol 40, 38, 1977.

Khayal1 M, Gross F, Kreye WAW: I Phamacol Exp Ther 216, 390, 1981.

Klowski H, Bertel S, Erne P, Boll1 P, Hulthén UL, Ritz R, Bthler FR. Hypertension 5 (supp1 1), 70, 1983.

Kinch W, Exthelm T. J Cardlovasc Pharmacol 4, 562, 1982.

Kirchheim H. Arch Ges Physiol 306, 119, 1969.

Kirchheim $H$, Gross $\mathbb{R}$. Arch Ges Phystol 315, 159, 1970.

Kirchheim H, Gross R. Arch Ges Physio1. 327, 203, 1971.

Kleinjans JCS, Snits JFM, Kasbergen CM, Vervoort-Peters HTM, Struyker Boudier HAJ. Clin Sci 65, 111, 1983.

Kline $\mathbb{R L}$, Kelton PM, Mercer PF. Can J Physiol Pharmacal 56, 818, 1978.

Knight DR, Kirby DA, Vatner SF. Hypertension 7, 380, 1985.

Knox FG, Mertz JI, Burnett JC, Haramati A. Circ Res 52, 491, 1983.

Koch-Weser J. Arch Int Med 133, 1017, 1974.

Kotchen TA, Maull KI, Luke R, Rees D. J C11n Invest 54, 1279, 1974.

Krieger EM. Circ Res 15, 511, 1964.

Krleger EM. Am J Physiol 213, 139, 1967.

Langer SZ, Shepperson NB. Trens Pharmacol Sct 3, 440, 1982.

Lantz B, Paillard F, Mignon F, Beaufils M, Ardalllou R. 9th Int Congr Nephrology, Los Angeles, abstr 215A, 1984.

Lappe RW, Tadt JA, Wendt RL. The Pharmacolog1st 26, 272, 1984.

Lauble M, Schmitt H, Mouillé P, Cheymol G, Gilbert JC. Arch Int Pharmacodyn 201, 334, 1973.

Laubie M, Prost J-F, Rochat C. Am J Nephro1 6 (suppl 2), 20, 1986.

Lauger $\mathrm{SZ}$, Shepperson NB. I Cardiovasc Pharmaco1 4, 58, 1982.

Lazarus JM, Hampers CL, Merri11 IP. Arch Int Med 133, 1059, 1974.

Lederba11e Pedersen 0, Mikkelsen E, Jespersen LT. I Cardiovasc Pharmaco1 4 (supp1 3), 294, 1982 .

Leenen FHH, Ackerman EW. C1in Exp Pharmacol Phystol 3, 575, 1976.

Lehmann HV, Hochrein H, Witt E, MLes HW. Hypertenston 5 (supp1 2), 66, 1983.

Leier CV, Magorien RD, Desch CE. Circulation 63, 102, 1981.

Leonetti G, Sala C, Blanchini C, Terzoli L, Zanchetti A. J Clin Pharmacol $18,375,1980$.

Lever AF. J Hypert 4, 515, 1986.

Liard JF. Experientia 33, 339, 1977.

Liard JF. Am J Physiol 240, H361, 1981.

Lipe S, Moulds RF. J Pharmacol Exp Ther 217: 204, 1981.

Loutzenhiser $R$, Epstein $M$, Horton $C$, Souke $P$. J Pharmacol Exp Ther $232,382,1985$.

Maekawa K, Lian C, Tsul A, Chen BT, Kawashima S. Circulation 70, 908, 
1984.

Man $1 \mathrm{n}$ 't Veld $A J$, Wenting GJ, Boomstia $F$ et al. Br J Clin Pharmacol 9, $547,1980$.

Marchand GR, Det CE, Lang FC, Greger RF, Knox FG. All J Physiol 232, P1.47, 1977.

Marchand GR, Mohrman DE. Life Sc1 27, 2571, 1980.

Martinez-Maldonado M, Tsaparas $N$, Eknoyan $G$, Suhi WN. Am $J$ Physiol 222, 1147,1972 .

Martinu JA, Early LE. J Clin Invest 46, 1963, 1967.

McGiff JC, Spokes EG. In: Frontlers in hypertension research (eds: Laragh JH, Buthler FR, Seldin DW), Springer Verlag, New York, $1981, \mathrm{pp} 105$.

Mcleay RAB, Stallard TJ, Roberts AIMLT, Watson RDS, Littler WA. Circulation $67,1084,1983$.

Mertz JI, Haas JA, Berndt TJ, Burnett JE, Knox FG. Am J Physiol 247 , F82, 1984 .

Mimran A, Targhetta $\mathbb{R}$, Laroche $B$. Hypertension 2, 732, 1980.

Moss NG. ClIn Exp Hypert. In press, 1987.

Murphy MB, Scriven AI, Brown MJ, Causon R, Dollery CT. Eur J Clin Pharmaco1 23, 479, 1982.

Nakaya H, Schwartz A, Millard RW. Circ Res 52, 302, 1983.

Warchos AP, Gulati OP, Carretero OA. An Heart J 94, 81, 1977.

Niarchos AP, Laragh JH. Mod Conc Cardiovasc Dis 49, 43, 1980.

NLeg AS, McNel1 JS, Schrier RW. Circulation 44, 596, 1971.

Nies AS, Evans GH, Shand DG. An Heart J 85, 97, 1973.

Nigudil S, Takeshita A, Ito $N$, Imalzumi T, Matsugudu $H$, Nakamura $M$. C1tc Res 57, $244,1985$.

Nomura G, Ara1 S, Uno D, Shimao M, Takata M, Takabatake T, Hattor1 N. Remal Phystol 1, 132, 1978.

Nordlander $M$, DLBona $G F$, Ljung $B$, Yao $T$, Thorén P. Eur J Pharmacol $113,25,1985$.

Norman RA, Enobakhare JA, DeClue JW, Douglas BH, Guyton AC. Am J Physiol 234, R98, 1978.

Nutze DL, Andresen MC, Torres LA. J Pharmacol Exp Ther 239, 303, 1986.

0'Connor DT, Barg AP, Duchin KL. J Clin Pharmaco1 22, 187, 1982.

Ohlstein EH, Zabo-Potapovich B, Berkowitz BA. J Pharmacol Exp Ther $299,433,1984$.

Okamoto K, Aok1 K. Ipn Circ J 27, 282, 1963.

Ollver JA, Sclacca RR, Cannon PJ. Am J Physlo1 236, 11427, 1979.

Oliver JA, Siclacca RR, Gannon PJ. Hypertension 5, 166, 1983.

Orlowsk1 M, ML zoguchi H, W11k S. J Pharmacol Exp Ther 212, 167, 1980

Osgood RW, Lamelre NH, Jorkin MI, Stein JH. Am J Physiol 232, F92, 1977 .

Ott CE, Marchand GR, Dlaz-Buxo JA, Knox FG. Am J Physto1 231, 235, 1976.

Pafllard F, Lantz $B$, Leviel F, Ardalllow R. Am J Nephrol 6 (supp1 2), $40,1986$.

Pamani MB, Huot S, Buggy $J$, Clough D, Haddy F. Hypertenston 3 (suppl 11), 96, 1981 .

Pendleton RG, Samler L, Kaiser C, Ridley PT. Eur J Pharmacol 51, 19, 1978.

Pérez JE, Borda L, Schuchletb R, Henry PD. J Pharmacol Exp Ther 221, $609,1982$.

Perrot K, Maurer R, Engel G. 9th Int Congress Pharnacol, London, abstr 
$907 \mathrm{P}, 1984$.

Philipp Th, D1stler A, Cordes U. The Lancet $\mathbf{H}^{2}, 959,1978$.

Redran $D_{*}$ Thon $S$, Hughes $A$, Hasaan $S$, Sever $P$. 2nd Eur Neeting on Hypertension, abstr 436, 1985.

Reed BV, Tuma RF. C1in Exp Theor Pract A8, 963, 1986.

Reubi FC. Proc Soc Exp B1.01 Med 73, 102, 1950.

Richer C, Doussau MP, Giudice11i JF. Hypertension 5, 312-320, 1983 .

Roman RJ, Cowley Aw, Am J Physiol 248, E199, 1985.

Saeed $M$, Holtz J, Elsner D, Bassenge E. Eur J Pharr 94, 149, 1983.

Salgado HS, Krieger EM. Am J Physiol 234, H552, 1978.

Salvetti A, Lenonetti G, Bernini GP, Rupoli L, Lucarini AR, Sanglorgio P, Maro M, Di Stratis P, Zanchetti A. Am J Nephrol 6 (suppl 2), $45,1986$.

Salzmann $R$, Bürki $H$, Chu $D$, Clark $B$, Marbach $P$, Marksteln $R$, Reinert H, Slegl H, Waite R. Arzneim Forsch 29, 1843, 1979.

Sawyer R, Warnock P, Docherty JR. J Cardiovasc Pharnacol 7, 809, 1985. Schalekamp MADH. Prog Pharmacol 5, 69, 1984.

Schalekamp MADH, Man in 't Veld AJ, Wenting G.J. J Hypert 3, 97, 1985.

Schrier RW, Llebernan R, Ufferman RG. J Clin Invest 51, 97, 1972.

Scott EM. J Pharmacol Exp Ther 233, 801, 1985.

Scott EM, Williams, EK. Br I Pharnacol 77, 325P, 1982,

Sesoko S, Pegram BL, Frohlich ED. Cl in Exp Theor Pract A6, 979, 1984.

Seymour AA, Blaine EH. Prostaglandins. Leukotr Med 10, 349, 1983.

Shibouta Y, Nishikawa K, Kukuchf S, Shimamoto K. Eur J Pharmacol 53, $201,1979$.

Stith TL, Hutchins PM. Hypertension 1, 508, 1979.

Smits JFM, Van Essen H, Struyker Boudler HAJ. Naunyn SchmLedeberg's Arch Pharmacol 309, 13, 1979.

Smits JFM. Thesis, Maastricht, 1980.

Smits JFM, van Essen $H$, Struyker-Boudier HAJ. J Pharmacol 32, 139 , 1980 .

Smits JFM, Van Essen H, Struyker Boudier HAJ. I Pharmacol Exp Ther $215,221,1980 \mathrm{~b}$.

Smits JFM, Coleman TG, Smith TL, Kasbergen CM, Van Essen H, Struyker Boudler HAJ. J Cardiovase Pharmaco1 4, 903, 1982.

Smlts JFM, Kasbergen CM, Van Essen H, Kleinjans JCS, Struyker Boudier HAJ. Am $J$ Physiol 244, H304, 1983.

Smits J, Hofbater $K$, Fuhrer $W$, Struyker Boudier H. Proceedings 9 th Int Congr of Pharmacology, 43, 1569, 1984.

Smits JFM, Struyker Boudier HAJ. Prog Pharmacol 5, 39, 1984.

Smits JEM, Struyker Boudier HAJ. J Pharanacol Ekp Ther 232, 845, 1985.

Solts JFM, Th1jssen HHH. In: Rate-controlled drug admlnistration and action, (ed: HAJ Struyker Boudier), ch 4, P 83, 1986.

Strandhoy JW, Schnelder EG, WLl11 LR, Beck NP, Davis BB, Knox FG. An $J$ Physiol 226, 1015, 1974.

Struyker Boudier HAJ, Snits JFM, Van Essen H. C1in Sc1 56, 163, 1979.

Struyker Boudier HAJ. In: Drug destgn (ed: EJ Arléns). Acadentlc Press, New York, 1980, p 146.

Struyker Boudier HAJ, Evenwe1 RT, Smits JFM, Van Essen H. C1in Sct 62, $589,1982$.

Struyker Boudier HAJ, SmLts JEM, Klelnjans JCS, Van Essen H. Clin Exp Hypert 5A, 209, 1983.

Struyker Boudier HAJ, Van Essen H, Smits JFM. Eur J Pharmacol 95, 151, 1983. 
Struyker Boudler HAJ. In: Handbook of hypertension. Vol. 3" Pharmacology of anthypertenslve drugs (ed: PA Van Zwieten). Elsevier Publishers Company, Amsterdam, 1984, p 46.

Struyker Boudier HAl, Verwoort-Peters HTM, Rousch MM, Salts JFM, Thijsgen HHW. Life Sci 38, 137, 1986.

Struyker Boudier HAJ, Wervoort-Peters HT, Rousch MJ, Thijssen th, Sintes JFM. Fed Proc 43, 452, 1984.

Sugawara $R$, Takami. $N$, Meamura $S$, Miwa M, Ozaki M. Eur J Pharmacol 62, 287, 1.980.

Swartz S, W111ams G. J C1in Invest 65, 1257, 1980.

Swartz SL, WL1Llans GH. Am J Cardiol 49, $1405,1982$.

Takata Y, Hutchinson IS. Clin Exp Hypert AS, 827, 1983.

Tarazi RC, Dustan HP, Fröhlich. Circulation 41, 709, 1970.

Tarazi RC, Dustam AP. Am J Cardiol 29, 633, 1972.

Taylor FM, Cameron D, Eden RJ, FLelden R, Owen DAA. J Cardlovasc Pharmacol 3, 337, 1981 .

Traube L. Gesammelte Be1trage zur Pathologle und Physiologie. Vol 2, Hirschwald, Ber1in, 1871, pp 290.

U1rych M, Frohlich ED, Dustan HP, Page IH. Circulation 37, 411, 1968.

Van Baak MA, Kho TL, Thljssen H, Rahn KH. Eur J Clin Pharmacol 23, $377,1982$.

Van Baak MA, Struyker Boudier HAJ, Smits JFM. Clin Exp Hypert A., 1, 1985.

Van Boom MP, Saxena PR. Arch Int Pharmacdyn 264, 96, 1983.

Van Meel JCA, Timmermans PBMWM, Van Zwieten PA. Eur J Pharmacol 92, $27,1983$.

Van Zwieten PA, van Meel JCA, Thmermans PBMWM. Hypertension 5, 8, 1983.

Vaughan ED, Caxey RM, Pead MJ, Akerly JA, Ayers CR. Circ Res 42, 376, 1978.

Ventura HO, Messerli FH, Frohlich ED, Korbin I, Oligman W, Dunn F, Carey RM* Circulation 69, $1142,1984$.

Verbeuren $T J$, Laekeman G, Majchrowic B, Jordaens FH, Zonnekeyn LL, Herman AG. I Pharmacol Exp Ther 233, 801, 1985.

Vidrio $H$, Tena I. Clin Pharmacol Ther 28, 587, 1980.

Vlachakis ND. I Clin Pharmacol 19, 20, 1980.

Wallenstein $S$, Zucker CL, Fleiss $\mathbb{J}$. Circ Res 47, 1, 1980.

Wasserman $K$, Huss $R$, Kullmann R. Naunyn Schmledeberg; s Arch Pharmacol $312,77,1980$.

Watklns BE, Davis Jo, Lahmelster TE, Freeman RH. Clrc Res 39, 847, 1976.

Webb RC, Bohr DF. Am Heart J 102, $251,1981$.

Weber MA, Drayer JIM. Kidney Int $18,686,1980$.

Weber MA, Purdy RE, Hurlbut DF. In: Frontlers in hypertension research (eds: Laragh JH, Buhler FR, Seldin Dw). Springer Verlag, New York, 1981, pp 462 .

Wendling MG, DeGraaf GL, DuCharme DW. Clin Exp Hypert 1, 521, 1979.

Hikstrand $J$, Trimarco B, Buzzetti G, Rlcclardell1 B, De Luca N, Volpe M, Condore111 M. Acta Med Scand 672, 105, 1983.

Wilfert B, Timmermans PBMWM, Van Zwteten PA. J Pharmacol Exp Ther $221,762,1982$.

Wills LR, Ludens JH, Willamson HE. Proc Soc Exp Blol Med 1.28, 1069, 1968.

Vilkinson R. Drugs 23, 195, 1982. 
Wong $\mathrm{PC}, \mathrm{Z} 1$ jwmerman $\mathrm{BG}$. C1in Se1 61, 553, 1981 .

Worcel $M$, Salag $B$, Chevillard C. TIPS $1,136,1980$.

Yokoyama S, Kaburagi T. J Cardiovasc Pharmaco1 5, 67, 1983.

Yun J, Kelly G, Bartler FGC, Smith H. Circ Res 40, 459, 1977.

Zacest $R$, Gilmore E, Koch-Weser J. New Engl J Med 286, 617, 1972.

Zerbe GD. Commun Stat Theor Met A8, 191, 1979.

Zimerman BG, Mommen C, Kraft E. Proc Soc Exp Blol Med 164, 459, 1980 .

Zimpfer M, Sit SP, Vatner SE. Circ Res 48, 400, 1981.

Zins GR. In: Recent advances in renal physlology and pharmacology (eds.: GM Farelli, LG Wenon). University Park Press, Baltimore, $1974, \mathrm{p} 165$. 

Hubert N.M.W. Nievelstein werd op 16 jull 1954 te Kerkrade geboren. Zifn ABS-B opleiding volgde hij an het Antonius Doctor College te Kerkrade, war in 1972 het diploma behald werd.

In hetzelfde jaar ging hij wiskunde studeren aan de Katholleke Universiteit te Nifmegen.

In 1974 veranderde hij van studierichting en begon hij san dezelfide universiteit zijn studie scheikunde.

Het kandidaatsexamen $\left(S_{2}\right)$ werd afgelegd in 1978 .

In 1981 legde hif het examen MO-B scheikunde met goed gevolg af. Vervolgens werd het doctoral examen schelkunde met is hoofdvakken blochemie (onder lelding van prof.dr. H. Hoenders en dr. J. Blndels) en farmacochemie Conder leiding van prof.dr. J. van Rossum; practische stage bij Organon BV te Oss onder leiding van drs. A. Coert en dr. J. van der Vles) afgelegd in jun 11983.

Vanaf juni 1983 tot maart 1987 is hij als wetenschappelijk asslstent in dienst van de Nederlandse Organisatfe voor Zulver Wetenschappelijk onderzoek verbonden geweest aan de vakgroep farmacologie (hoofd: prof.dr. H.A.J. Struyker Boudier) van de Rijksuniversltelt Limburg te Maastricht.

Sinds 1 mart 1987 is hif in dienst van Duphar BV te Weesp en werkzaam op de afdeling farmacologie. 

LIST OF PUBLICATIONS

Fu11 papers

1. HAJ Struyker Boudier, HNM Nievelsteln, H van Essen, JFM Smits. Calcium antagonists: systemic and reglonal hemodynamic effects in consclous spontaneously hypertensive rats (SHR). J Hypertension 2 (suppl 3), 527-529, 1984 .

2. A Coert, H Nievelsteln, HJ Kloosterboer, P Loonen, J van der Vies. Effects of hyperprotactinemia on the accessory sexual organs of the male rat. The Prostate 6, 269-276, 1985.

3. MA Blankenstein, J Bolt-de Vries, A Coert, H Nlevelstein, FH Schröder. Effect of long-term hyperprolactinemia on the prolactin receptor content of the rat ventral prostate. The Prostate 6, $277-283,1985$.

4. HMMW Nievelstein, H van Essen, CM Tyssen, JFM Smfts, HAJ Struyker Boudier. Systemic and reglonal hemodynamic actions of calclum entry blockers in conscious spontaneously hypertensive rats. Eur $\mathrm{J}$ Pharmaco1 113, 187-198, 1985.

5. HMW Nievelstein, H van Essen, R Hornsveld, HAJ Struyker Boudter, JFM Snits. Effects of the renal vasodilator prodrug CGP $22979 \mathrm{~A}$ and 1 ts parent compound CGP $18137 \mathrm{~A}$ on renal and central hemodynamics in conscious, spontaneously hypertensive rats. J Pharmacol Exp Ther 235, 778-782, 1985 .

6. HMM Mievelsteln, CM Tyssen, JFM Smits, HAJ Struyker Boudier* Reglonal hemodynamic effects of the beta-adrenoceptor blockers tertatolol and propranolol in conscious, spontaneously hypertensive rats. Arch Int Pharmacodyn 282, 118-129, 1986.

7. HAJ Struyker Boudier, H van Essen, HNMW NLevelsteln, JFM Smfts. The role of baroreflex activations in the reglonal hemodynamic effects of the beta blockers tertatolol and propranolol in conscious, spontaneously hypertensive rats. An J Nephrol 6 (suppl 2), $25-29,1986$. 
8. HAJ Struyker Boudier, JCS Rleinjans, LML le Noble, HMN Niteve1steln, JPM Srits. Rate-controlled cardiovascular drug administration and action. Rate-controlled drug adninistration and action. (ed: HA.J Struyker Boudier). CRC Press, Boca Raton (F1), USA, 1986, pp $171-203$.

9. H Nievelstefi, M Schaefer, H Struyker Boudier, J Smits. The effect of baroreflex activation on reglonal hemodynamics in consclous normotenslve rats. J Hypertension. In press, 1.987.

10. H.NM NLevelstedn, G Tyssen, I Smlts, H Struyker Boudier. Effects of electrical stimulation of the median raphe nucleus on the reglonal heradynamics in spontaneously hypertensive rats. (In preparation).

11. H Nevelstein, C Tyssen, J Solts, H Struyker Boudier. Long-term reglonal hemodynamic effects of the beta-blockers tertatolol and propranolol in consclous, spontaneously hypertensive rats (In preparation).

1.2 Nievelsteln, C Tyssen, J Smits, H Struyker Boudfer. Long-term reglonal hemodynamic effects of the renal vasodilator prodrug CGP $22979 \mathrm{~A}$ and its parent compound CGP $18137 \mathrm{~A}$ in consclous, spontaneously hypertensive rats (In preparation).

\section{Abstracts}

1. H Mlevelstein, A Coert, J van der Vies, MA Blankenstein, J Bolt-de Vries. Effects of hyperprolactinemia on the accessory sexual organs of the male rat. Proc Fed Verg Med Wet Ver 1983.

2. HNMW Nievelstein, JFM Smits, HA.J Struyker Boudier. Effects of nifediplne and hydralaztne on reglonal blood flows in consctous, spontaneously hypertensive rats (SHR). Pharmaceut Wbl. 5, 264, 1983.

3. H Nevelstedn, C Tyssen, H Struyker Boudler, I Smits. Differentlal baroreflex modulation of reglonal responses to vasodilator drugs in consclous, spontaneously hypertensive rats (SHR). Pharmacent Wb1 $6,226,1984$.

4. H Nevelsteln, H van Essen. Effects of calclum entry blockers on the systemilc and reglonal hemodynamics in consclous, spontaneously hypertensive rats (SHR). Naunyn Schmiedeberg"s Arch Pharmacol 325 (supp1), 174, 1984.

5. H Nlevelsteln, H van Essen, JE Smits, HA Struyker Boudier. Systeic and reglonal hemodynamic action of calctum entry blockers in the consclous SHR. Fed Proc 43, 550, 1984.

6. H Nevelstein, C Tyssen, H Struyker Boudier, J Smits. Role of baroreflex in regional hemodynamlc effects of nifedipine and PY 
108-068 in consclous SHR. IUPHAR 9th, Int Congr Pharadeol, London, 1998,1984 .

7. H Struyker Boudier, H Nievelstefn J Smits. Reglonal hemodynamic effects of the beta blocker propranolol and tertatolol in the consclous, spontaneously hypertenslve rats (SGR). IUPHAR 9 th int Congr Pharmacol, London, 548, 1984 *

8. HWHW Nievelstein, CM Tyssen, H van Essen, JFM Smits, HAJ Struyker Boudier. The role of the baroreflex in the reglonal vascular respanses of the beta blockers tertatolol and propranolol in conscious SHR. Pharmaceut Wb1 $7,233,1985$.

9. H Nievelstein, C Tyssen. Reglonal vascular responses to electrical stimulation of the spinal cord in pithed SHR. Naunyn Schmiedeberg"s Arch Pharmacol 329 (suppI), 254, 1985.

10. H Nievelstein, H van Essen, H Struyker Boudier, J Smits. Acute systenic hemodynamic effects of the renal vasodilator drug CGP 22 979 A in SHR. Fed Proc 44, 1644, 1995.

11. H Nievelsteln, C Tysisen, H van Essen. The role of the baroreflex in the acute regional vascular effects of the beta blockers propranolol and tertatolol tn consclous SHR. Naunyn Schmladeberg's Arch Pharmacol 332 (suppl), 231, 1986.

12. H Struyker Boudier, H Nievelsteln, C Tyssen, J Smits. Hemodynamic effects of electrical stimulation of the nucleus medianus raphes (NMR) in the rat. Fed Proc 45, 744, 1986.

13. H Nievelstein, M Schaefer, H Struyker Boudier, J Smits. The effect of baroreflex activation on reglonal hemodynamics in consclous narmotensive rats. Ilth Sci Meeting Int Soc Hypert, Heldelberg, $745,1986$.

14. HMNW Nievelstein, JFM Smits, HAJ Struykex Boudier. Long-term hemodynamic effects of the renal vasodilator CGP $22979 \mathrm{~A}$ in consctous SHR. Third European Meeting on Hypertenston, Milan, Italy, in press. 